\title{
Laboratory Evaluation of the Hydrogen Sulfide Gas Treatment Approach for Remediation of Chromate-, Uranium (VI)-, and Nitrate-Contaminated Soils
}

E. C. Thornton

M. A. Baechler

M. A. Beck

Westinghouse Hanford Company

J. E. Amonette

Pacific Northwest Laboratory

Date Published

August 1994

Prepared for the U.S. Department of Energy In Situ Remediation Integrated Program

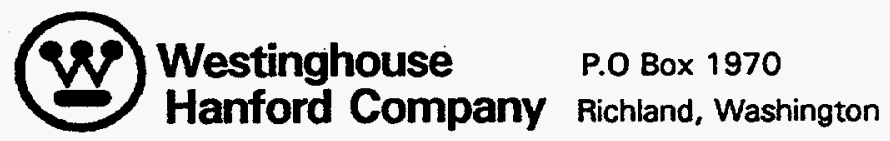

Hanford Operations and Engineering Contractor for the

U.S. Department of Energy under Contract DE-AC06-87RL10930 


\section{DISCLAIMER}

This report was prepared as an account of work sponsored by an agency of the United States Government. Neither the United States Government nor any agency thereof, nor any of their employees, make any warranty, express or implied, or assumes any legal liability or responsibility for the accuracy, completeness, or usefulness of any information, apparatus, product, or process disclosed, or represents that its use would not infringe privately owned rights. Reference herein to any specific commercial product, process, or service by trade name, trademark, manufacturer, or otherwise does not necessarily constitute or imply its endorsement, recommendation, or favoring by the United States Government or any agency thereof. The views and opinions of authors expressed herein do not necessarily state or reflect those of the United States Government or any agency thereof. 


\section{DISCLAIMER}

Portions of this document may be illegible in electronic image products. Images are produced from the best available original document. 


\section{RELEASE AUTHORIZATION}

Document Number: WHC-EP-0694

$\begin{array}{ll}\text { LABORATORY EVALUATION OF THE HYDROGEN SULFIDE GAS } \\ \text { Document Title: } & \text { TREATMENT APPROACH FOR REMEDIATION OF CHROMATE, } \\ \text { URANIUM }(V I), \text { AND NITRATE-CONTAMINATED SOIL }\end{array}$

Release Date: $\quad 8 / 24 / 94$

* * * * * * * * ***** *

This document was reviewed following the procedures described in WHC-CM-3-4 and is:

APPROVED FOR PUBLIC RELEASE

****************

WHC Information Release Administration Specialist:

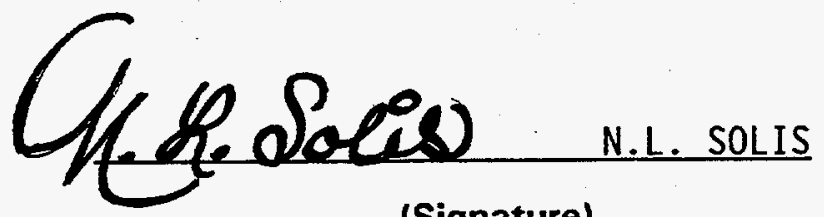

(Signature)

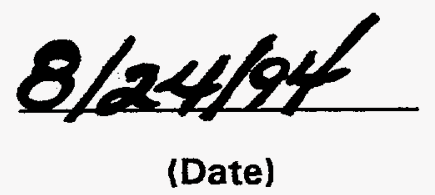




\begin{abstract}
Bench-scale soil treatment tests were conducted as part of an effort to develop and implement an in situ chemical treatment approach to the remediation of metal and radionuclide contaminated soils through the use of reactive gases. These tests involved three different soils contaminated with $\mathrm{Cr}(\mathrm{VI})$ and $\mathrm{U}(\mathrm{VI})$ at the $200 \mathrm{ppm}$ level. Treatment of the soils was performed using $100 \mathrm{ppm}$ and $2000 \mathrm{ppm}$ concentrations of hydrogen sulfide in nitrogen applied at a flow rate of 2400 to $2500 \mathrm{~mL} / \mathrm{min}$ through packed columns. Treatment duration was adjusted such that the mole ratio of $S:(C r+U)$ lies in the range from 7 to 10 . The soil columns were leached with groundwater or deionized water subsequent to treatment to determine the degree of immobilization of the contaminants. In general, $>90 \%$ immobilization of chromium and $>50 \%$ immobilization of uranium was achieved. Leach test results indicate that the treatment process is irreversible for chromium but partially reversible for uranium. The degree of treatment effectiveness and the extent of reversibility observed for uranium indicates that immobilization for this contaminant is more readily achieved in organic-rich soils. This observation is ascribed to the reducing nature of organic matter.
\end{abstract}

Additional tests were also conducted with soils contaminated to the $5000 \mathrm{ppm}$ level with nitrate. Nitrate was not found to interfere significantly with treatment of the contaminants. Nitrite was observed in the leachate samples obtained from tests with an organic-rich soil containing clay, however. Leachate chemistries suggested that no other significantly hazardous byproducts were generated by the treatment process and that soil alteration effects were minimal. Test results also suggested that treatment effectiveness is somewhat lower in very dry soils but still able to immobilize chromium and uranium to an acceptable degree.

Results of these testing activities indicate that the concentration of hydrogen sulfide in the gas mixture is not a limiting factor in treatment as long as a sufficient volume of the mixture is delivered to the soil to achieve a mole ratio of hydrogen sulfide to contaminant of at least 10 . This is an important consideration since hydrogen sulfide is a toxic gas and will be much more acceptable for use in soil treatment if applied in low concentration mixtures with an inert carrier gas. 


\section{ACKNOWLEDGMENTS}

This work is funded by the Office of Technology Development, within the U.S.

Department of Energy's Office of Environmental Restoration and Waste Management, under the In Situ Remediation Technology Development Integrated Program. 


\section{CONTENTS}

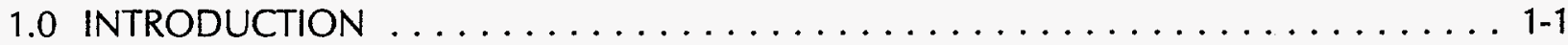

2.0 EXPERIMENTAL APPROACH AND OBJECTIVES $\ldots \ldots \ldots \ldots \ldots \ldots \ldots \ldots \ldots$

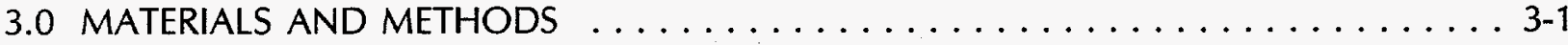

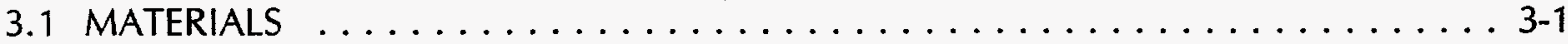

3.2 GAS TREATMENT AND COLUMN LEACH TESTS $\ldots \ldots \ldots \ldots \ldots \ldots \ldots \ldots \ldots . . \ldots . . \ldots$

3.3 ANALYTICAL METHODS AND QUALITY CONTROL REQUIREMENTS $\ldots \ldots \ldots$

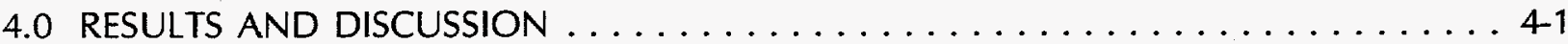

4.1 GAS TREATMENT AND SOIL COLUMN LEACH TESTS . . . . . . . . . 4-1

4.1.1 Hanford Site Soil Tests . . . . . . . . . . . . . . . . . . . . . . 4-1

4.1 .2 Sandia Soil Tests . . . . . . . . . . . . . . . . . . . . 4-10

4.1 .3 Fernald Soil Tests ... . . . . . . . . . . . . . . . . . . 4-11

4.2 SUMMARY OF TESTING RESULTS AND COMPARISON WITH

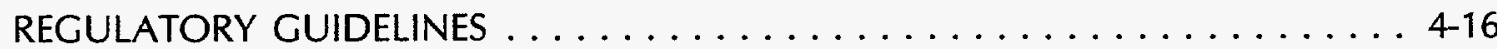

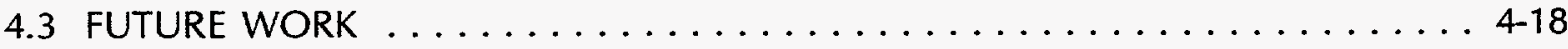

5.0 CONCLUSIONS $\ldots \ldots \ldots \ldots \ldots \ldots \ldots \ldots \ldots \ldots \ldots \ldots \ldots \ldots \ldots \ldots \ldots \ldots \ldots \ldots$

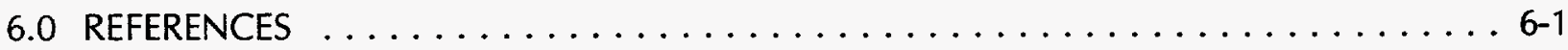

\section{APPENDIXES:}

A. LEACHATE ANALYTICAL DATA AND SOIL MOISTURE CONTENTS . . . . . . A A-1

B. ASSESSMENT OF CHROMIUM RECOVERY FROM SOILS . . . . . . . . . . . B-1

C. ASSESSMENT OF URANIUM RECOVERY FROM SOILS . . . . . . . . . . . C-1

\section{FIGURES:}

1. Eh-pH Diagram for the Chromium System at $25^{\circ} \mathrm{C} \ldots \ldots \ldots \ldots \ldots \ldots \ldots \ldots \ldots$

2. Schematic Illustration of Gas Treatment System . . . . . . . . . . . . . . . . 3-4

3. Schematic Illustration of Column Leaching System . . . . . . . . . . . . . . 3-5

4. $\mathrm{Cr}(\mathrm{VI})$ Concentrations of Leachate Samples for Hanford Site Soil

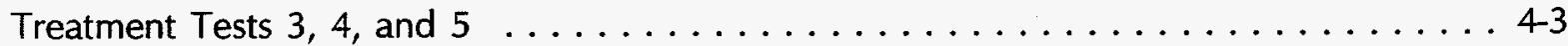

5. Uranium Concentrations of Leachate Samples for Hanford Site Soil

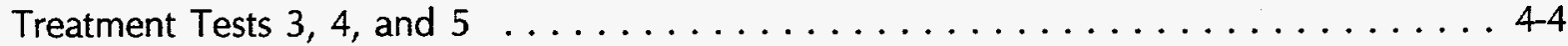

6. $\mathrm{Cr}(\mathrm{VI})$ Concentrations of Leachate Samples for Hanford Site Soil

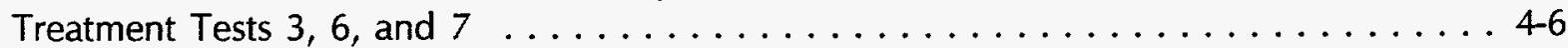

7. Uranium Concentrations of Leachate Samples for Hanford Site Soil

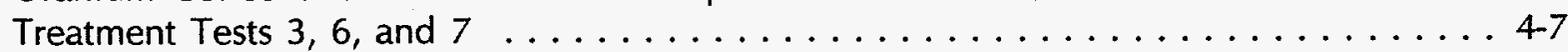

8. $\mathrm{Cr}(\mathrm{VI})$ Concentrations of Leachate Samples for Hanford Site Soil

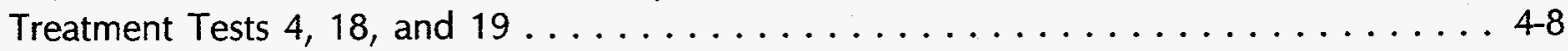

9. Uranium Concentrations of Leachate Samples for Hanford Site Soil

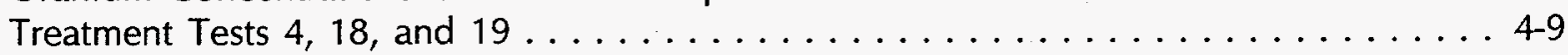

10. $\mathrm{Cr}(\mathrm{VI})$ Concentrations of Leachate Samples for Sandia Soil

Treatment Tests 10, 11, and 12 


\section{CONTENTS (Continued)}

\section{FIGURES:}

11. $\mathrm{Cr}(\mathrm{VI})$ Concentrations of Leachate Samples for Fernald Soil

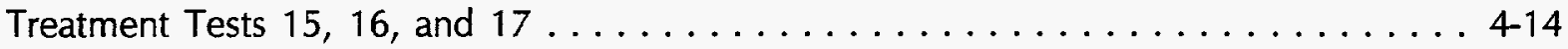

12. Uranium Concentrations of Leachate Samples for Fernald Soil

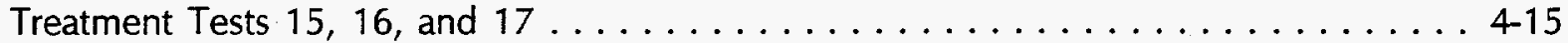

13. Proposed Injection and Extraction Well Pattern Configuration . . . . . . . . . 4-19

\section{TABLES:}

1. Test Matrix

2. Summary of $\mathrm{H}_{2} \mathrm{~S}$ Treatment Parameters and Results of Hanford Site

Soil Treatment Tests . . . . . . . . . . . . . . . . . . . . . 42

3. Summary of $\mathrm{H}_{2} \mathrm{~S}$ Treatment Parameters and Results of Sandia

Soil Treatment Tests . . . . . . . . . . . . . . . . . . . . . . . 4 411

4. Summary of $\mathrm{H}_{2} \mathrm{~S}$ Treatment Parameters and Results of Fernald

Soil Treatment Tests . . . . . . . . . . . . . . . . . . . . . . . . 4-13 


\subsection{INTRODUCTION}

Contamination of soils by metals and radionuclides is an important environmental concern in private industry and at government facilities. Conventional approaches to site remediation have generally emphasized either site isolation using physical barriers or removal of contaminated media to offsite locations. Limitations of these approaches include uncertainties associated with the long-term isolation capabilities of engineered barriers, exposure of workers during site excavation or pumping, and the increasing scarcity and long-term liabilities associated with offsite disposal (Ghassemi 1988).

These considerations have generated interest in the development of a variety of in situ remediation technologies, including in situ chemical treatment or immobilization (e.g., EPA 1985, EPA 1990, and Smith 1985). This approach should be especially effective for metals and radionuclides, whose solubility or sorption characteristics are strongly dependent on concentrations of associated ligands or the redox and $\mathrm{pH}$ characteristics of the environment. Development of the in situ chemical treatment approach, however, has been largely limited to small-scale applications. Solid treatment agents, for example, have been utilized to remediate relatively small surface sites consisting of metal or radionuclide-contaminated soils (Czupyrna et al. 1989, Kim 1990, and Browman and Spalding 1984).

The feasibility of the in situ chemical treatment approach to larger scale remediation activities involving soils would be enhanced if an efficient approach were identified for the introduction of effective treatment agents. Additionally, recovery of unreacted agents is desirable or necessary. Mixing or injection of solid agents into contaminated soils, perhaps in combination with cements or grouts, has been suggested. This approach is likely to be expensive for larger waste sites, however, and will result in significant disturbance to the site. Injection of solutions containing treatment agents is also a viable approach but would generally require the installation of a leachate collection system.

The use of chemical treatment gases is an alternative that offers the advantage of ease of introduction and control and also the potential for removal of unreacted agent from the soil at the completion of treatment. It is also anticipated that this approach will be less costly than many conventional approaches for soil remediation and will not result in secondary wastes requiring disposal.

Initial results of laboratory testing activities undertaken to evaluate the treatment of chromatecontaminated soils using reactive gases have been presented in Thornton et al. (1991). That work demonstrated that hydrogen sulfide is very effective in reducing and immobilizing hexavalent chromium. The present study represents an effort to verify the approach more fully and to better evaluate the effect of major parameters on the effectiveness of the treatment process.

Hexavalent chromium and uranium were selected as target contaminants for this study because they are of widespread environmental concern and amenable to gas treatment. Chromium occurs in solution primarily in the hexavalent oxidation state and is distributed between the anionic species $\mathrm{CrO}_{4}{ }^{2-}$ or $\mathrm{HCrO}_{4}^{2-}$ (Figure 1). Addition of a suitable reducing agent will lower the oxidation potential (Eh) of the system and thus reduce chromium to the trivalent state, which is relatively insoluble except under strongly acidic conditions. Thus, reduction of

hexavalent chromium will serve to eliminate the toxicity of the contaminant by converting it to 


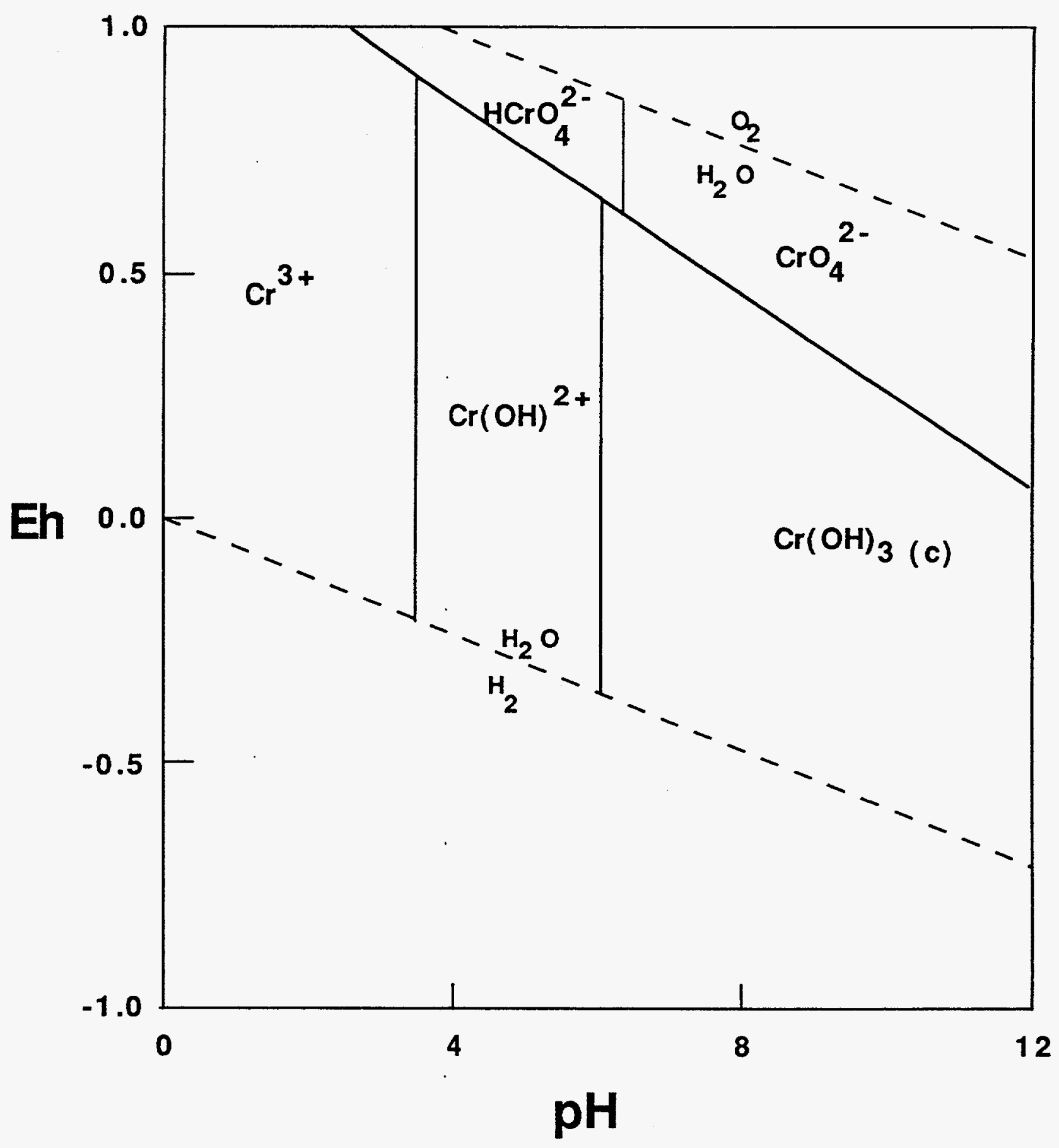

Figure 1. Eh-pH Diagram for the Chromium System at $25^{\circ} \mathrm{C}$ (WHC 1993a). Boundaries are displayed for log activities of dissolved species $=-6$ and for unit activities of solids and gases. Precipitated $\mathrm{Cr}(\mathrm{III})$ is represented by solid $\mathrm{Cr}(\mathrm{OH})_{3(\mathrm{c})}$. 
the relatively harmless trivalent oxidation state and should also result in precipitation of the reduced chromium, especially if the $\mathrm{pH}$ of the environment is neutral to somewhat basic. Uranium behaves in a manner somewhat similar to chromium, also being soluble in the hexavalent oxidation state and less so in the tetravalent state.

Three different soil types were utilized in this study in order to determine if variations in sediment chemistry will result in significant variations in treatment effectiveness. In addition, variations in soil moisture content and nitrate content were examined. Of particular importance was the use of relatively dilute hydrogen sulfide concentrations $(2000 \mathrm{ppm}$ and $100 \mathrm{ppm}$ in nitrogen) in this study, since the safety hazards associated with use of this agent are significantly reduced at low concentrations. 
WHC-EP-0694

$1-4$ 


\subsection{EXPERIMENTAL APPROACH AND OBJECTIVES}

Soil column tests were conducted in the course of this work to evaluate the viability of gas treatment of contaminated soil in the unsaturated zone and, in particular, to determine if adequate treatment and immobilization of chromium and uranium can be achieved using dilute mixtures of hydrogen sulfide in an inert carrier gas (nitrogen). The approach utilized in this study consisted of packing the contaminated soil sample into a column and passing a known concentration of the treatment gas through the column at a specified flow rate. Each test was conducted for the period of time required to deliver a specified amount of hydrogen sulfide to the soil, expressed as a molar ratio of hydrogen sulfide to contaminant constituents. The packed column was subsequently leached with deionized water or groundwater at a constant flow rate, and the leachate solutions were analyzed for the contaminants and other constituents. Column leach tests were also conducted with uncontaminated/untreated, uncontaminated/treated, and contaminated/untreated soils as controls. Mass balance considerations were then employed to determine the fraction of each contaminant constituent reduced and immobilized during treatment. Specific information and procedures associated with these tests are presented in WHC (1993b).

The contaminants studied in the tests included hexavalent chromium, hexavalent uranium, and nitrate. These are constituents having an oxidized nature and thus are candidates for treatment with hydrogen sulfide, a reducing gas. In particular, chromium and uranium are contaminants of concern at government facilities. Nitrate is also frequently present in contaminated soils and is often associated with chromium and uranium. Nitrate may affect the treatment process through interaction with hydrogen sulfide and has the potential of being reduced to nitrite, an undesirable byproduct.

The primary performance goal for soil treatment is to demonstrate that the fraction of chromium or uranium that is leachable following treatment is below the level of concern, as defined by regulatory protocol (e.g., Toxic Characteristic Leach Procedure). The soils were contaminated at the $200 \mathrm{ppm}$ level, which is within the range of uranium and chromium contamination present at several waste sites within the U.S. Department of Energy (DOE) complex. These concentrations are about twice that of cleanup levels identified in guidance documents (e.g., Method A Cleanup Levels - Soil, Table 2 of Washington Administrative Code 173-340; Table K-1 of WHC 1988) and thus can be considered as representative of moderately contaminated soils. Therefore, $50 \%$ immobilization of these contaminants is designated as the minimum performance goal associated with this study.

Three uncontaminated soils were obtained for use in this study and are referred to as the Hanford Site soil, the Sandia soil, and the Fernald soil. These soils are associated with waste sites that are contaminated by uranium and/or chromium and thus the results obtained from this study may provide information supporting a future field demonstration. In addition, because the chemistry and mineralogy of the three soils are somewhat different, information should be gained that will allow an assessment of the impact of soil chemistry on treatment effectiveness.

Earlier proof-of-principle testing activities indicated that hydrogen sulfide concentrations of $1 \%(10,000 \mathrm{ppm})$ and $0.27 \%(2700 \mathrm{ppm})$ are effective in immobilizing hexavalent chromium at the $5 \mathrm{ppm}$ level (Thornton et al. 1991). The present study involves contamination at the $200 \mathrm{ppm}$ level, as indicated above, and gas treatment at lower hydrogen sulfide concentrations (2000 ppm and $100 \mathrm{ppm}$ ). Thus, an important objective of this work is to demonstrate that soils 
that have moderately high levels of chromium and uranium contamination can be effectively treated using relatively low concentrations of hydrogen sulfide. This is important because, while hydrogen sulfide is a highly toxic gas, the health effects are relatively moderate and temporary in nature for short-term exposure at the 100 ppm level (Sax and Lewis 1989).

The chemical reactions associated with these tests involve the reduction of the contaminant (chromium or uranium) to a lower oxidation state. The contaminant will subsequently precipitate as an oxyhydroxide solid phase. This may be illustrated for chromate by the following reaction:

$$
8 \mathrm{CrO}_{4}^{2-}+3 \mathrm{H}_{2} \mathrm{~S}+10 \mathrm{H}^{+}+4 \mathrm{H}_{2} \mathrm{O} \rightarrow 8 \mathrm{Cr}(\mathrm{OH})_{3}+3 \mathrm{SO}_{4}^{2-}
$$

Note that hydrogen sulfide is converted to sulfate in this reaction and that 3 moles of hydrogen sulfide are required to reduce 8 moles of $\mathrm{Cr}(\mathrm{VI})$ to $\mathrm{Cr}(\mathrm{III})$. Since sulfate is not generally regarded as a contaminant of concern and chromium (III) hydroxide is an insoluble and essentially nontoxic solid, it is unlikely that a significant quantity of hazardous byproducts will be generated by the gas treatment approach. Excess hydrogen sulfide may be removed from the soil by purging with nitrogen or air. The reaction equation indicates, however, that the $\mathrm{pH}$ of the soil pore water may be affected by the treatment process. This could result in the mobilization of certain constituents. It is also possible, though unlikely, that nitrate present in the soil treatment tests may be converted to nitrite. The leachate samples obtained in the tests were analyzed to evaluate changes in $\mathrm{pH}$ and to identify any undesirable reaction products generated during the treatment process.

The effect of variations in soil moisture content was also investigated. For the Hanford soil, two additional tests were performed for dry and moist soils (about 0 and $10 \%$ moisture content versus about $5 \%$ for the soil as received). This information is considered to be relevant since the reduction reaction may be mediated by moisture. That is, moisture content will determine whether reaction between the treatment gas occurs in pore space solutions or by gas/solid interaction. 
WHC-EP-0694

\subsection{MATERIALS AND METHODS}

\subsection{MATERIALS}

An uncontaminated soil sample from the Hanford formation was collected from the 100-D Area of the Hanford Site in Washington for use in the treatment tests. The sample is a medium-grained sand containing a mixture of quartz and rock fragments (basalt, granite, and metamorphics). Few particles larger than sand size were present in the soil. The inorganic carbon content of the Hanford formation soil sample is $0.255 \%\left(2.1 \mathrm{wt} \% \mathrm{CaCO}_{3}\right)$ and total carbon is $1.65 \%$ (organic carbon $=1.4 \%$, by difference). The soil has a moisture content of $5.82 \%$ (Appendix A). The sample was collected about 6 inches below the surface and contains scattered rootlets, indicating the presence of organic matter.

A second uncontaminated soil sample was provided by staff at Sandia National Laboratories in New Mexico and was collected at a location near the Chemical Waste Landfill associated with the DOE Mixed Waste Landfill Integrated Demonstration (MWLID). This soil also has a sandy character but contains pebbles and cobbles. The inorganic carbon content of the soil is $3.6 \%$ ( $30 \mathrm{wt} \% \mathrm{CaCO}_{3}$ ) and total carbon is $5.35 \%$ (organic carbon $=1.8 \%$, by difference). The soil has a moisture content of $5.59 \%$.

The third sample available for testing was obtained from staff associated with the DOE Uranium Soils Integrated Demonstration at the Fernald/Feed Materials Production Center in Ohio. This soil is a dark-colored soil having a high clay content. The inorganic carbon content of the soil is $0.12 \%\left(1.0\right.$ wt $\left.\% \mathrm{CaCO}_{3}\right)$, and total carbon is $9.8 \%$ (organic carbon $=9.7 \%$, by difference). The soil has a moisture content of approximately $16 \%$.

Deionized or distilled water and reagent grade chemicals were used in all testing activities. In addition, the leach tests conducted on the Hanford soil sample were performed using a groundwater sample collected from the Hanford unconfined aquifer (sample 3-1009 of Appendix A; collected from well $\mathrm{H} 3-2 \mathrm{C}$ on November 19, 1992, at 0830). Compressed gas cylinders containing a $1 \%$ mixture of hydrogen sulfide in nitrogen and pure nitrogen were used. Stock solutions of $\mathrm{Cr}(\mathrm{VI}), \mathrm{U}(\mathrm{VI})$, and $\mathrm{NO}_{3}{ }^{-}$were prepared from $\mathrm{Na}_{2} \mathrm{CrO}_{4}, \mathrm{UO}_{2}\left(\mathrm{NO}_{3}\right)_{2} \cdot 6\left(\mathrm{H}_{2} \mathrm{O}\right)$, and $\mathrm{NaNO}_{3}$, respectively, for use in generating contaminated soils for the column tests.

\subsection{GAS TREATMENT AND COLUMN LEACH TESTS}

The procedures and methods associated with the soil treatment tests have been fully described in WHC (1990) and WHC (1993b) and are summarized below. A test matrix that indicates major test parameters is presented in Table 1 , and test data are presented in Appendices A, B, and C.

Contaminant concentration levels associated with soils are reported as parts per million $(\mathrm{ppm})$, which is a mass $/$ mass unit of milligrams per kilogram $(\mathrm{mg} / \mathrm{kg})$. Contaminated soil was generated for use in the tests by adding $\mathrm{Cr}(\mathrm{VI}), \mathrm{U}(\mathrm{VI})$, and $\mathrm{NO}_{3}^{-}$solutions to portions of the soil samples such that $200 \mathrm{ppm}$ levels of chromium and/or uranium were achieved. Nitrate levels in 
Table 1. Test Matrix.

\begin{tabular}{|c|c|c|c|}
\hline $\begin{array}{c}\text { Test } \\
\text { number }\end{array}$ & Soil type & $\begin{array}{l}\text { Contaminants } \\
\text { added }\end{array}$ & $\begin{array}{l}\mathrm{H}_{2} \mathrm{~S} \text { treatment } \\
\text { concentration } \\
\quad(\mathrm{ppm})\end{array}$ \\
\hline 1 & Hanford & none & none \\
\hline 2 & Hanford & none & 2,000 \\
\hline 3 & Hanford & 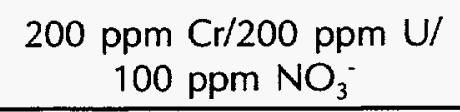 & none \\
\hline 4 & Hanford & 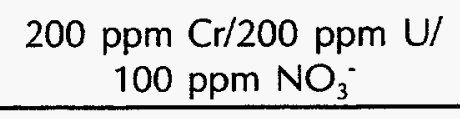 & 2,000 \\
\hline 5 & Hanford & 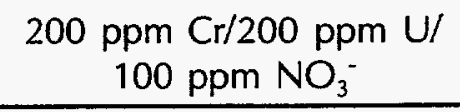 & 100 \\
\hline 6 & Hanford & $\begin{array}{c}200 \mathrm{ppm} \mathrm{Cr} / 200 \mathrm{ppm} \mathrm{U/} \\
5000 \mathrm{ppm} \mathrm{NO} \mathrm{NO}^{-}\end{array}$ & 2,000 \\
\hline 7 & Hanford & 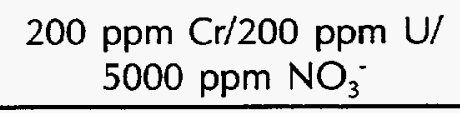 & 100 \\
\hline 8 & Sandia & none & none \\
\hline 9 & Sandia & none & 2,000 \\
\hline 10 & Sandia & 200 ppm Cr & none \\
\hline 11 & Sandia & $200 \mathrm{ppm} \mathrm{Cr}$ & 2,000 \\
\hline 12 & Sandia & $200 \mathrm{ppm} \mathrm{Cr}$ & 100 \\
\hline 13 & Fernald & none & none \\
\hline 14 & Fernald & none & 2,000 \\
\hline 15 & Fernald & 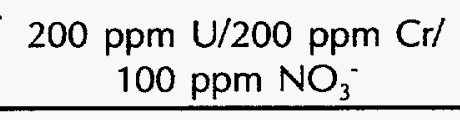 & none \\
\hline 16 & Fernald & 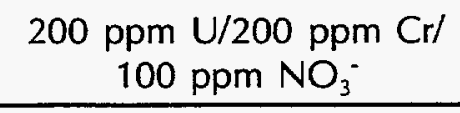 & 2,000 \\
\hline 17 & Fernald & 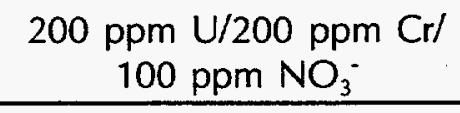 & 100 \\
\hline 18 & Hanford & 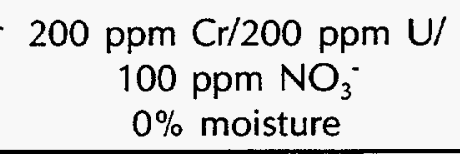 & 2,000 \\
\hline 19 & Hanford & $\begin{array}{c}200 \mathrm{ppm} \mathrm{Cr} / 200 \mathrm{ppm} \mathrm{U} / \\
100 \mathrm{ppm} \mathrm{NO}_{3}^{-} \\
10 \% \text { moisture }\end{array}$ & 2,000 \\
\hline
\end{tabular}


the soils were adjusted to about $100 \mathrm{ppm}$ or to $5000 \mathrm{ppm}$. Contaminated soils were prepared in $1 \mathrm{~kg}$ batches and mixed thoroughly to ensure homogenization (WHC 1993b). The artificially contaminated soil was then air dried at room temperature, a moisture content determination was performed, and a portion of the sample was packed into a column of known volume. The measured mass and volume of soil packed into the column, together with a determination of the particle density and moisture content of the soil, were utilized to calculate the pore volume of the column (WHC 1990). Soil mass and contaminant concentration were used to calculate the total mass of contaminants present on the soil in each column.

The components and configuration of the gas treatment system are schematically illustrated in Figure 2. This system permits delivery of a regulated, continuous flow of a mixture of the treatment gas in an inert carrier gas. Flow rates of the treatment gas and nitrogen were adjusted using the flow meters, as shown in Figure 2, to produce specified hydrogen sulfide concentrations. The length of treatment time was measured. This information, plus the known amount of contaminants in the column, permits calculation of the mole ratio of treatment gas to total contaminant constituents associated with the tests (WHC 1993b). Gas concentration units reported below as ppm refer to the volume/volume unit of microliters per liter.

As indicated in Table 1, hydrogen sulfide concentrations of $2000 \mathrm{ppm}$ and $100 \mathrm{ppm}$ were utilized for soil treatment and were prepared by mixing $1 \%$ hydrogen sulfide with pure nitrogen. A primary objective of employing these concentration values was to verify that adequate treatment can be achieved using relatively dilute concentrations of hydrogen sulfide. The treatment gas mixtures were allowed to flow through the columns at a rate of 2400 to $2500 \mathrm{~mL} / \mathrm{min}$ until a mole ratio of $\mathrm{H}_{2} \mathrm{~S}:\{\mathrm{Cr}(\mathrm{VI})+\mathrm{U}(\mathrm{VI})\}$ equal to about 10:1 was achieved (approximately 25 times the minimum required stoichiometric ratio of 3:8). The time associated with treatment was varied from 20.9 to 25.5 hours at the $100 \mathrm{ppm} \mathrm{H}_{2} \mathrm{~S}$ level and from 60 to 74 minutes at the $2000 \mathrm{H}_{2} \mathrm{~S}$ ppm level, depending on the specific combination of contaminants associated with each test. Actual molar ratios were calculated subsequent to treatment and estimated to be 7 to 8 for the Hanford tests (tests $4,5,6,7,18$ and 19), 9 to 10 for the Sandia tests (tests 11 and 12), and 9.8 for the Fernald tests (tests 16 and 17).

Gas flow rates were continuously monitored and manually adjusted during the one-hour tests (2000 ppm treatment level). Thus a high degree of confidence can be placed on having achieved mole treatment ratios very close to the calculated values and a hydrogen sulfide concentration maintained near 2000 ppm during these tests (i.e., within an uncertainty of less than $5 \%$ ). The 24-hour period required for the treatment tests at the $100 \mathrm{ppm}$ level prohibited continuous monitoring and adjustment of gas flow rates. Thus, less confidence can be placed on having achieved the calculated molar ratios and maintaining rigorous control of hydrogen sulfide concentration. It is considered that the uncertainty associated with the mole ratio value and gas concentration for the $100 \mathrm{ppm}$ treatment tests could be as much as $25 \%$.

The columns containing the gas-treated soils were subjected to leaching with deionized water or groundwater, as illustrated in Figure 3. A peristaltic pump was adjusted to provide a constant flow rate of about one pore volume per day (approximately $100 \mathrm{~mL}$ day) for the duration of the tests ( 6 days). Four leachate solutions were collected per test, weighed, filtered to $0.45 \mu \mathrm{m}$, and analyzed for $\mathrm{pH}$, hexavalent and total chromium, uranium, nitrate, and other cations and anions (Appendices A, B, and C). This information permitted an assessment to be made of the fraction of each contaminant reduced and immobilized by gas treatment and the nature of interactions between the leachate fluids, treated soils, and contaminants. 


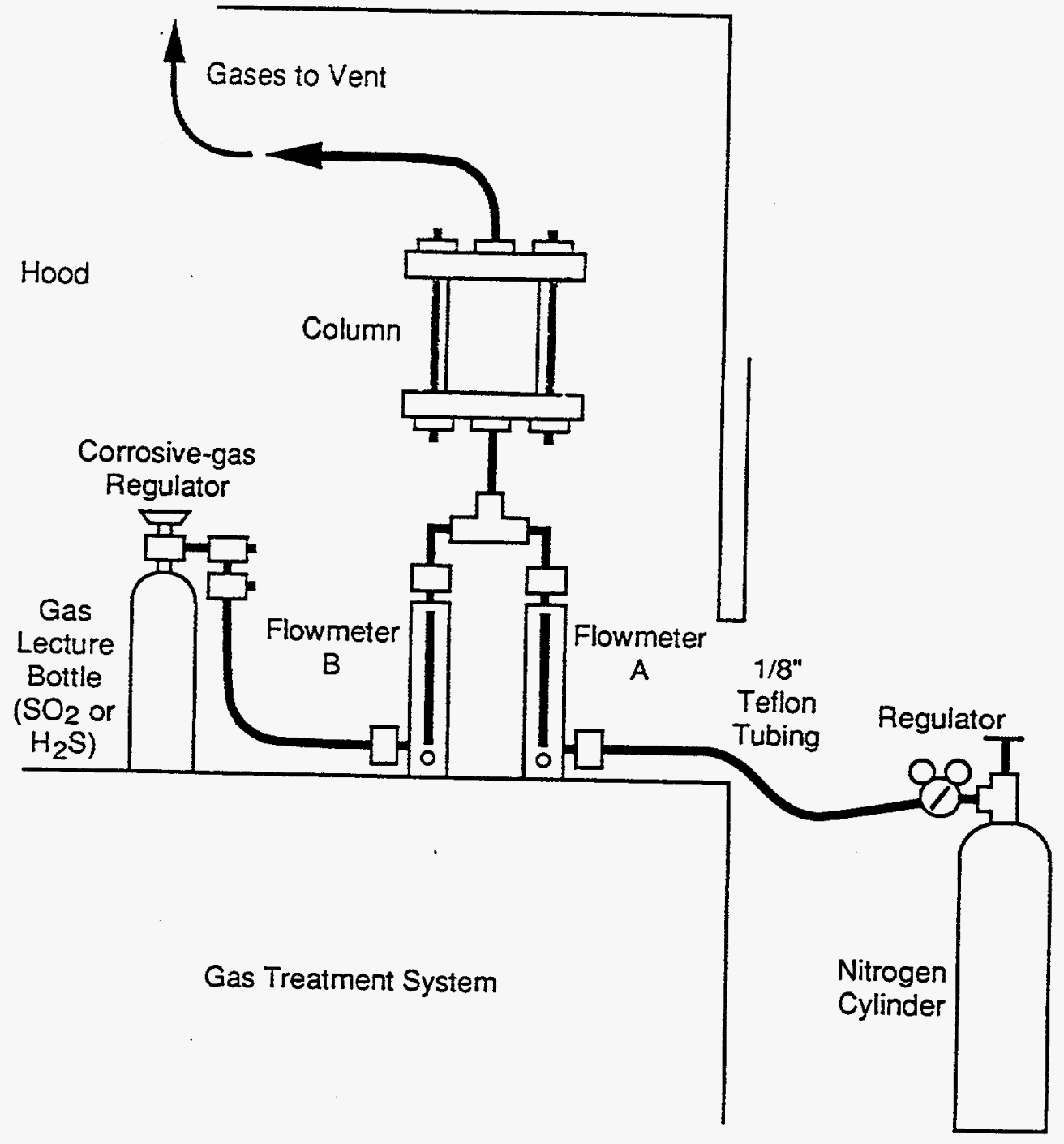

H9105015.3

Figure 2. Schematic Illustration of Gas Treatment System (not to scale). 


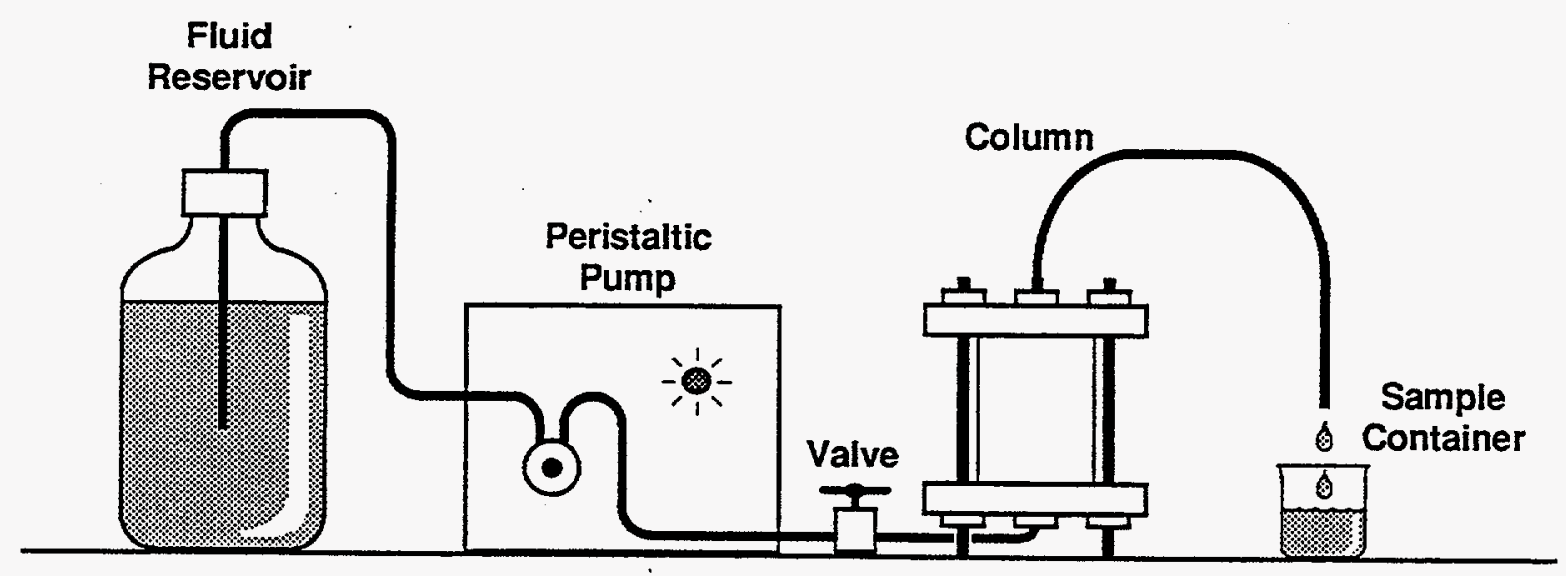

Column Leachate System

H9106007.1

Figure 3. Schematic Illustration of Column Leaching System (not to scale). 
Column leach tests were also conducted with several combinations of uncontaminated and untreated soil samples as test controls. These tests demonstrate that no detectable hexavalent chromium or uranium is present in the original soil samples but indicate that a minor amount of reduced chromium was leached from the soils as evidenced by total chromium concentrations of the leachate solutions (see Appendices A, B, and C). In addition, leach tests were conducted with contaminated soils that were untreated to determine the upper limit of recovery associated with each contaminant.

As indicated in Table 1, two tests (18 and 19) were also conducted with contaminated Hanford Site soil at low and high moisture contents $(0.88 \%$ and $9.70 \%$, respectively). The objective of these tests was to determine if treatment effectiveness is influenced by soil moisture content.

Blank samples consisting of the deionized water and groundwater used in the leach tests were also analyzed (Appendix A).

Analytical data for aqueous samples are presented in parts per million (ppm) units in this report and were reported by the analytical laboratory as milligrams of analyte per liter of sample. Thus, a ppm value associated with a specific aqueous analyte is a concentration unit based on weight per volume. Since the samples were relatively dilute, it is assumed that these concentration values may also be taken as milligrams of analyte per kilogram of solution without introducing significant error.

The tests identified in Table 1 are not sufficient in number to completely satisfy the requirements defined by a factorial design analysis of the full set of parameters being considered (three soil types, two hydrogen sulfide concentration levels, two contaminant constituents, three moisture content levels, nitrate at two concentration levels). At least 100 tests would be required to meet even the minimum requirements of such an approach. A testing program adequate to meet these requirements would be prohibitively expensive and probably require several years to complete. The objective of this study, rather, was to obtain some insight into the relative importance of these parameters by performing a few selected tests. For the Hanford soil, however, a $2 \times 2$ full-factorial test matrix was employed using nitrate and hydrogen sulfide concentrations as the test variables and chromium and uranium as the contaminant constituents (tests 4 through 7 of Table 1).

It should also be pointed out that no duplicate tests were performed during this study. A duplicate test was performed, however, in an earlier study (Thornton et al. 1991), and a high level of reproducibility was achieved. Moreover, the internal consistency of the results of this study and general agreement with the results obtained in the earlier study suggest that experimental reproducibility is adequate.

\subsection{ANALYTICAL METHODS AND QUALITY CONTROL REQUIREMENTS}

All analytical activities performed in this study involved the use of reagent-grade chemicals and standards prepared by WHC analytical laboratories or commercial suppliers. American Society for Testing and Materials (ASTM) Type II water was utilized in preparation of standard solutions and blanks. Analytical procedures and associated quality control requirements are discussed below. Standards were not matrix-matched to the samples during these analyses. This 
is not considered to be a significant source of error, however, since the samples were dilute and matrix effects therefore minor.

Hexavalent chromium concentrations in the leachate samples were measured with a spectrophotometer using the diphenylcarbazide colorimetric method per WHC Analytical Laboratory Procedure LA-265-401. Quality control protocol for this method consists of running verification standards with $a \pm 10 \%$ limitation of recovery $(90 \%-110 \%)$. A detection level of $0.05 \mathrm{ppm}$ was reported by the analyst.

Total chromium and other cations were determined by inductively coupled plasma (ICP) emission spectrometry per WHC Analytical Laboratory Procedure LA 505-151. This method incorporates the quality assurance requirements of U.S. Environmental Protection Agency (EPA) Method 6010, SW-846, Test Methods. To ensure calibration accuracy during each analysis run, the procedure requires that the deviation of the continuing calibration verification standards must not be greater than $\pm 10 \%$ of the true value to be acceptable.

Nitrate and other anions in the leachate samples were analyzed by ion chromatography (IC) per WHC Analytical Laboratory Procedure LA-533-105, which is equivalent to EPA Method 300.0. Examination of check standards run during the analyses indicate a $\pm 5 \%$ or better limitation of recovery.

Uranium concentrations of the leachate samples were determined by laser fluorometry per WHC Analytical Laboratory Procedure LA-925-106. The precision and accuracy of this method are estimated to be $\pm 20 \%$ at the $95 \%$ confidence level. A detection level of about $4 \mu \mathrm{g} / \mathrm{L}$ (4 ppb) was achieved.

Routine $\mathrm{pH}$ electrode determinations were also performed on the leachate samples. Calibration with buffer solutions was performed for each batch of samples measured, and $\mathrm{pH}$ values were judged to be accurate to \pm 0.05 units. 
WHC-EP-0694 


\subsection{RESULTS AND DISCUSSION}

\subsection{GAS TREATMENT AND SOIL COLUMN LEACH TESTS}

This section summarizes the results of a series of tests undertaken to evaluate the use of hydrogen sulfide for reducing and immobilizing chromium and uranium in three soils contaminated by these constituents. The testing approach consisted of preparing soils that contained $200 \mathrm{ppm} \mathrm{Cr}(\mathrm{VI})$ and/or $200 \mathrm{ppm}$ U(VI), packing the contaminated soil in a column, treating the soil by passing the treatment gas mixture through the column, and leaching the treated soil by passing deionized water or groundwater through the column (Section 3.2 and WHC 1993b). The degree of treatment was then determined by comparing the amounts of hexavalent and total chromium and uranium retrieved in the leachate samples with those of untreated control tests. A test matrix is presented in Table 1, and test data are provided in Appendices A, B, and C.

\subsubsection{Hanford Soil Tests}

A sample of the uncontaminated and untreated Hanford Site soil was leached in test 1 with groundwater. Analysis of the leachate samples indicated that no hexavalent chromium or uranium is present in the soil (Appendix A). Analysis of total chromium indicated, however, that a minor amount of chromium was present in three of the leachate samples, probably in the trivalent oxidation state. Based on these analyses, the total amount of leachable chromium in the soil is approximately $32 \mathrm{ppb}$ ( $32 \mu \mathrm{g}$ chromium per $\mathrm{kg}$ of soil; Appendix B).

The uncontaminated Hanford Site soil was treated with $2000 \mathrm{ppm} \mathrm{H}_{2} \mathrm{~S}$ in test 2 and leached with groundwater. Analysis of the leachate samples from this test indicated insignificant concentrations of $\mathrm{Cr}(\mathrm{VI})$ and total chromium, suggesting that perhaps the hydrogen sulfide tied up even the trace amount of chromium that was leachable in the untreated soil. Uranium was at or below detection limits for the leachate samples of test 2 . Note that a significant concentration of nitrate was observed in the first leachate samples of tests 1 and 2 . No nitrite was observed in test 2 , which involved treatment of the soil by hydrogen sulfide.

A portion of contaminated and untreated Hanford Site soil was leached with groundwater in test 3. The total amount of hexavalent chromium recovered in the leachate samples was $59.9 \%$ (see Appendix B). Thus, approximately $40 \%$ of the hexavalent chromium was retained in the column and/or reduced by interaction with the soil (Table 2). Similar values for concentrations of $\mathrm{Cr}(\mathrm{VI})$ and total chromium in the leachate samples indicate that essentially all of the chromium that was mobile was in the hexavalent oxidation state.

A total of about $69.5 \%$ of the uranium added to the soil in test 3 was recovered during leaching (Appendix C), indicating an immobilization factor of $30.5 \%$. The nitrate concentration values of the leachate samples for test 3 indicate essentially $100 \%$ recovery in the first leachate sample. Nitrite was below the limits of detection in all leachate samples. The leachate sample data also indicates that all leachable chloride and sulfate were recovered in the first leachate sample, with concentration values for these constituents dropping to groundwater levels in the subsequent samples (see groundwater analysis of Appendix A). 
Table 2. Summary of $\mathrm{H}_{2} \mathrm{~S}$ Treatment Parameters and Results of Hanford Site Soil Treatment Tests.

\begin{tabular}{|c|c|c|c|c|}
\hline Test \# & $\begin{array}{c}\text { ppm } \mathrm{H}_{2} \mathrm{~S} \\
\text { in gas } \\
\text { mixture }\end{array}$ & $\begin{array}{c}\text { Treatment } \\
\text { duration }\end{array}$ & $\begin{array}{c}\% \mathrm{Cr}(\mathrm{VI}) \\
\text { immobilized }\end{array}$ & $\begin{array}{c}\% \mathrm{U} \\
\text { immobilized }\end{array}$ \\
\hline 3 & none & - & 40.1 & 30.5 \\
\hline 4 & 2,000 & $73.7 \mathrm{~min}$ & 94.6 & 55.3 \\
\hline 5 & 100 & $25.5 \mathrm{hr}$ & 98.4 & 67.1 \\
\hline 6 & 2,000 & $73.7 \mathrm{~min}$ & 96.0 & 55.5 \\
\hline 7 & 100 & $25.5 \mathrm{hr}$ & 94.3 & 54.7 \\
\hline 18 & 2,000 & $73.8 \mathrm{~min}$ & 88.7 & 55.7 \\
\hline 19 & 2,000 & $73.7 \mathrm{~min}$ & 98.6 & 59.5 \\
\hline
\end{tabular}

The $\mathrm{pH}$ of leachate samples obtained in test 3 ranged from 8.27 to 8.97 . This is consistent with the principles of carbonate equilibria, which predict a pH of 8.4 for the system calcite-water and atmospheric carbon dioxide (Garrels and Christ 1965). An analysis of the Hanford Site soil sample employed in these tests indicated the presence of $2.1 \mathrm{wt} \%$ calcium carbonate.

Gas treatment of the contaminated Hanford Site soil was undertaken in tests 4 and 5 with hydrogen sulfide at concentrations of $2000 \mathrm{ppm}$ and $100 \mathrm{ppm}$, respectively, and the treated soils were subsequently leached with groundwater. The treatment parameters and chromium immobilization results for these tests are summarized in Table 2 . The data for tests 3,4 , and 5 indicate recoveries of $59.9 \%, 5.4 \%$, and $1.6 \%$ of $\mathrm{Cr}(\mathrm{VI})$ (immobilization of $40.1 \%, 94.6 \%$, and $98.4 \%$, respectively, of hexavalent chromium added to soil). Figure 4 illustrates the variation of $\mathrm{Cr}(\mathrm{VI})$ leachability during these three tests. These results indicate that treatment of chromate contaminated soils with concentrations of hydrogen sulfide as low as $100 \mathrm{ppm}$ is a potentially effective remediation approach. Figure 4 also illustrates that chromium was irreversibly immobilized in tests 4 and 5 during the leach phase of the tests, which was approximately a week in duration.

Uranium recoveries were $69.5 \%, 44.7 \%$, and $32.9 \%$ for tests 3,4 , and 5 (immobilization factors of $31.5 \%, 55.3 \%$, and $67.1 \%$, respectively; Appendix $C$ and Table 2). Thus, a significant degree of immobilization is achieved by gas treatment. Figure 5 illustrates that uranium is not irreversibly immobilized by treatment, however, as indicated by the presence of uranium in the leachate samples throughout the duration of the leaching phase of tests 4 and 5 . These results suggest that reoxidation of U(IV) back to $U(V I)$ occurs during leaching, possibly due to oxygen dissolved in the leachate solution. Eh-pH diagrams presented in Langmuir (1978) indicate that uraninite, $\mathrm{UO}_{2(c)}$, can be oxidized and dissolved as uranyl carbonate complexes at an Eh value (oxidation potential) of about 0.1 volts in a neutral solution in equilibrium with atmospheric $\mathrm{CO}_{2}$. This contrasts with an Eh of about 0.5 volts required to oxidize trivalent chromium oxide to the soluble hexavalent chromate complexes (see Figure 1). 


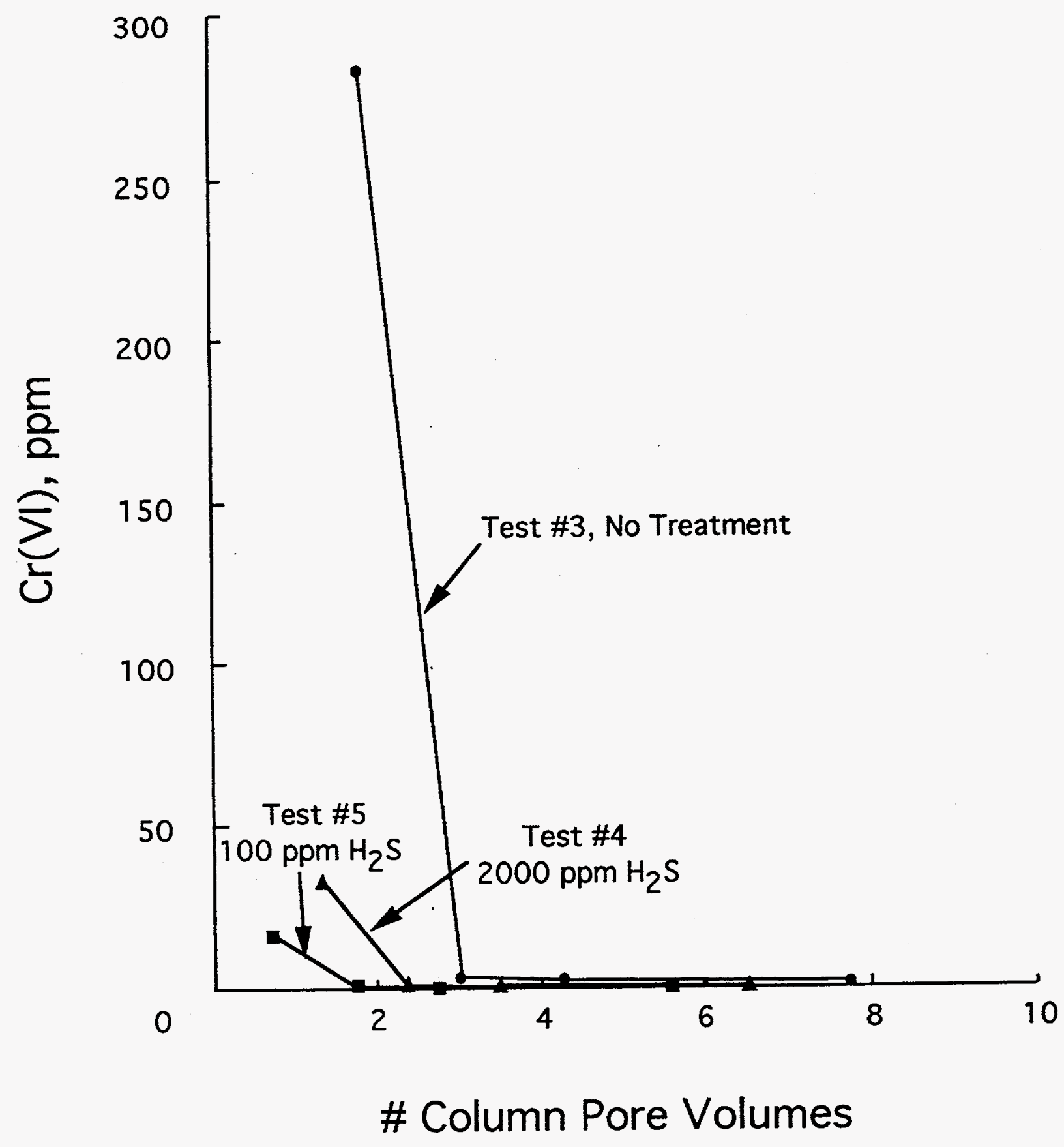

Figure 4. Cr(VI) Concentrations of Leachate Samples for Hanford Site Soil Treatment Tests 3, 4, and 5 . 


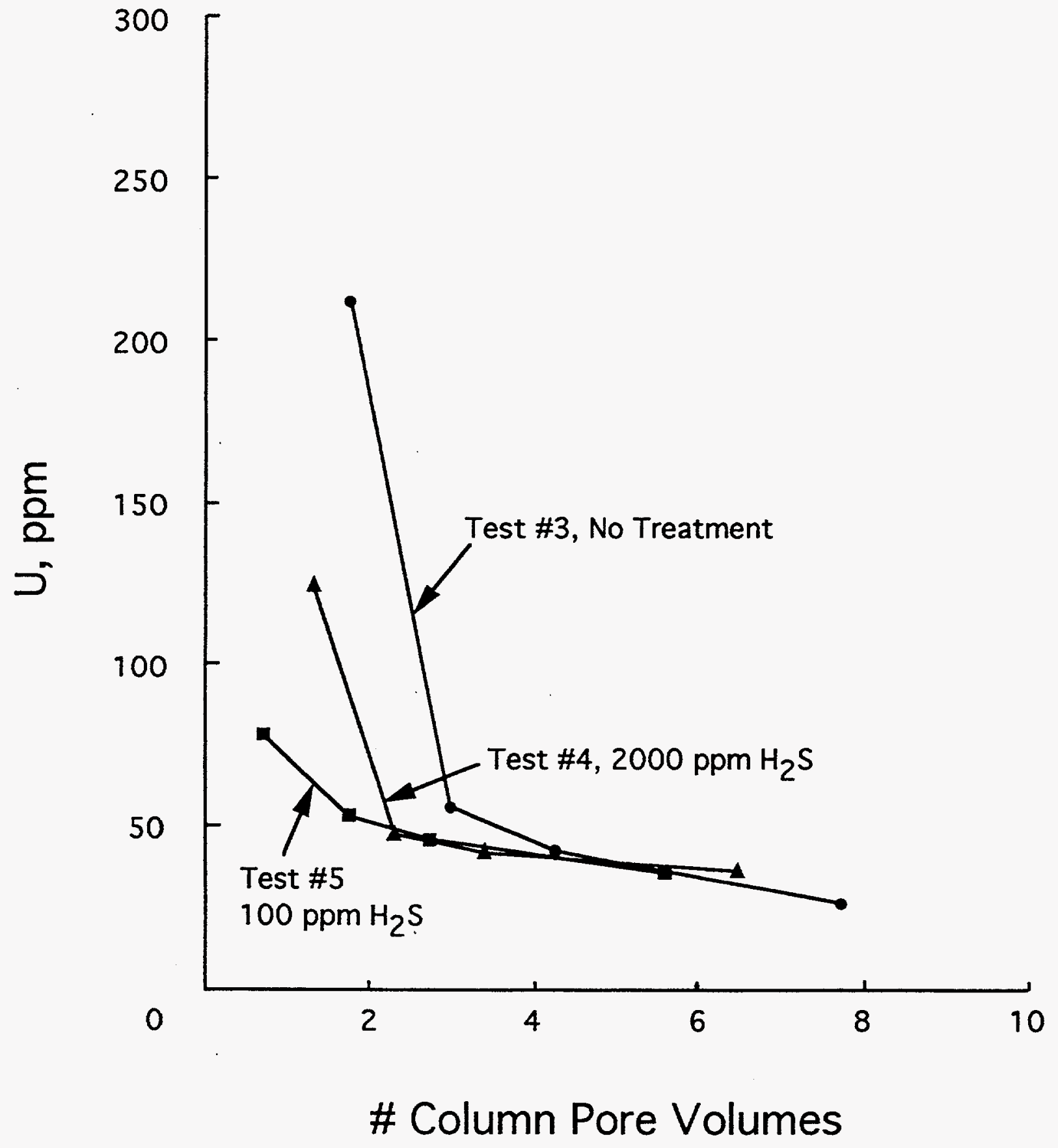

Figure 5. Uranium Concentrations of Leachate Samples for Hanford Site Soil Treatment Tests 3, 4 , and 5. 
Essentially $100 \%$ recovery of nitrate was observed for the three tests, indicating that hydrogen sulfide had no discernable effect on this contaminant constituent. Nitrite concentration levels were at or below the limits of detection for all leachates obtained from tests 3,4 , and 5 .

The Hanford Site soil was contaminated with a higher concentration of nitrate $(5000 \mathrm{ppm})$ in tests 6 and 7, in addition to $200 \mathrm{ppm}$ of hexavalent chromium and uranium. The objective of supplying additional nitrate was to determine if nitrate significantly interferes with immobilization of chromium and uranium and to determine if nitrite, a potentially hazardous byproduct, can be generated by reduction of nitrate. This is relevant in that nitrate contamination is frequently associated with chromate and uranium in soil waste sites.

The nitrate-contaminated soil was treated with $2000 \mathrm{ppm}$ hydrogen sulfide in test 6 and $100 \mathrm{ppm}$ in test 7. Recovery of $\mathrm{Cr}(\mathrm{VI})$ was $4.0 \%$ for test 6 and $5.7 \%$ for test 7 (immobilization of $96.0 \%$ and $94.3 \%$, respectively). A comparison of the $\mathrm{Cr}(\mathrm{VI})$ concentration of leachate samples versus number of column pore volumes for tests 3,6 , and 7 is illustrated by Figure 6 . It is concluded that the presence of extra nitrate did not significantly affect the treatment results since $\mathrm{Cr}(\mathrm{VI})$ recovery factors for tests $4,5,6$, and 7 are similar. Essentially all the added nitrate was recovered in the leachate samples for tests 6 and 7 and no nitrite was detected, further indicating that no significant interaction of hydrogen sulfide with nitrate occurred during treatment. Figure 6 also illustrates that chromium was again irreversibly immobilized in tests 6 and 7 .

Uranium recoveries of $44.5 \%$ and $45.3 \%$ were obtained for tests 6 and 7 (immobilization factors of $55.5 \%$ and $54.7 \%$, respectively). Note that these results are similar to those of tests 4 and 5 and thus also indicate that the presence of nitrate does not appear to significantly influence the degree to which uranium is immobilized. Figure 7 indicates that uranium was not irreversibly immobilized by hydrogen sulfide treatment in tests 6 and 7 .

The Hanford Site soil was also contaminated with chromium, uranium, and nitrate in tests 18 and 19 , but moisture contents were adjusted to $0.88 \%$ and $9.70 \%$, respectively. A 2000 ppm hydrogen sulfide gas mixture was used to treat the soil in both tests. The results of these two tests in conjunction with test 4 (moisture content $=5.11 \%$ ) can be used as to assess the effect of moisture content on the reduction and immobilization process. A comparison of the results presented in Table 2 and in Figure 8 suggests that immobilization of hexavalent chromium is dependent to some degree on soil moisture content and appears to be enhanced as moisture content increases (i.e., hexavalent chromium immobilization was $88.7 \%, 94.6 \%$, and $98.6 \%$ for soil moisture contents of $0.88 \%, 5.11 \%$, and $9.70 \%$, respectively). This may indicate that reaction in pore fluids is more effective than is direct reaction between the treatment gas and solid chromate salts.

Uranium recoveries were $44.3 \%$ and $40.5 \%$ for tests 18 and 19 (immobilization factors of $55.7 \%$ and $59.5 \%$, respectively) and thus similar to that of the other tests involving uranium described above. A comparison of tests 4, 18, and 19 does not clearly indicate that immobilization of uranium by the gas treatment process is strongly dependent on soil moisture content, although the highest immobilization factor was associated with the test having the highest moisture content. Figure 9 illustrates that after passage of several column pore volumes, similar concentration. levels of uranium in the leachate fluids were observed. Essentially all of the nitrate added to the soils in tests 18 and 19 was recovered in the leachate samples and no nitrite was detected. 


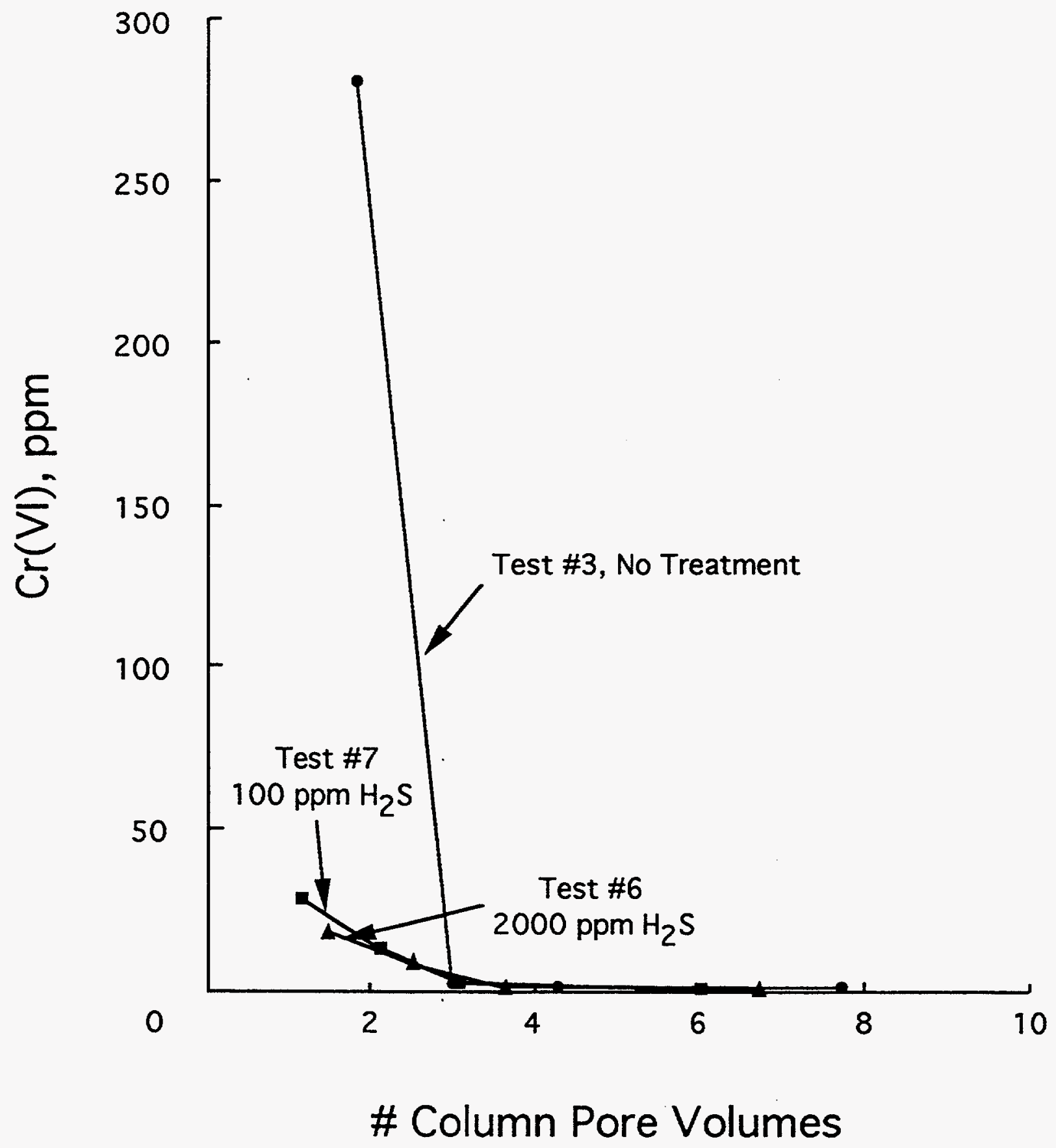

Figure 6. $\mathrm{Cr}(\mathrm{VI})$ Concentrations of Leachate Samples for Hanford Site Soil Treatment Tests 3, 6, and 7. 


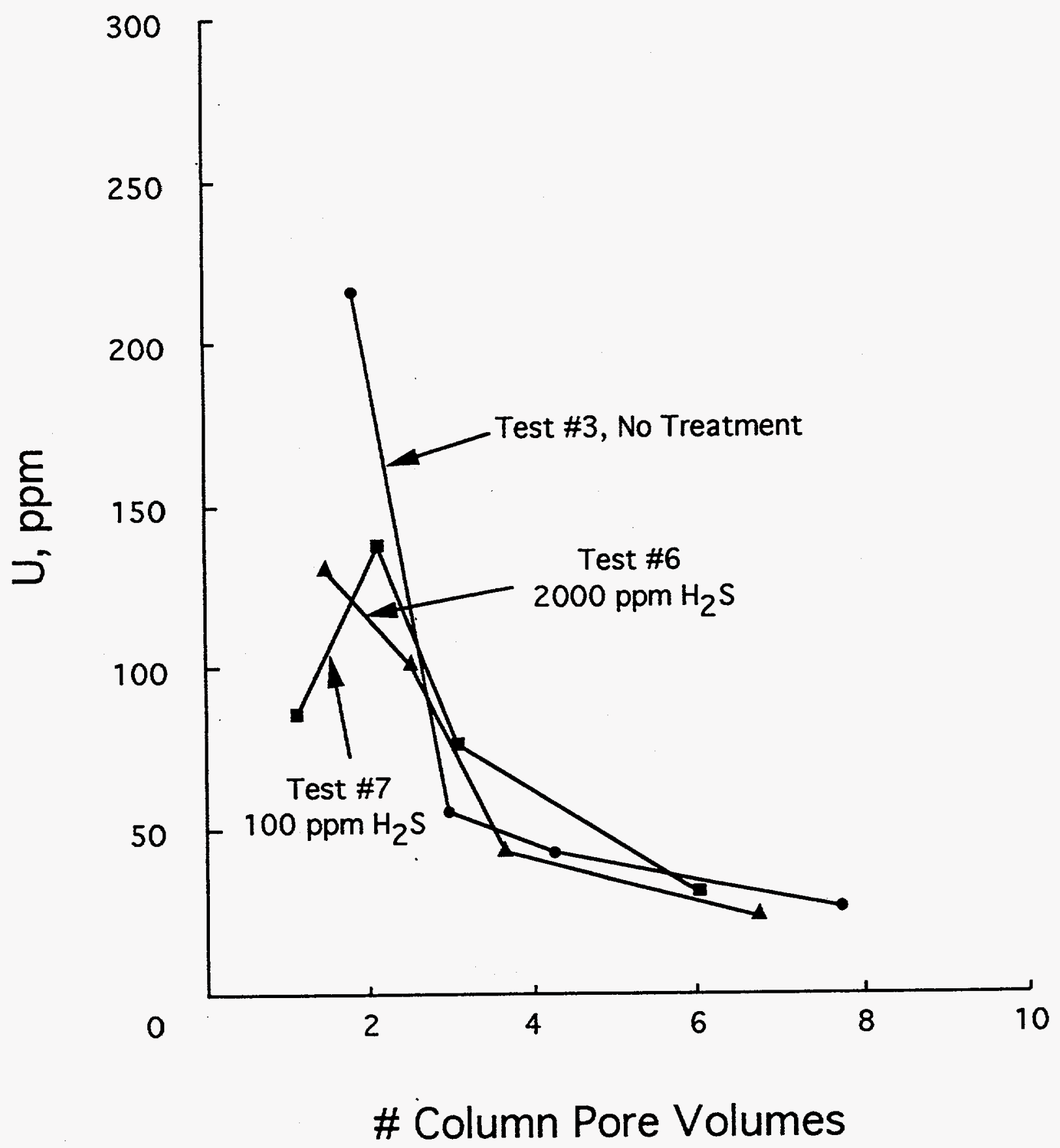

Figure 7. Uranium Concentrations of Leachate Samples for Hanford Site Soil Treatment Tests 3, 6 , and 7. 


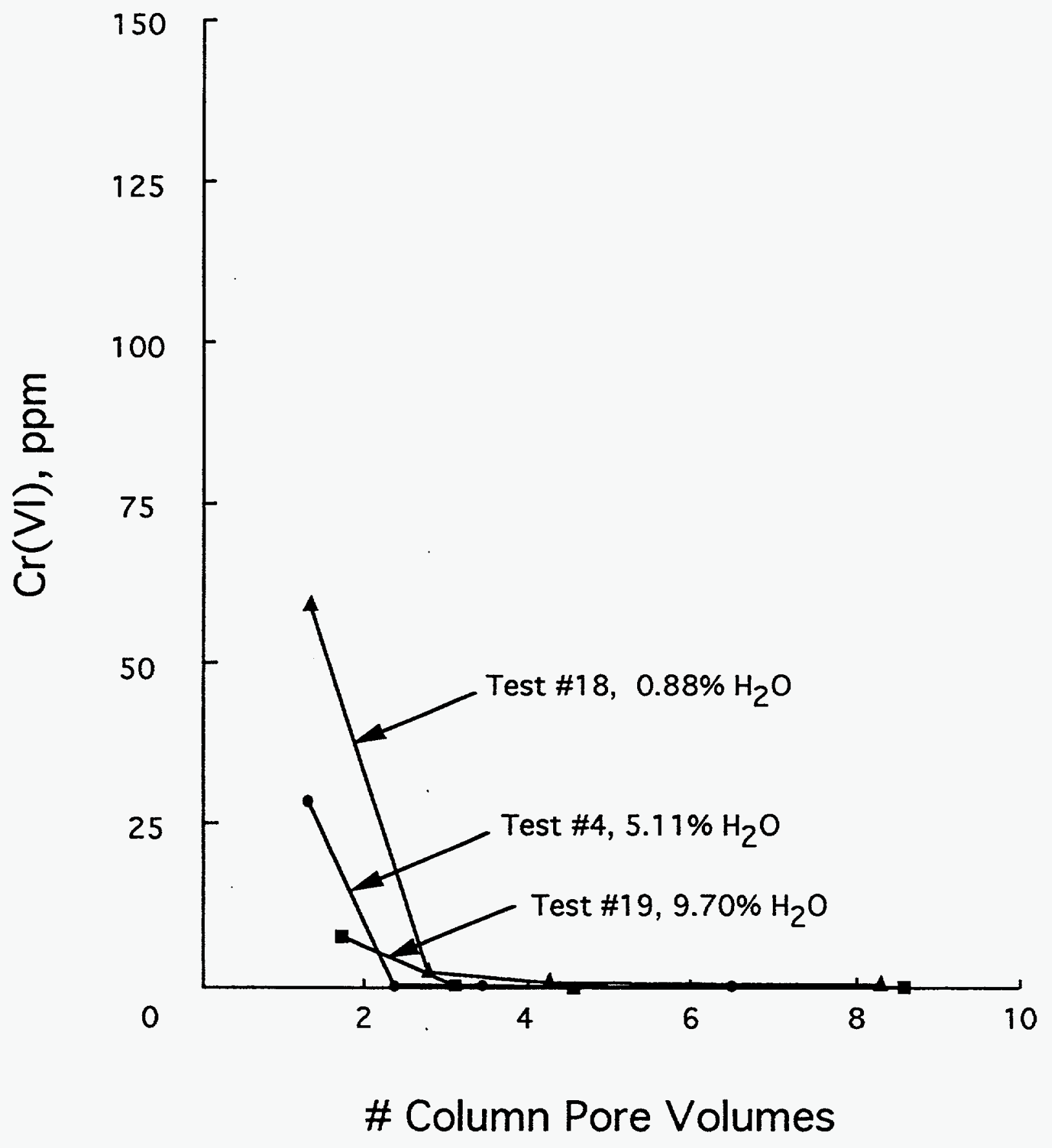

Figure 8. $\mathrm{Cr}(\mathrm{VI})$ Concentrations of Leachate Samples for Hanford Site Soil Treatment Tests 4, 18, and 19. 


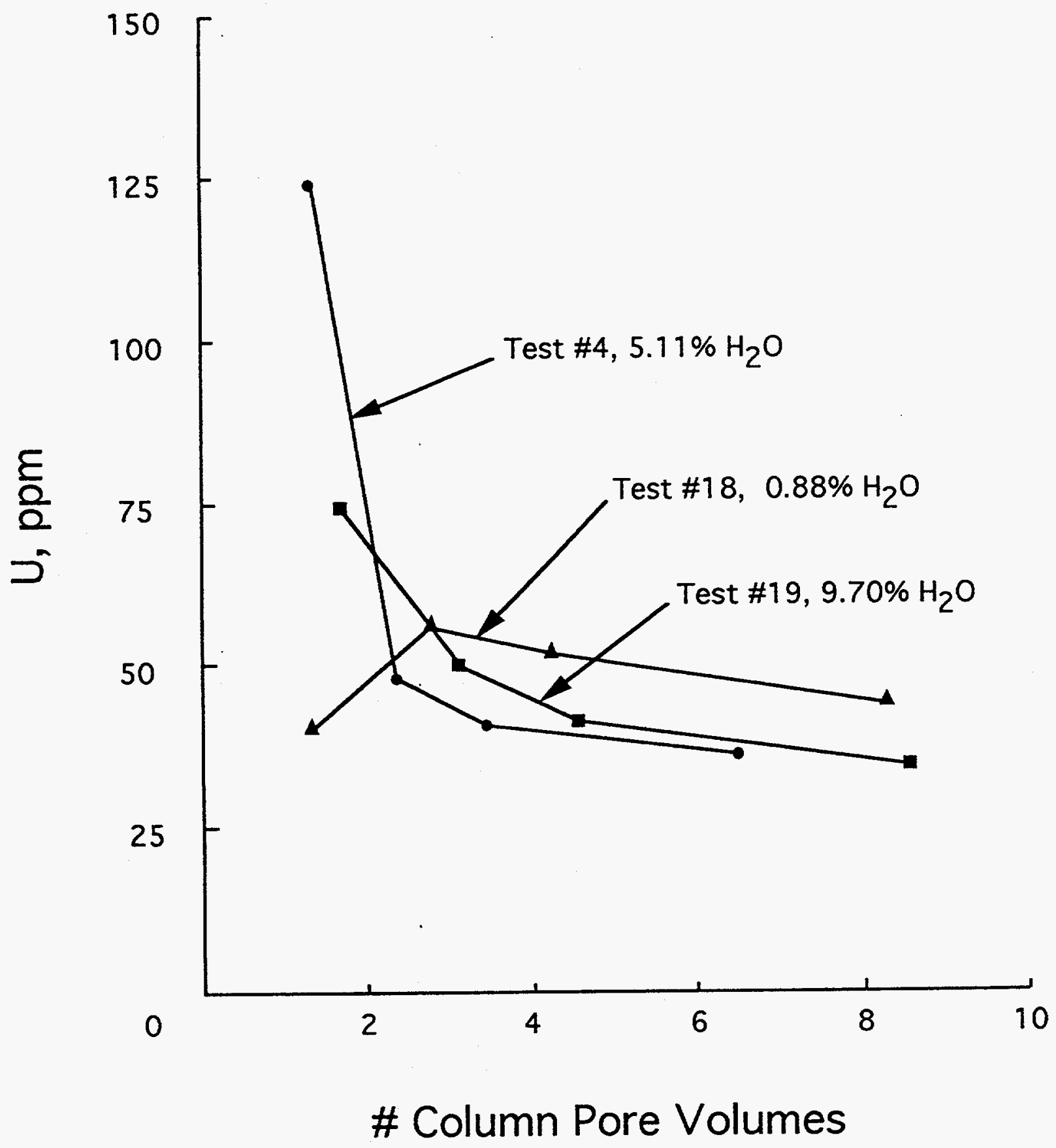

Figure 9. Uranium Concentrations of Leachate Samples for Hanford Site Column Leach Tests 4, 18 , and 19. 
Analyses of the first leachate samples of tests 18 and 19 (leachate samples 3-0761-1 and 3-0762-1) for cations and anions were performed by ICP and are reported in Appendix A. Low content of metals (other than chromium) in these samples indicate that the treatment process does not result in the release of metals to pore solutions.

Total chromium and $\mathrm{pH}$ measurements were performed on most of the leachate samples collected in this set of tests (Appendix A). The total chromium concentrations of the samples were essentially equal to the $\mathrm{Cr}(\mathrm{VI})$ concentrations, indicating that chromium was both reduced and immobilized effectively during gas treatment. Examination of chromium values of the leachates associated with the Hanford soil tests also suggests that immobilization of chromium by gas treatment is an irreversible process. The average $\mathrm{pH}$ was about 8.5 in this set of tests for both treated and untreated samples, suggesting that the treatment process does not significantly affect this parameter. This $\mathrm{pH}$ value reflects that of the groundwater and is also consistent with carbonate equilibria processes in the system calcite-water and atmospheric carbon dioxide (Garrels and Christ 1965).

\subsubsection{Sandia Soil Tests}

A portion of uncontaminated and untreated Sandia soil was leached in test 8 with deionized water. Analytical results for the leachate samples from this test indicate that no hexavalent chromium or uranium is present in the soil (see Appendix A). All total chromium values were also below the limits of detection. A minor amount of nitrate was observed in the first leachate sample, indicating that only a small amount of nitrate is present in the uncontaminated soil.

An uncontaminated portion of the Sandia soil was treated with $2000 \mathrm{ppm} \mathrm{H}_{2} \mathrm{~S}$ in test 9 and leached with deionized water. No chromium or uranium was detected in the leachate samples associated with this test, and nitrate was present at a low concentration level in the first sample only. No nitrite was detected in either test 8 or test 9 . A minor amount of sulfate was detected in the leachate samples of both tests. The sulfate content of the leachate samples from test 9 was slightly higher, however, suggesting that a portion of the hydrogen sulfide used during treatment was oxidized by the soil to produce sulfate.

A portion of the Sandia soil was contaminated to $200 \mathrm{ppm}$ with $\mathrm{Cr}(\mathrm{VI})$ in test 10 and leached with deionized water. The total amount of hexavalent chromium recovered in the leachate samples was $60.8 \%$ (39.2\% immobilization; Table 3). Similar values for concentrations of $\mathrm{Cr}(\mathrm{VI})$ and total chromium were obtained. A concentration of $18.4 \mathrm{ppm}$ of uranium was reported for the first leachate sample, and a moderate amount of nitrate was also observed (see Appendix A). The presence of uranium and nitrate suggests that the $\mathrm{Cr}(\mathrm{VI})$ stock solution used to spike the soil was contaminated with a minor amount of uranium nitrate. The level of cross contamination, however, is judged not to be high enough to affect significantly the conclusions regarding uranium immobilization efficiencies reported for the tests involving the Hanford and Fernald soil tests.

Gas treatment of the $\mathrm{Cr}(\mathrm{VI})$-contaminated Sandia soil was undertaken in tests 11 and 12 with hydrogen sulfide at concentrations of $2000 \mathrm{ppm}$ and $100 \mathrm{ppm}$, respectively, and the treated soil samples were subsequently leached with deionized water. The data for tests 10,11 , and 12 indicate recoveries for $\mathrm{Cr}(\mathrm{VI})$ of $60.8 \%, 6.5 \%$, and $4.8 \%$ (immobilization of $39.2 \%, 93.5 \%$, and $95.2 \%$, respectively; see Table 3 ). A comparison of $\mathrm{Cr}(\mathrm{VI})$ leachability for these tests is presented in Figure 10. 
Table 3. Summary of $\mathrm{H}_{2} \mathrm{~S}$ Treatment Parameters and Results of Sandia Soil Treatment Tests.

\begin{tabular}{|c|c|c|c|}
\hline $\begin{array}{c}\text { Test } \\
\text { Number }\end{array}$ & $\begin{array}{c}\text { ppm } \mathrm{H}_{2} \mathrm{~S} \\
\text { in gas } \\
\text { mixture }\end{array}$ & $\begin{array}{c}\text { Treatment } \\
\text { duration }\end{array}$ & $\begin{array}{c}\% \mathrm{Cr}(\mathrm{VI}) \\
\text { immobilized }\end{array}$ \\
\hline 10 & none & - & 39.2 \\
\hline 11 & 2,000 & $60.2 \mathrm{~min}$ & 93.5 \\
\hline 12 & 100 & $20.9 \mathrm{hr}$ & 95.2 \\
\hline
\end{tabular}

Analyses of the first leachate samples of tests 10 and 12 (leachate samples 3-0753-1 and 3-0755-1) for cations and anions were performed by ICP and are reported in Appendix A. The leachate of test 12 has a lower chromium content than test 10 since the soil of test 12 was treated with hydrogen sulfide. It is interesting to note that the leachate of test 12 also contained $0.86 \mathrm{ppm}$ manganese, which can be attributed to the reduction of manganese oxide phases in the soil by hydrogen sulfide. Manganese is identified as a contaminant constituent under the secondary drinking water standards (Title 40, Code of Federal Regulations, Part 143), but is unlikely to be considered detrimental at the trace levels observed. Analytical results for the two leachate samples indicate that the treatment process does not result in the release of any other metals to pore solutions.

Total chromium and $\mathrm{pH}$ measurements were performed on most of the leachate samples collected in association with tests conducted on the Sandia soil. The total chromium concentrations of the leachate samples were essentially equal to the $\mathrm{Cr}(\mathrm{VI})$ concentrations (see tests 10 and 12), indicating that gas treatment resulted in both reduction and immobilization of hexavalent chromium. The $\mathrm{pH}$ values of the leachate solutions of all tests involving the Sandia soil ranged from 8.0 to 8.6 , probably reflecting the significant carbonate content of this soil (30 wt \% as $\mathrm{CaCO}_{3}$ ).

\subsubsection{Fernald Soil Tests}

A untreated sample of the uncontaminated soil from Fernald was leached in test 13 with deionized water. Analysis of the leachate samples indicates that no hexavalent chromium is present in the soil, but trace levels of uranium exist (see Appendix A). Trace levels of total chromium were also reported for the first two leachate samples of the test. Mass balance calculations indicate that the soil contains approximately $27 \mathrm{ppb}$ leachable total chromium (see Appendix B) and $22 \mathrm{ppb}$ leachable uranium. A rather substantial amount of nitrate was also observed in the first leachate sample (423 ppm), but nitrate was absent in subsequent samples. 


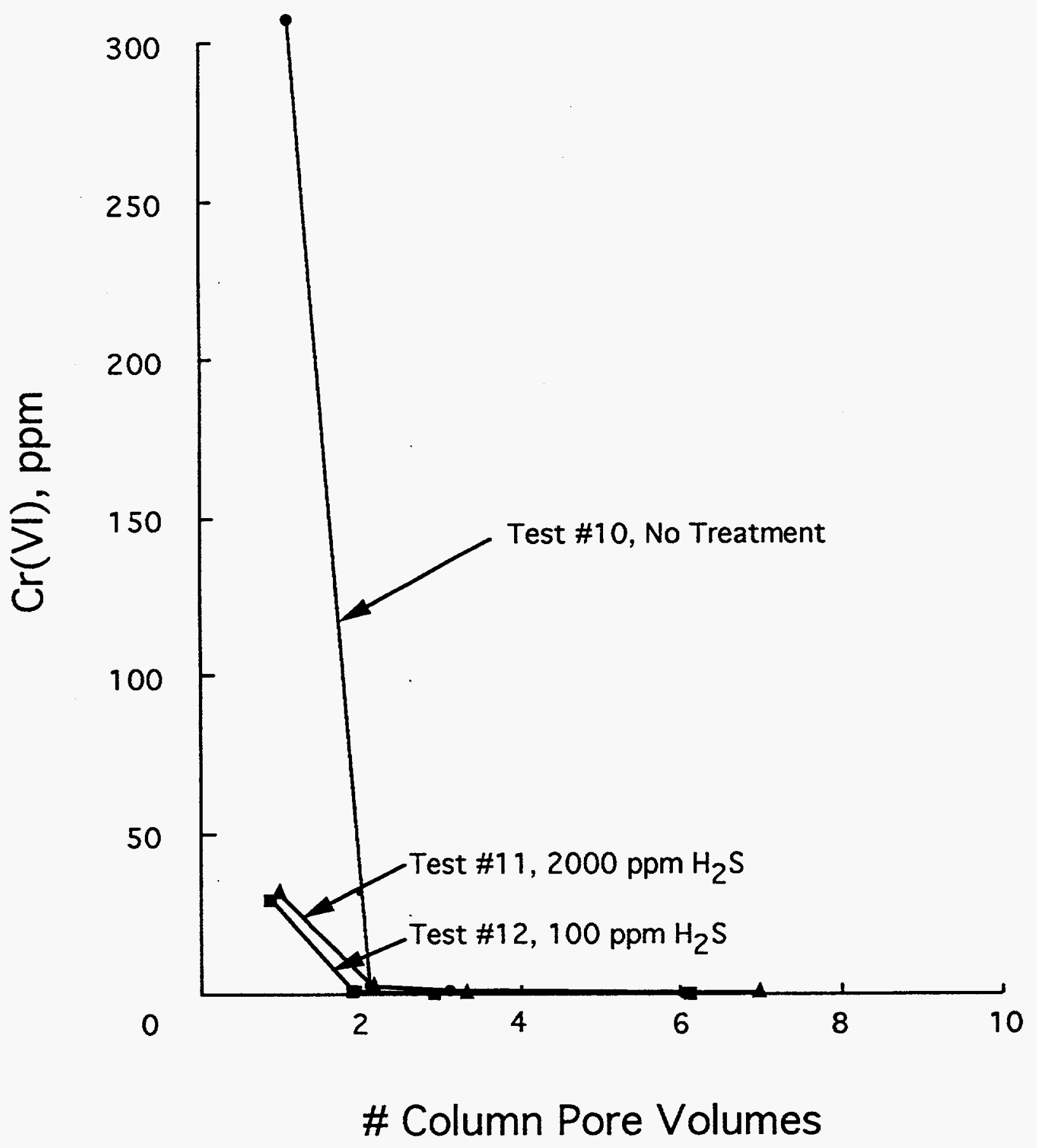

Figure 10. $\mathrm{Cr}(\mathrm{VI})$ Concentrations of Leachate Samples for Sandia Soil Treatment Tests 10, 11, and 12. 
An uncontaminated portion of the Fernald soil was treated with $2000 \mathrm{ppm}_{2} \mathrm{~S}$ in test 14 and leached with deionized water. Trace levels of uranium and chromium were present in the leachate samples, and nitrate was below the limits of detection in all samples, including the first. Nitrite was not detected in either test 13 or 14 . Test 14 leachate samples contained somewhat more sulfate than those of test 13 .

A portion of the Fernald soil was contaminated to $200 \mathrm{ppm}$ with $\mathrm{Cr}(\mathrm{VI})$ and $\mathrm{U}(\mathrm{VI})$ and to $100 \mathrm{ppm}$ with nitrate. The contaminated soil was then leached with deionized water in test 15. The total amount of hexavalent chromium recovered in the leachate samples was only $25.9 \%$ (74.1\% immobilization; Table 4). Comparison of hexavalent chromium and total chromium concentration values for the leachate samples indicates that essentially all the chromium present in the solutions was in the hexavalent oxidation state. The low recovery of chromium is attributed to the high organic content of the soil, which served to reduce and precipitate or adsorb the hexavalent chromium added to the soil. Only $1.6 \%$ of the total amount of uranium added to the soil sample was recovered during the test $(98.4 \%$ immobilization), suggesting that this constituent was also immobilized by the high content of organic matter present in the soil. Essentially $100 \%$ of the nitrate added to the soil was recovered in the first leachate sample of test 15.

Table 4. Summary of $\mathrm{H}_{2} \mathrm{~S}$ Treatment Parameters and Results of Fernald Soil Treatment Tests.

\begin{tabular}{|c|c|c|c|c|}
\hline Test \# & $\begin{array}{c}\text { ppm } \mathrm{H}_{2} \mathrm{~S} \\
\text { in gas } \\
\text { mixture }\end{array}$ & $\begin{array}{c}\text { Treatment } \\
\text { duration }\end{array}$ & $\begin{array}{c}\% \mathrm{Cr}(\mathrm{VI}) \\
\text { immobilized }\end{array}$ & $\begin{array}{c}\% \text { Uranium } \\
\text { immobilized }\end{array}$ \\
\hline 15 & none & - & 74.1 & 98.4 \\
\hline 16 & 2,000 & $74.0 \mathrm{~min}$ & 100 & 95.1 \\
\hline 17 & 100 & $25.5 \mathrm{hr}$ & 100 & 98.5 \\
\hline
\end{tabular}

Note: $\%$ immobilized $=100 \%-\%$ recovered

Gas treatment of the contaminated Fernald soil was undertaken in tests 16 and 17 using hydrogen sulfide at concentrations of $2000 \mathrm{ppm}$ and $100 \mathrm{ppm}$, respectively, and the treated soil samples were subsequently leached with deionized water. The data for tests 16 and 17 indicate recoveries for $\mathrm{Cr}(\mathrm{VI})$ of $<0.05 \%$ and $0.25 \%$ (immobilization of $100 \%$ and $99.75 \%$, respectively; Table 4), indicating essentially complete immobilization of hexavalent chromium by gas treatment (Figure 11). Uranium recoveries for tests 15,16 , and 17 were not significantly different, all exhibiting recovery factors of less than $5 \%$ (see Table 4). Figure 12 illustrates that uranium is relatively immobile in the Fernald soil, probably owing to the presence of a significant amount of organic matter (9.7 wt\% organic carbon). The results of tests 15,16 , and 17 suggest that treatment with hydrogen sulfide has little added benefit for organic-rich soils, since organic matter is generally a potent reducing agent.

Nitrate recoveries for tests 16 and 17 were somewhat lower than those associated with the untreated contaminated soil of test 15. In addition, significant levels of nitrite were reported for 


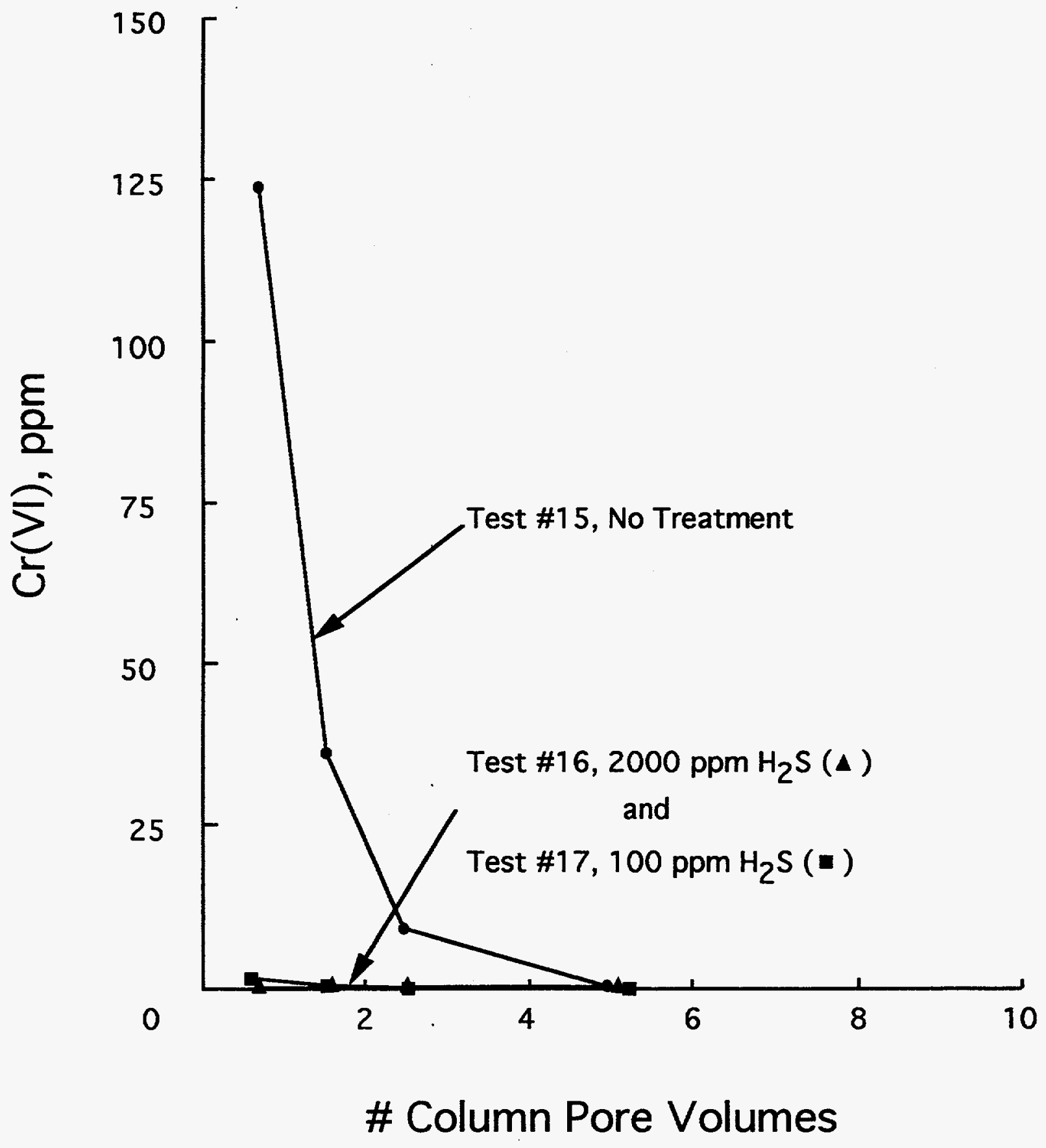

Figure 11. Cr(VI) Concentrations of Leachate Samples for Fernald Soil Treatment Tests 15, 16, and 17. 


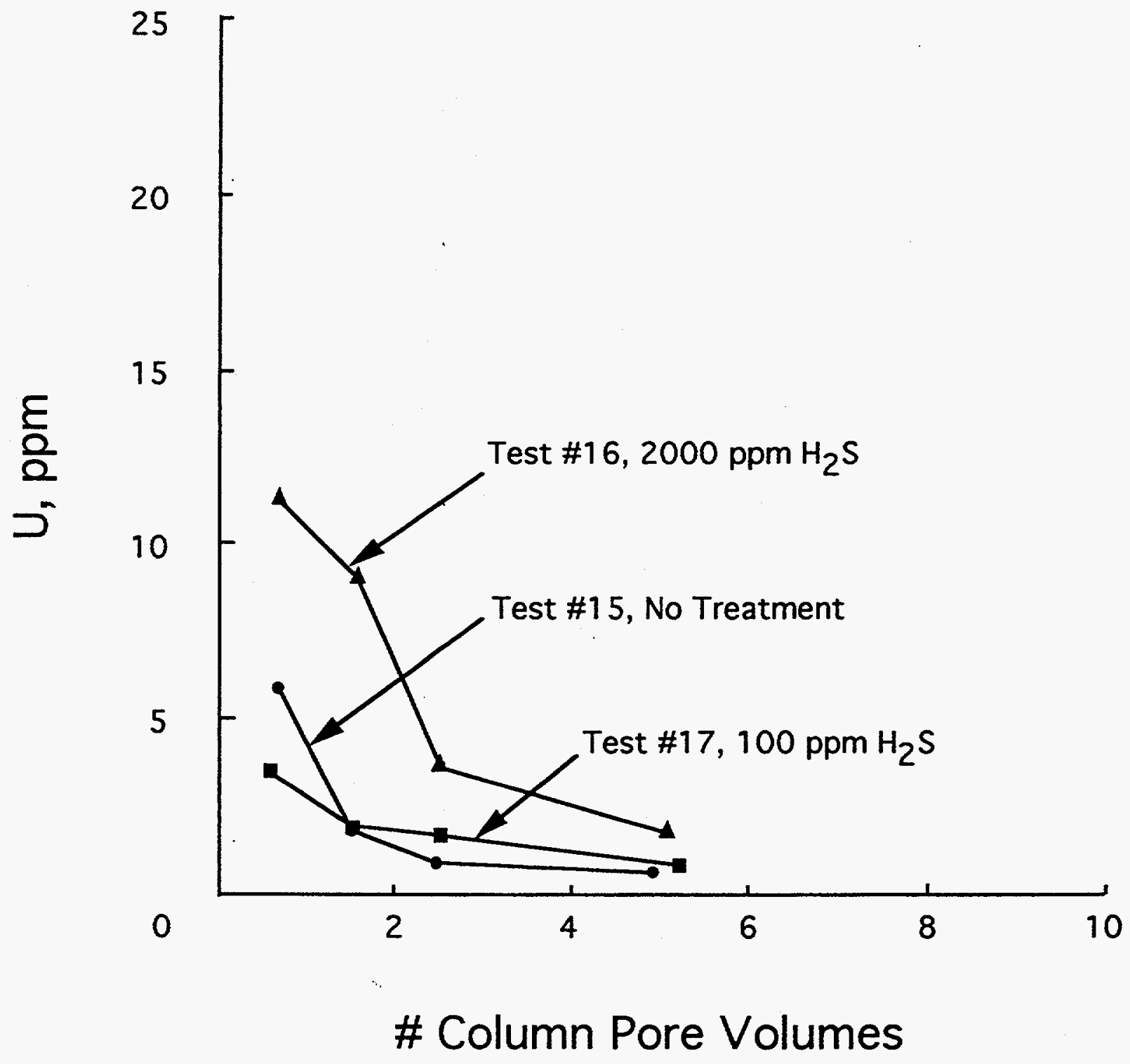

Figure 12. Uranium Concentrations of Leachate Samples for Fernald Soil Treatment Tests 15, 16, and 17. 
the first leachate samples of tests 16 and 17 . Thus, it appears that reduction of nitrate to nitrite may occur in organic, clay-rich soils if treated with hydrogen sulfide. The Fernald soil samples that were treated with hydrogen sulfide also exhibited moderately higher levels of sulfate in the leachate samples compared to the leachate samples of untreated soil. The latter effect is notconsidered detrimental, however, since sulfate is generally not a constituent of significant environmental concern.

Analyse of the first leachate samples of tests $13,15,16$, and 17 (leachate samples 3-0756-1, 3-0758, 3-0759-1, and 3-0760-1) for cations and anions were performed by ICP and are reported in Appendix $A$. The variations in total chromium content are related to the testing activities discussed previously. A release of manganese was again identified in the leachates of two tests that received hydrogen sulfide treatment (tests 16 and 17). A minor amount of aluminum was also detected in the first leachate sample of test 17 , but this could be due to the incorporation of a small amount of sediment in the leachate sample. Low content of other metals in the leachate samples indicate that the treatment process does not result in a significant release of hazardous metals to pore solutions. Elevated levels of sodium observed in tests 15, 16, and 17 may be attributed to use of sodium nitrate stock as the source for the nitrate spike added during the soil contamination procedure. The solution data associated with these tests is also somewhat elevated in calcium and magnesium, perhaps due to the displacement of calcium and magnesium present in exchangeable sites within the soil by the added sodium.

Total chromium and $\mathrm{pH}$ measurements were performed on all of the leachate samples collected in association with tests conducted on the Fernald soil. The total chromium concentrations of the leachate samples were slightly higher than the $\mathrm{Cr}(\mathrm{VI})$ concentrations, suggesting that a minor amount of $\mathrm{Cr}$ (III) was mobile. The $\mathrm{pH}$ values for the leachates associated with the Fernald soil tests ranged from about 7 to slightly greater than 8 . The slightly lower $\mathrm{pH}$ values of these tests compared to that of the Hanford and Sandia tests may be attributed to the higher organic and lower inorganic carbon content of the Fernald soil.

\subsection{SUMMARY OF TESTING RESULTS AND COMPARISON WITH REGULATORY GUIDELINES}

A performance goal of $50 \%$ immobilization of chromium and uranium was identified for this study since the soil samples employed were contaminated to levels of $200 \mathrm{ppm}$, and a cleanup goal of about $100 \mathrm{ppm}$ has been identified in several guidance documents (e.g., Method A Cleanup Levels - Soil, Table 2 of WAC 173-340; Table K-1 of WHC 1988). Results obtained from the tests conducted with the chromate-contaminated Hanford, Sandia, and Fernald soils indicate $>93 \%$ immobilization of chromium following treatment with hydrogen sulfide, except for test 18 with the Hanford soil sample where $88.7 \%$ immobilization was observed (see Table 2). The latter test indicates that treatment efficiency may be somewhat lower in very dry soils, although the target performance goal appears to be readily attainable.

Chromium was not remobilized in any of the leach tests performed on the contaminated soils following gas treatment. This strongly suggests that the treatment process is irreversible for this constituent, although the leach test runs were only a week in duration. Irreversibility of the treatment process is consistent with the known chemical behavior of chromium in natural environments (WHC 1993a). 
Test results obtained from leaching of uranium-contaminated/untreated Hanford and Fernald soils indicate that uranium mobility is strongly dependent on soil chemistry. Thus, an immobilization factor of $30.5 \%$ was obtained in test 3 with the Hanford soil, whereas a factor of $98.4 \%$ was obtained in test 15 with the Fernald soil. These results suggest that uranium mobility is related to the amount of organic matter present in a soil. Thus, uranium appeared to be essentially immobile in the organic-rich Fernald soil sample but significantly mobile in the leaner and more oxidized Hanford soil sample.

Data associated with the Hanford soil treatment tests indicate that uranium was not irreversibly immobilized, as revealed by the gradual release of uranium over the duration of the leach tests. This behavior suggests that $U(V I)$ was reduced to insoluble $U(I V)$ by treatment with hydrogen sulfide but was subsequently reoxidized during leaching by oxygen dissolved in the groundwater leachate. The treatment tests conducted with the uranium-contaminated Fernald soil sample exhibited a lower solubility of uranium during leaching. It appears that immobilization of uranium during the latter tests is primarily due to the organic materials associated with the Fernald soil, which serve to maintain a reducing condition during the leaching stage.

The results of the testing activities presented here indicate that a $100 \mathrm{ppm}$ mixture of hydrogen sulfide in an inert carrier gas is effective in remediation of $\mathrm{Cr}(\mathrm{VI})$ contaminated soil (i.e., immobilization of $>90 \%$ of chromate present). These results also indicate that a treatment period of several days at this concentration is sufficient time for the immobilization reaction to approach completion. Addition of a sufficient amount of hydrogen sulfide to a contaminated soil to attain a mole ratio of $\mathrm{S}: \mathrm{Cr}(\mathrm{VI})$ of 10:1 appears to be adequate. Previous testing activities have indicated that application of a $2700 \mathrm{ppm} \mathrm{H}_{2} \mathrm{~S}$ gas mixture at a molar ratio of $\mathrm{S}: \mathrm{Cr}(\mathrm{VI})$ of 20 results in about $95 \%$ immobilization within a.period of minutes (Thornton et al. 1991). Thus reaction kinetics or hydrogen sulfide concentration levels do not appear to be limiting factors in treatment. The primary requirement, rather, is the introduction of a sufficient amount of hydrogen sulfide to attain a mole ratio of 10 or greater. Attainment of this ratio, however, may require several days if lower concentrations of hydrogen sulfide are utilized since the total mass of hydrogen sulfide delivered to the soil is a function of gas concentration and flow rate.

It is a general requirement of soil remediation activities that application of a specific method not result in significant alteration or degradation of soil properties and that hazardous byproducts are not generated. The results obtained in this study indicate that soil chemistry is not grossly affected by the gas treatment process. The measured $\mathrm{pH}$ of the leachates of the treated soils was essentially identical to that of the untreated soils. A minor amount of sulfate was observed in the leachate samples of treated soils, and in several cases trace manganese was observed. The latter two constituents are generally not considered to be of major environmental concern. Significant concentrations of metals other than chromium, uranium, and manganese were not observed in any leachate samples associated with the treated soils. It was noted, however, that nitrite was detected in several tests involving gas treatment of nitrate-contaminated Fernald soil. This observation suggests that hydrogen sulfide treatment may result in the generation of nitrite in certain organic or clay-rich soils that are contaminated with nitrate.

A wide variation in soil cleanup standards exists between individual Superfund sites. Booth and Jacobson (1992) reported that the soil cleanup standard for chromium varied from 3.7 to $62.7 \mathrm{ppm}$ in a review of 34 soil sites, only 20 of which had specific numerical cleanup standards. They suggest that this variation can be attributed to differences in cleanup goals, sitespecific conditions (e.g., potential future site use), and the sensitivity of primary receptors. It is 
clear that the selection of a performance goal associated with application of the gas treatment approach must be made on a site-specific basis in consultation with regulatory staff familiar with the site.

The Toxic Characteristics Leach Procedure (TCLP), however, has received widespread acceptance as a means of assessing the effectiveness of various remediation approaches. This procedure is similar to the water leaching approach presented here, although the TCLP employs a buffered, mildly acidic leaching solution (Method 1311 of EPA 1992). Regulatory levels have been established by EPA for 39 chemicals at or above which a waste is defined by the TCLP as a characteristic hazardous waste (Newton 1990). The regulatory level for chromium is $5.0 \mathrm{mg} / \mathrm{L}$, in the leachate, where the total amount of the extraction fluid is equal to 20 times the weight of the solid phase. This implies that a soil could be considered as a characteristic waste if it contains about $100 \mathrm{ppm}$ leachable chromium. The testing results presented here indicate that the hydrogen sulfide treatment approach should generate results satisfying the TCLP criteria for many chromate contaminated soils, assuming that the TCLP has similar extraction efficiencies to the water-leaching approach employed here. A comparison of extraction tests performed on chromate contaminated soils by DeYong et al. (1990) indicates that similar recoveries can be expected for many soil types when using either approach.

\subsection{FUTURE WORK}

Laboratory results obtained to date suggest that in situ treatment of soils contaminated with metals or selected radionuclides using reactive gas mixtures is technically feasible. Soil treatment could be undertaken at a waste site by injection of a diluted hydrogen sulfide gas mixture into a central borehole, as illustrated in Figure 13. A system of extraction wells, arranged along the periphery of the site, would permit removal of excess agent and provide control of the movement of the gases through the site. In addition, gradual diffusion of gases from the unsaturated zone into the underlying saturated zone could provide a means for treatment of the entire contaminant migration pathway. An impermeable cover placed over the site would serve to minimize the escape of treatment gas from the soils to the atmosphere.

Treatment gas would be recirculated through the site in a multipass continuous flow process until soil treatment approached completion. The approximate length of time required to achieve this can be predicted on the basis of soil contaminant levels, flow cell dimensions, and gas concentrations and flow rates. Analysis of the gas effluent stream could also be performed as a means of determining the onset of hydrogen sulfide breakthrough, thus indicating treatment completion (see Figure 13c). Air would be circulated through the site at the end of the treatment period to purge residual hydrogen sulfide from the soil. Subsequent to treatment, soil samples could be taken at various points to verify that the site was treated in a homogeneous manner and the required degree of contaminant immobilization was achieved.

Planning activities associated with the performance of a field demonstration as described above have been initiated. Primary objectives for the coming year (FY 1994) include selection of a test waste site and performance of verification bench scale treatment tests on representative contaminated soil samples from the site. These tests will serve to verify that the gas treatment approach is effective for "aged" contaminated soil samples and for the specific contaminant phases associated with the site. Solids characterization work will also be conducted in conjunction with these tests and will include determination of soil chemistry and characteristics of the untreated soil, identification of the specific waste forms present, and description of 
WHC-EP-0694

(a)

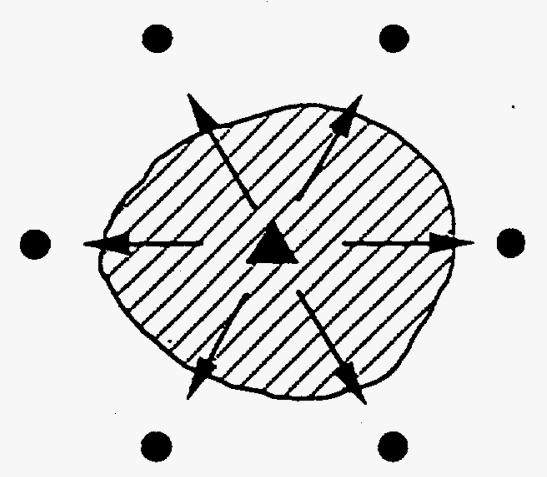

$$
\begin{aligned}
& d=\begin{array}{l}
\text { depth of contamination } \\
(10-40 \text { feet })
\end{array} \\
& r=\text { radius of influence }(\sim 10 \text { feet })
\end{aligned}
$$

A treatment gas injection well

- treatment gas extraction well
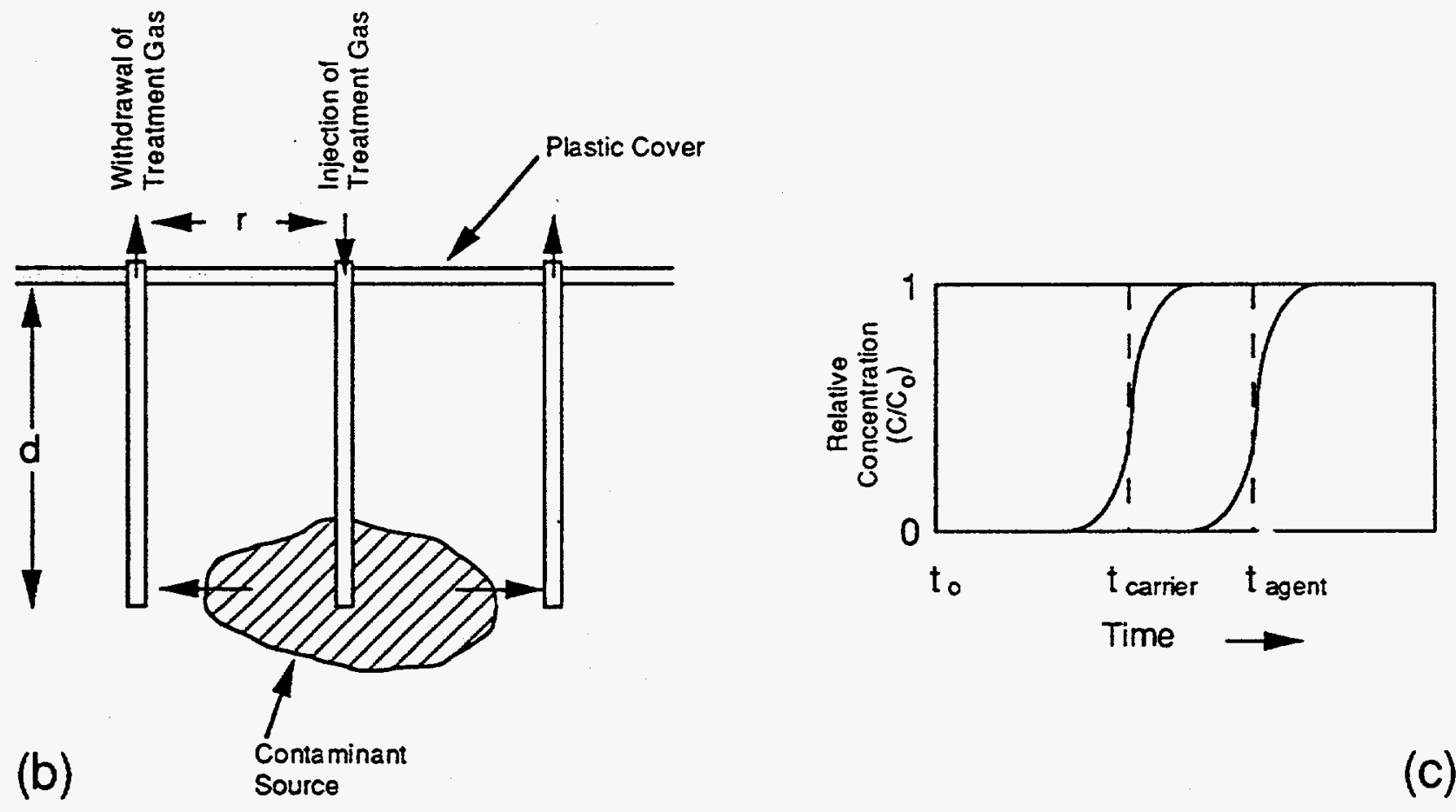

Figure 13. Proposed Injection and Extraction Well Pattern Configuration. (a) and (b) A treatment agent is introduced into the injection well as a gas. The treatment gas is drawn through the contaminated zone by a vacuum applied to the extraction wells. (c) The active treatment gas constituent will arrive at an extraction well at some time $t_{\text {agent }}$ subsequent to arrival of inert constituents, such as nitrogen, which will arrive at time $t_{\text {carrier }}$. 
treatment products and properties of the treated soil.

Major design changes in the laboratory-scale testing system are planned for FY 1994. Electronic mass flow controllers will be utilized for gas blending operations during the tests described above, thus minimizing variations in gas flow rates. Electrochemical sensors will be utilized to monitor actual gas concentrations utilized during testing. Gas concentration data will be electronically recorded using a data logger and computer. Measurements of changes in gas concentration across the soil column thus can be obtained during treatment and will be used as a means of determining gas breakthrough characteristics. It is anticipated that this data will provide a means of identifying optimal gas concentrations and better estimating the minimum required treatment period.

Another important area of technical activity for FY 1994 is the performance of design and scale-up activities associated with the development of a treatment system for field applications. Important aspects of system design include development of equipment that will automate gas mixing and flow operations, monitoring of gas composition, and recording of major system parameters. Options for disposal or reuse of hydrogen sulfide will be evaluated. An important aspect of the latter is identification of a method for elimination of diluent soil gases that will be introduced into the gas treatment stream during system operations. Evaluation of system requirements associated with full-scale operations will also be undertaken using principles of dimensional analysis and gas flow modeling, and the appropriate system components will be obtained or assembled.

Larger scale laboratory tests will be conducted as part of the scale-up process associated with system development. These tests will be designed to evaluate the treatment of a significant volume of contaminated soil and will involve injection of the treatment gas into the soil through a central injection point and extraction through an array of points arranged in a radial configuration about the injection point, as presented in Figure 13. This system will be configured so that the treatment gas mixture is recirculated through the soil until the treatment process is completed. Analysis of the gas effluent stream will be performed during the tests as a means of determining the onset of hydrogen sulfide breakthrough (see Figure 13[c]). Subsequent to treatment, the soil will be sampled at various points to verify that the laboratory test volume has been treated in a homogeneous manner and that the required degree of contaminant immobilization has been attained.

A field demonstration of the gas treatment approach is anticipated to take place in FY 1995 or FY 1996. In addition to the technical activities described above, discussions will be conducted with site staff to identify regulatory and safety requirements associated with the demonstration. Preliminary considerations suggest that this approach is acceptable provided adequate control of treatment gas is maintained during application and residual gas can be removed from the site. The results of the testing activities presented in this study indicate that relatively dilute hydrogen sulfide mixtures should be effective in bringing about chromium, and possibly uranium, immobilization. It is also unlikely that significant amounts of hazardous byproducts will be generated by this treatment approach. Other issues that will need to be addressed in conjunction with development of a treatment permit include specification of an acceptable level of residual treatment gas that can be left in the soil following completion of the demonstration and determination of soil remediation performance goals. 


\subsection{CONCLUSIONS}

Soil treatment test results demonstrate that hydrogen sulfide can provide adequate treatment of soils contaminated with $\mathrm{Cr}(\mathrm{VI})$ and $\mathrm{U}(\mathrm{VI})$ at the $200 \mathrm{ppm}$ level. These tests involved three different soils, indicating that soil chemistry is not a critical factor in application of this approach to soil remediation activities. Treatment of the soils was performed using $100 \mathrm{ppm}$ and $2000 \mathrm{ppm}$ concentrations of hydrogen sulfide in nitrogen at a mole ratio of $\mathrm{S}:(\mathrm{Cr}+\mathrm{U})$ that ranged from 7 to 10 . In general, $>90 \%$ immobilization of chromium and $>50 \%$ immobilization of uranium was achieved, as determined by water leach tests conducted on the soils following treatment. Leach test results indicate that the treatment process is essentially irreversible for chromium but partially reversible for uranium.

Several tests were also conducted with soils contaminated to $5000 \mathrm{ppm}$ with nitrate. The presence of nitrate did not significantly affect treatment results. Nitrite was not observed in two sandy soils having a low content of organic matter but was detected in leachate samples associated with the hydrogen sulfide treatment of an organic-rich soil containing clay. Comparison of other leachate parameters suggests that no other potentially hazardous products were generated by the treatment process and that soil alteration was minimal.

A series of three tests was conducted on a contaminated soil at three different soil moisture content levels (i.e., dry, native, and moderately wet). The results of these tests suggest that treatment effectiveness is somewhat lower in very dry soils but is still capable of immobilizing chromium and uranium to an acceptable degree.

The results obtained from these tests indicate that soils contaminated with hexavalent chromium and/or uranium can be treated with a gas mixture containing $100 \mathrm{ppm}$ hydrogen sulfide applied at a mole ratio of $\mathrm{S}:(\mathrm{Cr}+\mathrm{U})$ of 10 . These tests also demonstrate that the concentration of hydrogen sulfide in the gas mixture is not a limiting factor in the treatment of contaminated soils, although the length of the treatment period required increases as the concentration of the treatment gas is reduced. The potential for using very dilute gas mixtures is a favorable factor for employing hydrogen sulfide, a highly toxic gas, since it reduces safety concerns significantly. 
WHC-EP-0694 


\subsection{REFERENCES}

40 CFR 143, 1991, "National Secondary Drinking Water Regulations," Code of Federal Regulations, as amended.

Booth, P.N. and M.A. Jacobson, 1992, Development of Cleanup Standards at Superfund Sites: An Evaluation of Consistency, J. Air Waste Manage. Assoc., v.42, p.762-766.

Browman, M.G., and B.P. Spalding, 1984, Reduction of Radiostrontium Mobility in Acid Soils by Carbonate Treatment, J. Env. Quality, v.13, p.166-172.

Czupyrna, G., R.D. Levy, A.I. MacLean, and H. Gold, 1989, In Situ Immobilization of HeavyMetal-Contaminated Soils, Pollution Technology Review No. 173, Noyes Data Corporation, Park Ridge, New Jersey, 155 pp.

DeYong, G.D., B.K. Bowden, R.S. Harl, and R.J. Anglin, 1990, Determination of Hexavalent Chromium in Soil Samples, Superfund '90, Proceedings of the 11th National Conference, 26-28 Nov 1990, Washington, D.C.

EPA, 1985, Remedial Action at Waste Disposal Sites, EPA/25/6-85/006, U.S. Environmental Protection Agency, Washington, D.C.

EPA, 1990, Handbook on In Situ Treatment of Hazardous Waste-Contaminated Soils, EPA540/2-90/002, Risk Reduction Engineering Laboratory, Office of Research and Development, U.S. Environmental Protection Agency, Cincinnati, Ohio.

EPA, 1992, Test Methods for Evaluating Solid Waste - Physical/Chemical Methods, SW-846, Method 1311, Toxicity Characteristic Leaching Procedure (revision 0, July 1992), U.S. Environmental Protection Agency, Washington, D.C.

Garrels, R.M., and C.L. Christ, 1965, Solutions, Minerals, and Equilibria, Harper \& Row, New York, $450 \mathrm{pp}$.

Ghassemi, M., 1988, In Situ Technologies for Site Remediation, 1988 DOE Model Conference Proceedings, v.3, p.699-708.

Kim, K.H., J.T. Ammons, and S.Y. Lee, 1990, Immobilization of Radioactive Strontium in Contaminated Soils by Phosphate Treatment, 14. Nuclear Waste Management Conference, 26-29 Nov 1990, Boston, Massachusetts.

Langmuir, D., 1978, Uranium Solution-Mineral Equilibria at Low Temperatures with Applications to Sedimentary Ore Deposits, Geochem. Cosmochim. Acta, v.42, p.547-569.

Newton, J., 1990, Understanding the Toxicity Characteristic Rule, Pollution Engineering, v.22, p.90-98.

Sax, N.I. and R.J. Lewis, Sr., 1989, Dangerous Properties of Industrial Materials, Seventh ed., Van Nostrand Reinhold, New York. 
Smith, M.A., 1985, Contaminated Land-Reclamation and Treatment, Plenum Press, New York, 433pp.

Thornton, E.C., C.A. Jurgensmeier, and M.A. Baechler, 1991, Laboratory Evaluation of the In Situ Chemical Treatment Approach for Remediation of $\mathrm{Cr}(\mathrm{VI})$-Contaminated Soils and Groundwater, WHC-SP-0704, Westinghouse Hanford Company, Richland, Washington.

WAC 173-340, 1990, The Model Toxics Control Act Cleanup Regulations, Washington Administrative Code, as amended.

WHC, 1988, Environmental Compliance Manual, WHC-CM-7-5, Westinghouse Hanford Company, Richland, Washington.

WHC, 1990, Geotechnical Engineering Procedure Manual, WHC-IP-0635, Westinghouse Hanford Company, Richland, Washington.

WHC, 1993a, Fate and Transport of Chromium in the Environment, WHC-SD-EN-ES-035, prepared by E.C. Thornton, Westinghouse Hanford Company, Richland, Washington.

WHC, 1993b, Test Plan - Gas Treatment and Column Leach Testing of Chromate, Uranium (VI), and Nitrate-Contaminated Soil, WHC-SD-EN-TP-019, prepared by E.C. Thornton, C.H. Delegard, M.A. Baechler, and M.A. Beck, Westinghouse Hanford Company, Richland, Washington. 
WHC-EP-0694

APPENDIX A

LEACHATE ANALYTICAL DATA AND SOIL MOISTURE CONTENTS 
WHC-EP-0694

A-ii 
TEST \#1 (3-0744)

soil type: Hanford

moisture content: $5.82 \%$

contaminants: none

$\mathrm{H}_{2} \mathrm{~S}$ concentration: not treated

leachate: groundwater

\begin{tabular}{||l|l|l|l|l|l|l|l|l||}
\hline Sample \# & $\mathrm{pH}$ & $\mathrm{U}, \mathrm{ppm}$ & $\begin{array}{l}\mathrm{Cr}(\mathrm{Vl}), \\
\mathrm{ppm}\end{array}$ & $\begin{array}{l}\Sigma \mathrm{Cr}, \\
\mathrm{ppm}\end{array}$ & $\begin{array}{l}\mathrm{NO}_{3,} \\
\mathrm{ppm}\end{array}$ & $\begin{array}{l}\mathrm{NO}_{2,} \\
\mathrm{ppm}\end{array}$ & $\begin{array}{l}\mathrm{Cl}, \\
\mathrm{ppm}\end{array}$ & $\begin{array}{l}\mathrm{SO}_{4 \prime} \\
\mathrm{ppm}\end{array}$ \\
\hline $3-0744-1$ & $\mathbf{8 . 3 5}$ & $<0.00526$ & $<0.05$ & 0.025 & 54.7 & $<2.5$ & 4.35 & 103.1 \\
\hline $3-0744-2$ & 8.45 & $<0.00385$ & - & 0.016 & 4.96 & $<2.5$ & 3.60 & 20.3 \\
\hline $3-0744-3$ & $\mathbf{8 . 2 6}$ & $<0.00435$ & $<0.05$ & $<0.013$ & 4.44 & $<2.5$ & 3.29 & 20.0 \\
\hline $3-0744-4$ & $\mathbf{8 . 4 5}$ & $<0.00400$ & $<0.05$ & 0.021 & 4.05 & $<2.5$ & 3.07 & 20.1 \\
\hline
\end{tabular}

Note: Aqueous concentrations reported in ppm refer to units of $\mathrm{mg} / \mathrm{L}$. $\Sigma \mathrm{Cr}$ refers to total chromium concentration as determined by ICP analysis while $\mathrm{Cr}(\mathrm{VI})$ refers to hexavalent chromium concentration as determined by spectrophotometric analysis.

TEST \#2 (3-0745)

soil type: Hanford

moisture content: $5.82 \%$

contaminants: none

$\mathrm{H}_{2} \mathrm{~S}$ concentration: $2000 \mathrm{ppm}$

leachate: groundwater

\begin{tabular}{||l|l|l|l|l|l|l|l|l||}
\hline Sample \# & $\mathrm{pH}$ & $\mathrm{U}, \mathrm{ppm}$ & $\begin{array}{l}\mathrm{Cr}(\mathrm{VI}), \\
\mathrm{ppm}\end{array}$ & $\begin{array}{l}\mathrm{\Sigma Cr}, \\
\mathrm{ppm}\end{array}$ & $\begin{array}{l}\mathrm{NO}_{3}, \\
\mathrm{ppm}\end{array}$ & $\begin{array}{l}\mathrm{NO}_{2,} \\
\mathrm{ppm}\end{array}$ & $\begin{array}{l}\mathrm{Cl}, \\
\mathrm{ppm}\end{array}$ & $\begin{array}{l}\mathrm{SO}_{4}, \\
\mathrm{ppm}\end{array}$ \\
\hline $3-0745-1$ & 8.51 & $<0.00500$ & $<0.05$ & $<0.013$ & 33.8 & $<2.5$ & 3.92 & 213 \\
\hline $3-0745-2$ & 8.43 & $<0.00385$ & $<0.05$ & $<0.013$ & $<2.9$ & $<2.5$ & 3.00 & 42.3 \\
\hline $3-0745-3$ & 8.47 & $<0.00400$ & $<0.05$ & $<0.013$ & $<2.9$ & $<2.5$ & 3.09 & 40.5 \\
\hline $3-0745-4$ & 8.47 & 0.00333 & $<0.05$ & $<0.013$ & $<2.9$ & $<2.5$ & 2.90 & 39.2 \\
\hline
\end{tabular}


TEST \#3 (3-0746)

soil type: Hanford

moisture content: $5.11 \%$

contaminants: $200 \mathrm{ppm} \mathrm{Cr}(\mathrm{VI}) / 200 \mathrm{ppm} \mathrm{U}(\mathrm{VI}) / 100 \mathrm{ppm} \mathrm{NO}{ }_{3}^{-}$

$\mathrm{H}_{2} \mathrm{~S}$ concentration: not treated

leachate: groundwater

\begin{tabular}{||l|l|l|l|l|l|l|l|l||}
\hline \hline Sample \# & $\mathrm{pH}$ & $\mathrm{U}, \mathrm{ppm}$ & $\begin{array}{l}\mathrm{Cr}(\mathrm{VI}), \\
\mathrm{ppm}\end{array}$ & $\begin{array}{l}\Sigma \mathrm{Cr}, \\
\mathrm{ppm}\end{array}$ & $\begin{array}{l}\mathrm{NO}_{3 \prime} \\
\mathrm{ppm}\end{array}$ & $\begin{array}{l}\mathrm{NO}_{2,} \\
\mathrm{ppm}\end{array}$ & $\begin{array}{l}\mathrm{Cl}, \\
\mathrm{ppm}\end{array}$ & $\begin{array}{l}\mathrm{SO}_{4}, \\
\mathrm{ppm}\end{array}$ \\
\hline $3-0746-1$ & 8.27 & 216 & 282 & 272 & 265 & $<2.5$ & 6.80 & 99.2 \\
\hline $3-0746-2$ & 8.97 & 56.0 & 1.98 & 2.03 & 4.99 & $<2.8$ & 2.72 & 20.4 \\
\hline $3-0746-3$ & 8.87 & 42.9 & 1.27 & 1.25 & 4.52 & $<2.6$ & 2.93 & 20.0 \\
\hline $3-0746-4$ & 8.87 & 25.4 & 0.72 & 0.74 & 4.27 & $<2.6$ & 2.84 & 19.3 \\
\hline
\end{tabular}

TEST \#4 (3-0747)

soil type: Hanford

moisture content: $5.11 \%$

contaminants: $200 \mathrm{ppm} \mathrm{Cr}(\mathrm{VI}) / 200 \mathrm{ppm} \mathrm{U}(\mathrm{VI}) / 100 \mathrm{ppm} \mathrm{NO}{ }^{-}$

$\mathrm{H}_{2} \mathrm{~S}$ concentration: $2000 \mathrm{ppm}$

leachate: groundwater

\begin{tabular}{||l|l|l|l|l|l|l|l|l||}
\hline Sample \# & $\mathrm{pH}$ & $\mathrm{U}, \mathrm{ppm}$ & $\begin{array}{l}\mathrm{Cr}(\mathrm{VI}), \\
\mathrm{ppm}\end{array}$ & $\begin{array}{l}\Sigma \mathrm{Cr}_{1} \\
\mathrm{ppm}\end{array}$ & $\begin{array}{l}\mathrm{NO}_{3,}, \\
\mathrm{ppm}\end{array}$ & $\begin{array}{l}\mathrm{NO}_{2,} \\
\mathrm{ppm}\end{array}$ & $\begin{array}{l}\mathrm{Cl}_{1}, \\
\mathrm{ppm}\end{array}$ & $\begin{array}{l}\mathrm{SO}_{4}, \\
\mathrm{ppm}\end{array}$ \\
\hline $3-0747-1$ & 8.47 & 124 & 32.6 & 19.3 & 361 & $<2.5$ & 4.13 & 193 \\
\hline $3-0747-2$ & 8.87 & 47.8 & 0.21 & 0.44 & 4.81 & $<2.8$ & 2.89 & 30.2 \\
\hline $3-0747-3$ & 8.77 & 41.4 & 0.13 & 0.25 & 4.69 & $<2.6$ & 3.16 & 37.1 \\
\hline $3-0747-4$ & 8.87 & 36.5 & 0.07 & 0.15 & $<3.5$ & $<2.4$ & 2.86 & 48.0 \\
\hline
\end{tabular}


TEST \#5 (3-0748)

soil type: Hanford

moisture content: $4.30 \%$

contaminants: $200 \mathrm{ppm} \mathrm{Cr}(\mathrm{VI}) / 200 \mathrm{ppm} \mathrm{U}(\mathrm{VI}) / 100 \mathrm{ppm} \mathrm{NO}_{3}^{-}$

$\mathrm{H}_{2} \mathrm{~S}$ concentration: $100 \mathrm{ppm}$

leachate: groundwater

\begin{tabular}{||l|l|l|l|l|l|l|l|l||}
\hline \hline Sample \# & $\mathrm{pH}$ & $\mathrm{U}, \mathrm{ppm}$ & $\begin{array}{l}\mathrm{Cr}(\mathrm{VI}), \\
\mathrm{ppm}\end{array}$ & $\begin{array}{l}\Sigma \mathrm{Cr}, \\
\mathrm{ppm}\end{array}$ & $\begin{array}{l}\mathrm{NO}_{3 \prime} \\
\mathrm{ppm}\end{array}$ & $\begin{array}{l}\mathrm{NO}_{2,} \\
\mathrm{ppm}\end{array}$ & $\begin{array}{l}\mathrm{Cl}, \\
\mathrm{ppm}\end{array}$ & $\begin{array}{l}\mathrm{SO}_{4 \prime} \\
\mathrm{ppm}\end{array}$ \\
\hline $3-0748-1$ & 8.37 & 78.2 & 15.7 & 15.7 & 625 & 2.45 & 7.80 & 327 \\
\hline $3-0748-2$ & 8.67 & 52.2 & 0.34 & 0.47 & 6.13 & $<2.4$ & 2.95 & 27.7 \\
\hline $3-0748-3$ & 8.77 & 46.8 & 0.12 & 0.13 & 4.55 & $<2.6$ & 3.13 & 32.9 \\
\hline $3-0748-4$ & 8.77 & 35.1 & $<0.05$ & 0.095 & $<3.5$ & $<2.6$ & 2.74 & 51.3 \\
\hline
\end{tabular}

TEST \#6 (3-0749)

soil type: Hanford

moisture content: $5.76 \%$

contaminants: $200 \mathrm{ppm} \mathrm{Cr}(\mathrm{Vl}) / 200 \mathrm{ppm} \mathrm{U}(\mathrm{VI}) / 5000 \mathrm{ppm} \mathrm{NO}_{3}{ }^{\circ}$

$\mathrm{H}_{2} \mathrm{~S}$ concentration: $2000 \mathrm{ppm}$

leachate: groundwater

\begin{tabular}{|l|l|l|l|l|l|l|l|l||}
\hline Sample \# & $\mathrm{pH}$ & $\mathrm{U}, \mathrm{ppm}$ & $\begin{array}{l}\mathrm{Cr}(\mathrm{VI}), \\
\mathrm{ppm}\end{array}$ & $\begin{array}{l}\Sigma \mathrm{Cr}, \\
\mathrm{ppm}\end{array}$ & $\mathrm{NO}_{3,} \mathrm{ppm}$ & $\begin{array}{l}\mathrm{NO}_{2 \prime} \\
\mathrm{ppm}\end{array}$ & $\begin{array}{l}\mathrm{Cl}, \\
\mathrm{ppm}\end{array}$ & $\begin{array}{l}\mathrm{SO}_{4 \prime} \\
\mathrm{ppm}\end{array}$ \\
\hline $3-0749-1$ & 7.78 & 131 & 23.1 & 16.6 & 11120 & $<28.5$ & 9.00 & 102.8 \\
\hline $3-0749-2$ & 8.17 & 102 & 7.54 & 7.61 & 2420 & $<14.4$ & 7.52 & 254 \\
\hline $3-0749-3$ & 8.97 & 44.3 & 0.47 & 0.47 & 13.1 & $<2.4$ & 2.71 & 63.9 \\
\hline $3-0749-4$ & 9.17 & 23.8 & 0.22 & 0.22 & 7.84 & $<2.4$ & 2.93 & 51.8 \\
\hline
\end{tabular}


TEST \#7 (3-0750)

soil type: Hanford

moisture content: $5.76 \%$

contaminants: 200 ppm $\mathrm{Cr}(\mathrm{VI}) / 200 \mathrm{ppm} \mathrm{U}(\mathrm{VI}) / 5000 \mathrm{ppm} \mathrm{NO}$

$\mathrm{H}_{2} \mathrm{~S}$ concentration: $100 \mathrm{ppm}$

leachate: groundwater

\begin{tabular}{||l|l|l|l|l|l|l|l|l||}
\hline Sample \# & $\mathrm{pH}$ & $\mathrm{U}, \mathrm{ppm}$ & $\begin{array}{l}\mathrm{Cr}(\mathrm{VI}), \\
\mathrm{ppm}\end{array}$ & $\begin{array}{l}\Sigma \mathrm{Cr}, \\
\mathrm{ppm}\end{array}$ & $\mathrm{NO}_{3}, \mathrm{ppm}$ & $\begin{array}{l}\mathrm{NO}_{2,} \\
\mathrm{ppm}\end{array}$ & $\begin{array}{l}\mathrm{Cl}, \\
\mathrm{ppm}\end{array}$ & $\begin{array}{l}\mathrm{SO}_{4,} \\
\mathrm{ppm}\end{array}$ \\
\hline $3-0750-1$ & 7.98 & 86.6 & 30.0 & 25.8 & 13960 & $<2.9$ & 10.2 & 99.0 \\
\hline $3-0750-2$ & 7.87 & 138 & 13.9 & 14.1 & 5854 & $<14.4$ & 7.98 & 174.5 \\
\hline $3-0750-3$ & 8.77 & 77.2 & 2.89 & 2.95 & 209 & $<2.4$ & 2.81 & 63.3 \\
\hline $3-0750-4$ & 8.97 & 32.2 & 0.25 & 0.34 & 10.4 & $<2.6$ & 2.84 & 54.9 \\
\hline
\end{tabular}

TEST \#8 (3-0751)

soil type: Sandia

moisture content: $5.59 \%$

contaminants: none

$\mathrm{H}_{2} \mathrm{~S}$ concentration: not treated

leachate: deionized water

\begin{tabular}{||l|l|l|l|l|l|l|l|l||}
\hline \hline Sample \# & $\mathrm{pH}$ & $\mathrm{U}, \mathrm{ppm}$ & $\begin{array}{l}\mathrm{Cr}(\mathrm{Vl}), \\
\mathrm{ppm}\end{array}$ & $\begin{array}{l}\Sigma \mathrm{Cr}_{,} \\
\mathrm{ppm}\end{array}$ & $\begin{array}{l}\mathrm{NO}_{3 \prime} \\
\mathrm{ppm}\end{array}$ & $\begin{array}{l}\mathrm{NO}_{2}, \\
\mathrm{ppm}\end{array}$ & $\begin{array}{l}\mathrm{Cl}_{,}, \\
\mathrm{ppm}\end{array}$ & $\begin{array}{l}\mathrm{SO}_{4,} \\
\mathrm{ppm}\end{array}$ \\
\hline $3-0751-1$ & 8.14 & $<0.00588$ & $<0.05$ & $<0.013$ & 9.04 & $<2.5$ & 4.42 & 90.4 \\
\hline $3-0751-2$ & 8.33 & $<0.00435$ & $<0.05$ & $<0.013$ & $<2.9$ & $<2.5$ & 0.85 & 9.58 \\
\hline $3-0751-3$ & 8.17 & $<0.00435$ & $<0.05$ & $<0.013$ & $<2.9$ & $<2.5$ & 0.80 & 5.77 \\
\hline $3-0751-4$ & 8.19 & $<0.00435$ & $<0.05$ & $<0.013$ & $<2.9$ & $<2.5$ & 0.59 & 3.90 \\
\hline
\end{tabular}


TEST \#9 (3-0752)

soil type: Sandia

moisture content: $5.59 \%$

contaminants: none

$\mathrm{H}_{2} \mathrm{~S}$ concentration: $2000 \mathrm{ppm}$

leachate: deionized water

\begin{tabular}{||l|l|l|l|l|l|l|l|l||}
\hline Sample \# & $\mathrm{pH}$ & $\mathrm{U}, \mathrm{ppm}$ & $\begin{array}{l}\mathrm{Cr}(\mathrm{VI}), \\
\mathrm{ppm}\end{array}$ & $\begin{array}{l}\Sigma \mathrm{Cr}, \\
\mathrm{ppm}\end{array}$ & $\begin{array}{l}\mathrm{NO}_{3 \prime}, \\
\mathrm{ppm}\end{array}$ & $\begin{array}{l}\mathrm{NO}_{2 \prime} \\
\mathrm{ppm}\end{array}$ & $\begin{array}{l}\mathrm{Cl}, \\
\mathrm{ppm}\end{array}$ & $\begin{array}{l}\mathrm{SO}_{4 \prime} \\
\mathrm{ppm}\end{array}$ \\
\hline $3-0752-1$ & $\mathbf{8 . 5 6}$ & $<0.00556$ & $<0.05$ & $<0.013$ & 6.45 & $<2.5$ & 4.13 & 139.2 \\
\hline $3-0752-2$ & $\mathbf{8 . 2 1}$ & $<0.00455$ & $<0.05$ & $<0.013$ & $<2.9$ & $<2.5$ & 0.73 & 24.9 \\
\hline $3-0752-3$ & $\mathbf{8 . 1 7}$ & $<0.00625$ & $<0.05$ & $<0.013$ & $<2.9$ & $<2.5$ & 0.87 & 16.8 \\
\hline $3-0752-4$ & $\mathbf{8 . 1 3}$ & $<0.00435$ & $<0.05$ & $<0.013$ & $<2.9$ & $<2.5$ & 0.56 & 13.0 \\
\hline
\end{tabular}

TEST \#10 (3-0753)

soil type: Sandia

moisture content: $9.14 \%$

contaminants: $200 \mathrm{ppm} \mathrm{Cr}(\mathrm{VI})$

$\mathrm{H}_{2} \mathrm{~S}$ concentration: not treated

leachate: deionized water

\begin{tabular}{||l|l|l|l|l|l|l|l|l||}
\hline Sample \# & $\mathrm{pH}$ & $\mathrm{U}, \mathrm{ppm}$ & $\mathrm{Cr}(\mathrm{VI}), \mathrm{ppm}$ & $\Sigma \mathrm{Cr}, \mathrm{ppm}$ & $\begin{array}{l}\mathrm{NO}_{3 \prime} \\
\mathrm{ppm}\end{array}$ & $\begin{array}{l}\mathrm{NO}_{2,} \\
\mathrm{ppm}\end{array}$ & $\begin{array}{l}\mathrm{Cl}, \\
\mathrm{ppm}\end{array}$ & $\begin{array}{l}\mathrm{SO}_{4 \prime} \\
\mathrm{ppm}\end{array}$ \\
\hline $3-0753-1$ & 7.97 & 18.4 & 307 & 315 & 62.4 & $<2.6$ & 31.3 & 122.6 \\
\hline $3-0753-2$ & 8.14 & 0.00118 & 3.53 & 3.23 & $<3.5$ & $<2.6$ & 0.68 & 10.7 \\
\hline $3-0753-3$ & 8.07 & $<0.00098$ & 0.43 & 0.43 & $<3.5$ & $<2.6$ & $<0.40$ & 6.0 \\
\hline $3-0753-4$ & 8.18 & $<0.00098$ & 0.122 & 0.135 & $<3.5$ & $<2.6$ & $<0.40$ & $<3.5$ \\
\hline
\end{tabular}


TEST \#11 (3-0754)

soil type: Sandia

moisture content: $9.14 \%$

contaminants: $200 \mathrm{ppm} \mathrm{Cr}(\mathrm{VI})$

$\mathrm{H}_{2} \mathrm{~S}$ concentration: $2000 \mathrm{ppm}$

leachate: deionized water

\begin{tabular}{||l|l|l|l|l|l|l|l|l||}
\hline Sample \# & $\mathrm{pH}$ & $\mathrm{U}, \mathrm{ppm}$ & $\begin{array}{l}\mathrm{Cr}(\mathrm{VI}), \\
\mathrm{ppm}\end{array}$ & $\begin{array}{l}\Sigma \mathrm{Cr}, \\
\mathrm{ppm}\end{array}$ & $\begin{array}{l}\mathrm{NO}_{3 \prime} \\
\mathrm{ppm}\end{array}$ & $\begin{array}{l}\mathrm{NO}_{2 \prime} \\
\mathrm{ppm}\end{array}$ & $\begin{array}{l}\mathrm{Cl}, \\
\mathrm{ppm}\end{array}$ & $\begin{array}{l}\mathrm{SO}_{4}, \\
\mathrm{ppm}\end{array}$ \\
\hline $3-0754-1$ & 8.13 & 3.5 & 32.9 & - & 65.0 & $<2.4$ & 35.3 & 191.3 \\
\hline $3-0754-2$ & 7.95 & $<0.00098$ & 2.54 & 2.35 & $<3.5$ & $<2.4$ & 0.40 & 38.8 \\
\hline $3-0754-3$ & 8.02 & 0.013 & $<0.05$ & $<0.03$ & $<3.5$ & $<2.4$ & $<0.40$ & 25.3 \\
\hline $3-0754-4$ & 8.10 & $<0.00098$ & $<0.05$ & $<0.03$ & $<3.5$ & $<2.4$ & $<0.40$ & 17.0 \\
\hline
\end{tabular}

TEST \#12 (3-0755)

soil type: Sandia

moisture content: $8.21 \%$

contaminants: $200 \mathrm{ppm} \mathrm{Cr}(\mathrm{VI})$

$\mathrm{H}_{2} \mathrm{~S}$ concentration: $100 \mathrm{ppm}$

leachate: deionized water

\begin{tabular}{||l|l|l|l|l|l|l|l|l||}
\hline Sample \# & $\mathrm{pH}$ & $\mathrm{U}, \mathrm{ppm}$ & $\begin{array}{l}\mathrm{Cr}(\mathrm{VI}), \\
\mathrm{ppm}\end{array}$ & $\begin{array}{l}\Sigma \mathrm{Cr}, \\
\mathrm{ppm}\end{array}$ & $\begin{array}{l}\mathrm{NO}_{3 \prime}, \\
\mathrm{ppm}\end{array}$ & $\begin{array}{l}\mathrm{NO}_{2,} \\
\mathrm{ppm}\end{array}$ & $\begin{array}{l}\mathrm{Cl}_{,}, \\
\mathrm{ppm}\end{array}$ & $\begin{array}{l}\mathrm{SO}_{4 \prime} \\
\mathrm{ppm}\end{array}$ \\
\hline $3-0755-1$ & 7.40 & 5.7 & 29.7 & 26.8 & 65.6 & $<2.4$ & 39.2 & 496 \\
\hline $3-0755-2$ & 8.12 & $<0.00098$ & 0.22 & 0.29 & $<3.5$ & $<2.6$ & 0.46 & 53.4 \\
\hline $3-0755-3$ & 7.99 & $<0.00098$ & $<0.05$ & $<0.03$ & $<3.5$ & $<2.6$ & $<0.40$ & 23.0 \\
\hline $3-0755-4$ & 8.03 & 0.00029 & $<0.05$ & $<0.03$ & $<3.5$ & $<2.4$ & $<0.40$ & 18.5 \\
\hline
\end{tabular}


TEST \#13 (3-0756)

soil type: Fernald

moisture content: $14.45 \%$

contaminants: none

$\mathrm{H}_{2} \mathrm{~S}$ concentration: not treated

leachate: deionized water

\begin{tabular}{||l|l|l|l|l|l|l|l|l||}
\hline Sample \# & $\mathrm{pH}$ & $\mathrm{U}, \mathrm{ppm}$ & $\begin{array}{l}\mathrm{Cr}(\mathrm{VI}), \\
\mathrm{ppm}\end{array}$ & $\begin{array}{l}\Sigma \mathrm{Cr}, \\
\mathrm{ppm}\end{array}$ & $\begin{array}{l}\mathrm{NO}_{3,}, \\
\mathrm{ppm}\end{array}$ & $\begin{array}{l}\mathrm{NO}_{2,} \\
\mathrm{ppm}\end{array}$ & $\begin{array}{l}\mathrm{Cl}, \\
\mathrm{ppm}\end{array}$ & $\begin{array}{l}\mathrm{SO}_{4}, \\
\mathrm{ppm}\end{array}$ \\
\hline $3-0756-1$ & 7.67 & 0.0481 & $<0.05$ & 0.06 & 422 & $<2.4$ & 19.42 & 533 \\
\hline $3-0756-2$ & 7.62 & 0.00117 & $<0.05$ & 0.03 & $<3.5$ & $<2.4$ & 0.89 & 17.7 \\
\hline $3-0756-3$ & 7.67 & $<0.00098$ & $<0.05$ & $<0.03$ & $<3.5$ & $<2.4$ & $<0.40$ & $<3.5$ \\
\hline $3-0756-4$ & 7.71 & 0.00035 & $<0.05$ & $<0.03$ & $<3.5$ & $<2.4$ & $<0.40$ & $<3.5$ \\
\hline
\end{tabular}

TEST \#14 (3-0757)

soil type: Fernald

moisture content: $18.22 \%$

contaminants: none

$\mathrm{H}_{2} \mathrm{~S}$ concentration: $2000 \mathrm{ppm}$

leachate: deionized water

\begin{tabular}{||l|l|l|l|l|l|l|l|l||}
\hline \hline Sample \# & $\mathrm{pH}$ & $\mathrm{U}, \mathrm{ppm}$ & $\begin{array}{l}\mathrm{Cr}(\mathrm{VI}), \\
\mathrm{ppm}\end{array}$ & $\begin{array}{l}\Sigma \mathrm{Cr}, \\
\mathrm{ppm}\end{array}$ & $\begin{array}{l}\mathrm{NO}_{3 \prime}, \\
\mathrm{ppm}\end{array}$ & $\begin{array}{l}\mathrm{NO}_{2,}, \\
\mathrm{ppm}\end{array}$ & $\begin{array}{l}\mathrm{Cl}, \\
\mathrm{ppm}\end{array}$ & $\begin{array}{l}\mathrm{SO}_{4 \prime} \\
\mathrm{ppm}\end{array}$ \\
\hline $3-0757-1$ & 8.38 & 0.105 & $<0.05$ & 0.015 & $<2.9$ & $<2.5$ & 14.15 & 599 \\
\hline $3-0757-2$ & 8.15 & 0.0344 & - & $<0.013$ & $<2.9$ & $<2.5$ & 1.09 & 93.0 \\
\hline $3-0757-3$ & 7.93 & 0.00933 & $<0.05$ & $<0.013$ & $<2.9$ & $<2.5$ & 0.76 & 40.6 \\
\hline $3-0757-4$ & 7.85 & $<0.00588$ & $<0.05$ & 0.015 & $<2.9$ & $<2.5$ & 0.72 & 23.8 \\
\hline
\end{tabular}


TEST \#15 (3-0758)

soil type: Fernald

moisture content: $8.18 \%$

contaminants: $200 \mathrm{ppm} \mathrm{Cr}(\mathrm{VI}) / 200 \mathrm{ppm}$ U(VI)/100 ppm $\mathrm{NO}_{3}^{-}$

$\mathrm{H}_{2} \mathrm{~S}$ concentration: not treated

leachate: deionized water

\begin{tabular}{||l|l|l|l|l|l|l|l|l||}
\hline Sample \# & $\mathrm{pH}$ & $\mathrm{U}, \mathrm{ppm}$ & $\begin{array}{l}\mathrm{Cr}(\mathrm{Vl}), \\
\mathrm{ppm}\end{array}$ & $\begin{array}{l}\Sigma \mathrm{Cr}, \\
\mathrm{ppm}\end{array}$ & $\begin{array}{l}\mathrm{NO}_{3 \prime} \\
\mathrm{ppm}\end{array}$ & $\begin{array}{l}\mathrm{NO}_{2 \prime} \\
\mathrm{ppm}\end{array}$ & $\begin{array}{l}\mathrm{Cl}, \\
\mathrm{ppm}\end{array}$ & $\begin{array}{l}\mathrm{SO}_{4 \prime} \\
\mathrm{ppm}\end{array}$ \\
\hline $3-0758-1$ & 7.10 & 5.85 & 124.4 & 104.7 & 1002 & $<7.2$ & 26.05 & 477 \\
\hline $3-0758-2$ & 7.42 & 1.67 & 36.0 & 33.8 & $<3.5$ & $<2.4$ & 0.70 & 30.7 \\
\hline $3-0758-3$ & 7.13 & 0.80 & 8.32 & 8.6 & $<3.5$ & $<2.4$ & 0.49 & 6.7 \\
\hline $3-0758-4$ & 7.28 & 0.54 & 0.25 & 0.51 & $<3.5$ & $<2.4$ & $<0.40$ & 7.9 \\
\hline
\end{tabular}

TEST \#16 (3-0759)

soil type: Fernald

moisture content: $8.18 \%$

contaminants: $200 \mathrm{ppm} \mathrm{Cr}(\mathrm{VI}) / 200 \mathrm{ppm} \mathrm{U(VI)/100} \mathrm{ppm} \mathrm{NO}{ }^{-}$

$\mathrm{H}_{2} \mathrm{~S}$ concentration: $2000 \mathrm{ppm}$

leachate: deionized water

\begin{tabular}{||l|l|l|l|l|l|l|l|l||}
\hline Sample \# & $\mathrm{pH}$ & $\mathrm{U}, \mathrm{ppm}$ & $\begin{array}{l}\mathrm{Cr}(\mathrm{VI}), \\
\mathrm{ppm}\end{array}$ & $\begin{array}{l}\Sigma \mathrm{Cr}, \\
\mathrm{ppm}\end{array}$ & $\begin{array}{l}\mathrm{NO}_{3 \prime} \\
\mathrm{ppm}\end{array}$ & $\begin{array}{l}\mathrm{NO}_{2,} \\
\mathrm{ppm}\end{array}$ & $\begin{array}{l}\mathrm{Cl}_{,}, \\
\mathrm{ppm}\end{array}$ & $\begin{array}{l}\mathrm{SO}_{4}, \\
\mathrm{ppm}\end{array}$ \\
\hline $3-0759-1$ & 7.36 & 11.3 & $<0.05$ & 0.234 & 797 & 104 & 25.1 & 617 \\
\hline $3-0759-2$ & 7.27 & 8.97 & $<0.05$ & 0.112 & $<3.5$ & $<2.4$ & $<0.40$ & 82.6 \\
\hline $3-0759-3$ & 7.32 & 3.64 & $<0.05$ & 0.065 & $<3.5$ & $<2.4$ & $<0.40$ & 35.6 \\
\hline $3-0759-4$ & 7.53 & 1.66 & $<0.05$ & 0.092 & $<3.5$ & $<2.4$ & $<0.40$ & 14.6 \\
\hline
\end{tabular}


TEST \#17 (3-0760)

soil type: Fernald

moisture content: $6.95 \%$

contaminants: 200 ppm $\mathrm{Cr}(\mathrm{VI}) / 200 \mathrm{ppm} \mathrm{U}(\mathrm{VI}) / 100 \mathrm{ppm} \mathrm{NO}_{3}^{-}$

$\mathrm{H}_{2} \mathrm{~S}$ concentration: $100 \mathrm{ppm}$

leachate: deionized water

\begin{tabular}{||l|l|l|l|l|l|l|l|l||}
\hline \hline Sample \# & $\mathrm{pH}$ & $\mathrm{U}, \mathrm{ppm}$ & $\begin{array}{l}\mathrm{Cr}(\mathrm{VI}), \\
\mathrm{ppm}\end{array}$ & $\begin{array}{l}\mathrm{Cr}(\mathrm{T}), \\
\mathrm{ppm}\end{array}$ & $\begin{array}{l}\mathrm{NO}_{3,} \\
\mathrm{ppm}\end{array}$ & $\begin{array}{l}\mathrm{NO}_{2,} \\
\mathrm{ppm}\end{array}$ & $\begin{array}{l}\mathrm{Cl}, \\
\mathrm{ppm}\end{array}$ & $\begin{array}{l}\mathrm{SO}_{4}, \\
\mathrm{ppm}\end{array}$ \\
\hline $3-0760-1$ & 6.95 & 3.5 & 1.43 & 2.61 & 778 & 233 & 34.5 & 927 \\
\hline $3-0760-2$ & 7.22 & 1.88 & 0.197 & 0.68 & $<3.5$ & $<2.4$ & 0.65 & 115 \\
\hline $3-0760-3$ & 7.15 & 1.55 & $<0.05$ & 0.054 & $<3.5$ & $<2.4$ & $<0.40$ & 61.0 \\
\hline $3-0760-4$ & 7.41 & 0.77 & $<0.05$ & 0.067 & $<3.5$ & $<2.4$ & $<0.40$ & 20.7 \\
\hline
\end{tabular}

TEST \# 18 (3-0761)

soil type: Hanford (dry)

moisture content: $0.88 \%$

contaminants: 200 ppm $\mathrm{Cr}(\mathrm{VI}) / 200 \mathrm{ppm} \mathrm{U(VI)/100} \mathrm{ppm} \mathrm{NO}_{3}^{-}$

$\mathrm{H}_{2} \mathrm{~S}$ concentration: $2000 \mathrm{ppm}$

leachate: groundwater

\begin{tabular}{||l|l|l|l|l|l|l|l|l||}
\hline \hline Sample \# & $\mathrm{pH}$ & $\mathrm{U}, \mathrm{ppm}$ & $\begin{array}{l}\mathrm{Cr}(\mathrm{VI}), \\
\mathrm{ppm}\end{array}$ & $\begin{array}{l}\Sigma \mathrm{Cr}, \\
\mathrm{ppm}\end{array}$ & $\begin{array}{l}\mathrm{NO}_{3,} \\
\mathrm{ppm}\end{array}$ & $\begin{array}{l}\mathrm{NO}_{2,}, \\
\mathrm{ppm}\end{array}$ & $\begin{array}{l}\mathrm{Cl}, \\
\mathrm{ppm}\end{array}$ & $\begin{array}{l}\mathrm{SO}_{4 \prime}, \\
\mathrm{ppm}\end{array}$ \\
\hline $3-0761-1$ & 8.40 & 40.6 & 68.0 & 75.9 & 361 & $<2.4$ & 5.79 & 228 \\
\hline $3-0761-2$ & 8.42 & 56.3 & 2.46 & 1.70 & 5.48 & $<2.4$ & 3.04 & 26.1 \\
\hline $3-0761-3$ & 8.50 & 52.3 & 0.66 & 0.78 & $<3.5$ & $<2.4$ & 3.17 & 25.1 \\
\hline $3-0761-4$ & 8.24 & 44.0 & 0.34 & 0.38 & $<3.5$ & $<2.4$ & 3.26 & 37.5 \\
\hline
\end{tabular}


TEST \#19 (3-0762)

soil type: Hanford (moisture added)

moisture content: $9.70 \%$

contaminants: $200 \mathrm{ppm} \mathrm{Cr}(\mathrm{VI}) / 200 \mathrm{ppm} \mathrm{U}(\mathrm{VI}) / 100 \mathrm{ppm} \mathrm{NO}{ }_{3}^{-}$

$\mathrm{H}_{2} \mathrm{~S}$ concentration: $2000 \mathrm{ppm}$

leachate: groundwater

\begin{tabular}{||l|l|l|l|l|l|l|l|l||}
\hline Sample \# & $\mathrm{pH}$ & $\mathrm{U}, \mathrm{ppm}$ & $\begin{array}{l}\mathrm{Cr}(\mathrm{VI}), \\
\mathrm{ppm}\end{array}$ & $\begin{array}{l}\Sigma \mathrm{Cr}, \\
\mathrm{ppm}\end{array}$ & $\begin{array}{l}\mathrm{NO}_{3 \prime} \\
\mathrm{ppm}\end{array}$ & $\begin{array}{l}\mathrm{NO}_{2 \prime} \\
\mathrm{ppm}\end{array}$ & $\begin{array}{l}\mathrm{Cl}, \\
\mathrm{ppm}\end{array}$ & $\begin{array}{l}\mathrm{SO}_{4 \prime} \\
\mathrm{ppm}\end{array}$ \\
\hline $3-0762-1$ & 8.57 & 74.9 & 7.74 & 9.51 & 326 & $<2.4$ & 4.82 & 103 \\
\hline $3-0762-2$ & 8.47 & 50.6 & 0.114 & 0.163 & $<3.5$ & $<2.4$ & 3.35 & 24.7 \\
\hline $3-0762-3$ & 8.52 & 42.0 & $<0.05$ & 0.090 & $<3.5$ & $<2.4$ & 3.08 & 29.6 \\
\hline $3-0762-4$ & 8.27 & 34.8 & $<0.05$ & $<0.03$ & $<3.5$ & $<2.4$ & 3.26 & 41.8 \\
\hline
\end{tabular}

\section{DEIONIZED WATER AND GROUNDWATER ANALYSES}

\begin{tabular}{||l|l|l|l|l|l|l||}
\hline \hline Sample \# & $\mathrm{U}, \mathrm{ppm}$ & $\begin{array}{l}\Sigma \mathrm{Cr}, \\
\mathrm{ppm}\end{array}$ & $\begin{array}{l}\mathrm{NO}_{3 \prime} \\
\mathrm{ppm}\end{array}$ & $\begin{array}{l}\mathrm{NO}_{2,} \\
\mathrm{ppm}\end{array}$ & $\begin{array}{l}\mathrm{Cl}, \\
\mathrm{ppm}\end{array}$ & $\begin{array}{l}\mathrm{SO}_{4 \prime} \\
\mathrm{ppm}\end{array}$ \\
\hline $3-1008$ & $<0.00345$ & 0.043 & $<3.5$ & $<2.6$ & $<0.40$ & $<3.5$ \\
\hline $3-1009$ & $<0.00313$ & $<0.013$ & 4.57 & $<2.8$ & 2.82 & 19.3 \\
\hline $3-1077$ & 0.00400 & - & $<3.5$ & $<2.4$ & $<0.40$ & $<3.5$ \\
\hline $3-1078$ & $<0.00435$ & - & $<3.5$ & $<2.4$ & $<0.40$ & $<3.5$ \\
\hline
\end{tabular}

Samples 3-1008, 3-1077, and 3-1078 are deionized water.

Note: Average $\mathrm{pH}$ of deionized water $=5.91$ (ten measurements taken over the period 5/26/93-6/22/93, range 5.41-6.68).

Sample 3-1009 is the groundwater employed in the leach tests conducted with the soil from the Hanford Site. 
Concentrations of Cations and Metals of Selected Leachate Samples (ppm)

\begin{tabular}{||c|c|c|c|c|c|c|c|c|c|c|c|c|c|c|}
\hline Sample \# & Si & Al & $K$ & $\mathrm{Na}$ & $\mathrm{Ca}$ & $\mathrm{Mg}$ & $\mathrm{Cr}$ & $\mathrm{Fe}$ & $\mathrm{Pb}$ & $\mathrm{Cd}$ & $\mathrm{Mn}$ & $\mathrm{Ba}$ & $\mathrm{As}$ \\
\hline $3-0753-1$ & 4.49 & $<0.007$ & 24.1 & 201 & 163 & 32.6 & 315 & 0.032 & $<0.116$ & $<0.0095$ & $<0.002$ & 0.027 & 0.103 \\
\hline $3-0755-1$ & 10.04 & $<0.007$ & 18.5 & 178 & 188 & 36.7 & 26.8 & $<0.031$ & $<0.116$ & $<0.0095$ & 0.86 & 0.077 & $<0.016$ \\
\hline $3-0756-1$ & 7.53 & $<0.007$ & 58.1 & 15.3 & 273 & 69.0 & 0.064 & $<0.031$ & $<0.116$ & $<0.0095$ & $<0.002$ & 0.125 & $<0.016$ \\
\hline $3-0758-1$ & 6.61 & $<0.007$ & 58.0 & 209 & 359 & 88.0 & 104.7 & $<0.031$ & $<0.116$ & $<0.0095$ & 0.004 & 0.115 & $<0.016$ \\
\hline $3-0759-1$ & 5.40 & $<0.007$ & 47.8 & 224 & 410 & 102.2 & 0.234 & $<0.031$ & $<0.116$ & $<0.0095$ & 23.9 & 0.135 & $<0.016$ \\
\hline $3-0760-1$ & 8.76 & 0.256 & 49.8 & 263 & 648 & 158.5 & 2.61 & $<0.031$ & $<0.116$ & $<0.0095$ & 37.2 & 0.229 & $<0.016$ \\
\hline $3-0761-1$ & 12.54 & $<0.007$ & 16.9 & 197 & 169 & 21.1 & 75.9 & $<0.031$ & $<0.116$ & $<0.0095$ & 0.180 & 0.038 & $<0.016$ \\
\hline $3-0762-1$ & 10.68 & $<0.007$ & 18.1 & 179 & 106 & 11.8 & 9.51 & $<0.031$ & $<0.116$ & $<0.0095$ & 0.122 & 0.060 & $<0.016$ \\
\hline $3-1077$ & $<0.0085$ & 0.105 & 1.29 & 0.064 & $<0.054$ & 0.008 & $<0.030$ & $<0.031$ & $<0.116$ & $<0.0095$ & $<0.002$ & $<0.008$ & $<0.016$ \\
\hline $3-1078$ & $<0.0085$ & $<0.007$ & 0.231 & 0.756 & $<0.054$ & 0.005 & $<0.030$ & $<0.031$ & $<0.116$ & $<0.0095$ & $<0.002$ & $<0.008$ & $<0.016$ \\
\hline
\end{tabular}


WHC-EP-0694

A-12 
WHC-EP-0694

APPENDIX B ASSESSMENT OF CHROMIUM RECOVERY FROM TREATED SOILS 
WHC-EP-0694

B-ii 


\section{TEST \#1 (3-0744)}

In this test, a sample of uncontaminated soil from the Hanford Site was leached using groundwater from the Hanford unconfined aquifer. Hexavalent chromium was not detected in the leachate samples, but total chromium concentration values were obtained. The concentration of total leachable chromium for the soil sample was about $32 \mathrm{ppb}$.

Note: Leachate samples were weighed and converted to $\mathrm{mLs}$ based on assumption that $1 \mathrm{~mL}=1 \mathrm{gram}$. $\mathrm{Cr}(\mathrm{VI})$ refers to hexavalent chromium concentration of leachate samples as determined by spectrophotometric analysis while $\Sigma \mathrm{Cr}$ refers to total chromium concentration of leachate samples as determined by ICP analysis.

\begin{tabular}{|l|l|l|l|l|l||}
\hline \hline $\begin{array}{l}\text { \# COLUMN } \\
\text { PORE VOLUMES }\end{array}$ & $\begin{array}{l}\text { LEACHATE } \\
\text { VOLUME, } \mathrm{mLs}\end{array}$ & $\mathrm{CrNI}), \mathrm{mg} / \mathrm{L}$ & $\mathrm{Cr}(\mathrm{VI}), \mathrm{mg}$ & $\Sigma \mathrm{Cr}, \mathrm{mg} / \mathrm{L}$ & $\Sigma \mathrm{Cr}, \mathrm{mg}$ \\
\hline \hline $0.00-1.41$ & 146.55 & $<0.05$ & 0.00 & 0.025 & 0.0037 \\
\hline $1.41-2.52$ & 114.01 & - & 0.00 & 0.016 & 0.0018 \\
\hline $2.52-3.56$ & 108.66 & $<0.05$ & 0.00 & $<0.013$ & $<0.001$ \\
\hline $3.56-6.88$ & 342.88 & $<0.05$ & 0.00 & 0.021 & 0.0072 \\
\hline
\end{tabular}

Sample wt $=422.72 \mathrm{~g}$

Concentration of total leachable chromium in soil $=$

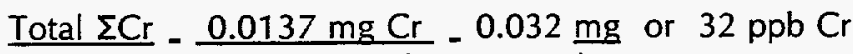
sample wt $\frac{0.0137 \mathrm{~g} \text {, soil }}{422.72 \mathrm{~kg}}$ 
TEST \#2 (3-0745)

In this test, a sample of uncontaminated soil from the Hanford Site was treated with $2000 \mathrm{ppm}$ $\mathrm{H}_{2} \mathrm{~S}$ and leached with groundwater from the Hanford unconfined aquifer. Both hexavalent chromium and total chromium concentrations were below detection limits.

Note: Leachate samples were weighed and converted to $\mathrm{mLs}$ based on assumption that $1 \mathrm{~mL}=1 \mathrm{gram}$. $\mathrm{Cr}(\mathrm{VI})$ refers to hexavalent chromium concentration of leachate samples as determined by spectrophotometric analysis while $\Sigma \mathrm{Cr}$ refers to total chromium concentration of leachate samples as determined by ICP analysis.

\begin{tabular}{||l|l|l|l|l|l||}
\hline $\begin{array}{l}\text { \# COLUMN } \\
\text { PORE VOLUMES }\end{array}$ & $\begin{array}{l}\text { LEACHATE } \\
\text { VOLUME, } \mathrm{mLs}\end{array}$ & $\mathrm{Cr}(\mathrm{NI}), \mathrm{mg} / \mathrm{L}$ & $\mathrm{CrNI}), \mathrm{mg}$ & $\Sigma \mathrm{Cr}, \mathrm{mg} / \mathrm{l}$ & $\Sigma \mathrm{Cr}, \mathrm{mg}$ \\
\hline \hline $0.00-1.71$ & 173.10 & $<0.05$ & 0.00 & $<0.013$ & 0.00 \\
\hline $1.71-3.03$ & 132.96 & $<0.05$ & 0.00 & $<0.013$ & 0.00 \\
\hline $3.03-4.30$ & 128.46 & $<0.05$ & 0.00 & $<0.013$ & 0.00 \\
\hline $4.30-8.33$ & 407.35 & $<0.05$ & 0.00 & $<0.013$ & 0.00 \\
\hline
\end{tabular}

Sample wt $=423.90 \mathrm{~g}$ 
IEST \#3 (3-0746)

In this test, a sample of soil from the Hanford Site was contaminated to $200 \mathrm{ppm}$ with $\mathrm{Cr}(\mathrm{VI})$ and leached with groundwater from the Hanford unconfined aquifer. A total of $51.24 \mathrm{mg}$ of $\mathrm{Cr}(\mathrm{VI})$ was leached from 427.91 grams of soil. This corresponds to $59.9 \%$ of the chromate present in the soil.

Note: Leachate samples were weighed and converted to $\mathrm{mLs}$ based on assumption that $1 \mathrm{~mL}=1 \mathrm{gram}$. $\mathrm{Cr}(\mathrm{VI})$ refers to hexavalent chromium concentration of leachate samples as determined by spectrophotometric analysis while $\Sigma \mathrm{Cr}$ refers to total chromium concentration of leachate samples as determined by ICP analysis.

\begin{tabular}{|c|c|c|c|c|c|}
\hline $\begin{array}{l}\text { \# COLUMN } \\
\text { PORE VOLUMES }\end{array}$ & $\begin{array}{l}\text { LEACHATE } \\
\text { VOLUME, } \mathrm{mLs}\end{array}$ & $\mathrm{Cr}(\mathrm{Vl}), \mathrm{mg} / \mathrm{L}$ & $\mathrm{Cr}(\mathrm{VI}), \mathrm{mg}$ & $\Sigma \mathrm{Cr}, \mathrm{mg} / \mathrm{L}$ & $\Sigma \mathrm{Cr}, \mathrm{mg}$ \\
\hline $0.00-1.81$ & 179.63 & 281.71 & 50.60 & 272.46 & 48.94 \\
\hline $1.81-3.00$ & 117.63 & 1.98 & 0.23 & 2.03 & 0.24 \\
\hline $3.00-4.24$ & 121.98 & 1.27 & 0.16 & 1.25 & 0.15 \\
\hline $4.24-7.75$ & 348.11 & 0.72 & 0.25 & 0.74 & 0.26 \\
\hline
\end{tabular}

Total $\mathrm{Cr}(\mathrm{Vl})=51.24 \mathrm{mg} \quad$ Total $\Sigma \mathrm{Cr}=49.59 \mathrm{mg}$

Total $\mathrm{Cr}(\mathrm{VI})$ present in soil $=$

$427.91 \mathrm{~g}$, soil $X \underline{0.200 \mathrm{mg} \mathrm{Cr}(V \mathrm{l})}=85.58 \mathrm{mg}, \mathrm{Cr}(\mathrm{VI})$

g, soil

$\% \mathrm{Cr}(\mathrm{VI})$ leached from soil $=$

$\frac{\text { Total } \mathrm{Cr}(\mathrm{VI}) \text { leached from soil }}{\text { Total } \mathrm{Cr}(\mathrm{VI}) \text { present in soil }} \times 100=\frac{51.24 \mathrm{mg}}{85.58 \mathrm{mg}} \times 100=59.9 \%$ 
TEST \#4 (3-0747)

In this test, a sample of Hanford Site soil was contaminated to $200 \mathrm{ppm}$ with $\mathrm{Cr}(\mathrm{VI})$, treated with $2000 \mathrm{ppm} \mathrm{H} \mathrm{H}_{2}$, and leached with groundwater from the Hanford Site unconfined aquifer. A total of 4.54 $\mathrm{mg}$ of $\mathrm{Cr}(\mathrm{VI})$ was leached from 423.37 grams of soil. This corresponds to $5.4 \%$ of the chromate present in the soil.

Note: Leachate samples were weighed and converted to $\mathrm{mLs}$ based on assumption that $1 \mathrm{~mL}=1 \mathrm{gram}$. $\mathrm{Cr}(\mathrm{VI})$ refers to hexavalent chromium concentration of leachate samples as determined by spectrophotometric analysis while $\Sigma \mathrm{Cr}$ refers to total chromium concentration of leachate samples as determined by ICP analysis.

\begin{tabular}{|l|l|l|l|l|l||}
\hline $\begin{array}{l}\text { \# COLUMN } \\
\text { PORE VOLUMES }\end{array}$ & $\begin{array}{l}\text { LEACHATE } \\
\text { VOLUME, } \mathrm{mLs}\end{array}$ & $\mathrm{Cr}(\mathrm{VI}), \mathrm{mg} / \mathrm{L}$ & $\mathrm{Cr}(\mathrm{VI}), \mathrm{mg}$ & $\Sigma \mathrm{Cr}, \mathrm{mg} / \mathrm{L}$ & $\Sigma \mathrm{Cr}, \mathrm{mg}$ \\
\hline \hline $0.00-1.35$ & 137.38 & 32.62 & 4.481 & 19.25 & 2.645 \\
\hline $1.35-2.37$ & 104.23 & 0.21 & 0.022 & 0.44 & 0.046 \\
\hline $2.37-3.43$ & 107.61 & 0.13 & 0.014 & 0.25 & 0.027 \\
\hline $3.43-6.49$ & 311.57 & 0.07 & 0.022 & 0.15 & 0.047 \\
\hline
\end{tabular}

Total $\mathrm{Cr}(\mathrm{VI})$ present in soil $=$

$423.37 \mathrm{~g}$, soil $\mathrm{X} \underline{0.200 \mathrm{mg} \operatorname{Cr}(\mathrm{VI})}=84.67 \mathrm{mg}, \mathrm{Cr}(\mathrm{VI})$

g, soil

$\% \mathrm{Cr}(\mathrm{VI})$ leached from soil $=$

Total $\mathrm{Cr}(\mathrm{VI})$ leached from soil $\times 100=\frac{4.54 \mathrm{mg}}{84.67 \mathrm{mg}} 100=5.4 \%$

Total $\mathrm{Cr}(\mathrm{VI})$ present in soil $\quad 84.67 \mathrm{mg}$ 
TEST \#5 (3-0748)

In this test, a sample of Hanford Site soil was contaminated to $200 \mathrm{ppm}$ with $\mathrm{Cr}(\mathrm{VI})$, treated with $100 \mathrm{ppm} \mathrm{H}_{2} \mathrm{~S}$, and leached with groundwater from the Hanford Site unconfined aquifer. A total of 1.29 $\mathrm{mg}$ of $\mathrm{Cr}(\mathrm{VI})$ was leached from $\mathbf{4 0 3 . 2 5}$ grams of soil. This corresponds to $1.6 \%$ of the chromate present in the soil.

Note: Leachate samples were weighed and converted to $\mathrm{mLs}$ based on assumption that $1 \mathrm{~mL}=1 \mathrm{gram}$. $\mathrm{Cr}(\mathrm{VI})$ refers to hexavalent chromium concentration of leachate samples as determined by spectrophotometric analysis while $\Sigma \mathrm{Cr}$ refers to total chromium concentration of leachate samples as determined by ICP analysis.

\begin{tabular}{|l|l|l|l|l|l||}
\hline \hline $\begin{array}{l}\text { \# COLUMN } \\
\text { PORE VOLUMES }\end{array}$ & $\begin{array}{l}\text { LEACHATE } \\
\text { VOLUME, } \mathrm{mLs}\end{array}$ & $\mathrm{Cr}(\mathrm{l}), \mathrm{mg} / \mathrm{L}$ & $\mathrm{Cr}(\mathrm{VI}), \mathrm{mg}$ & $\Sigma \mathrm{Cr}, \mathrm{mg} / \mathrm{L}$ & $\Sigma \mathrm{Cr}, \mathrm{mg}$ \\
\hline \hline $0.00-0.76$ & 78.46 & 15.73 & 1.234 & 15.66 & 1.229 \\
\hline $0.76-1.73$ & 99.98 & 0.34 & 0.034 & 0.47 & 0.047 \\
\hline $1.73-2.72$ & 102.39 & 0.12 & 0.012 & 0.13 & 0.013 \\
\hline $2.72-5.58$ & 294.77 & $<0.05$ & $<0.014$ & 0.095 & 0.028 \\
\hline
\end{tabular}

Total $\mathrm{Cr}(\mathrm{Vl})=1.29 \mathrm{mg} \quad$ Total $\Sigma \mathrm{Cr}=1.32 \mathrm{mg}$

Total $\mathrm{Cr}(\mathrm{VI})$ present in soil $=$

$403.25 \mathrm{~g}$, soil $X \underline{0.200 \mathrm{mg} \mathrm{Cr}(\mathrm{Vl})}=80.65 \mathrm{mg}, \mathrm{Cr}(\mathrm{Vl})$

$$
\text { g, soil }
$$

$\% \mathrm{Cr}(\mathrm{VI})$ leached from soil $=$

Total $\mathrm{Cr}(\mathrm{VI})$ leached from soil $\times 100=1.29 \mathrm{mg} \times 100=1.6 \%$

Total $\mathrm{Cr}(\mathrm{VI})$ present in soil $\quad 80.65 \mathrm{mg}$ 


\section{TEST \#6 (3-0749)}

In this test, a sample of Hanford Site soil was contaminated to $200 \mathrm{ppm}$ with $\mathrm{Cr}(\mathrm{VI})$ plus 5000 ppm $\mathrm{NO}_{3}^{-}$. It was then treated with $2000 \mathrm{ppm} \mathrm{H}_{2} \mathrm{~S}$ and leached with groundwater from the Hanford Site unconfined aquifer. A total of $3.39 \mathrm{mg}$ of $\mathrm{Cr}(\mathrm{VI})$ was leached from $423.28 \mathrm{grams}$ of soil. This corresponds to $4.0 \%$ of the chromate present in the soil.

Note: Leachate samples were weighed and converted to $\mathrm{mLs}$ based on assumption that $1 \mathrm{~mL}=1$ gram. $\mathrm{Cr}(\mathrm{VI})$ refers to hexavalent chromium concentration of leachate samples as determined by spectrophotometric analysis while $\Sigma \mathrm{Cr}$ refers to total chromium concentration of leachate samples as determined by ICP analysis.

\begin{tabular}{||l|l|l|l|l|l||}
\hline \hline $\begin{array}{l}\text { \# COLUMN } \\
\text { PORE VOLUMES }\end{array}$ & $\begin{array}{l}\text { LEACHATE } \\
\text { VOLUME, } \mathrm{mLs}\end{array}$ & Crrll), mg/L & CrVI), mg & $\Sigma \mathrm{Cr}, \mathrm{mg} / \mathrm{L}$ & $\Sigma \mathrm{Cr}, \mathrm{mg}$ \\
\hline \hline $0.00-1.47$ & 105.91 & 23.10 & 2.447 & 16.64 & 2.511 \\
\hline $1.47-2.54$ & 109.11 & 7.54 & 0.823 & 7.61 & 0.830 \\
\hline $2.54-3.63$ & 112.56 & 0.47 & 0.053 & 0.47 & 0.053 \\
\hline $3.63-6.79$ & 323.69 & 0.22 & 0.071 & 0.22 & 0.071 \\
\hline
\end{tabular}

Total $\mathrm{Cr}(\mathrm{VI})=3.39 \mathrm{mg}$

Total $\Sigma \mathrm{Cr}=3.47 \mathrm{mg}$

Total $\mathrm{Cr}(\mathrm{VI})$ present in soil $=$

$423.28 \mathrm{~g}$, soil X $\underline{0.200 \mathrm{mg} \mathrm{Cr}(\mathrm{VI})}=84.66 \mathrm{mg}, \mathrm{Cr}(\mathrm{VI})$

g, soil

$\% \mathrm{Cr}(\mathrm{VI})$ leached from soil $=$

Total $\mathrm{Cr}(\mathrm{VI})$ leached from soil $\times 100=\frac{3.39 \mathrm{mg} \times 100=4.0 \%}{84.66 \mathrm{mg}}$

Total $\mathrm{Cr}(\mathrm{VI})$ present in soil $\quad 84.66 \mathrm{mg}$ 
In this test, a sample of Hanford Site soil was contaminated to $200 \mathrm{ppm}$ with $\mathrm{Cr}(\mathrm{VI})$ plus 5000 $\mathrm{ppm} \mathrm{NO}_{3}^{-}$. It was then treated with $100 \mathrm{ppm} \mathrm{H}_{2} \mathrm{~S}$ and leached with groundwater from the Hanford Site unconfined aquifer. A total of $4.92 \mathrm{mg}$ of $\mathrm{Cr}(\mathrm{VI})$ was leached from 430.32 grams of soil. This corresponds to $5.7 \%$ of the chromate present in the soil.

Note: Leachate samples were weighed and converted to $\mathrm{mLs}$ based on assumption that $1 \mathrm{~mL}=1 \mathrm{gram}$. $\mathrm{Cr}(\mathrm{VI})$ refers to hexavalent chromium concentration of leachate samples as determined by spectrophotometric analysis while $\Sigma \mathrm{Cr}$ refers to total chromium concentration of leachate samples as determined by ICP analysis.

\begin{tabular}{|c|c|c|c|c|c|}
\hline $\begin{array}{l}\text { \# COLUMN } \\
\text { PORE VOLUMES }\end{array}$ & $\begin{array}{l}\text { LEACHATE } \\
\text { VOLUME, mLs }\end{array}$ & $\mathrm{Cr}(\mathrm{VI}), \mathrm{mg} / \mathrm{L}$ & $\mathrm{Cr}(\mathrm{VI}), \mathrm{mg}$ & $\Sigma \mathrm{Cr}, \mathrm{mg} / \mathrm{L}$ & $\Sigma \mathrm{Cr}, \mathrm{mg}$ \\
\hline $0.00-1.13$ & 108.66 & 29.95 & 3.254 & 25.81 & 2.805 \\
\hline $1.13-2.11$ & 94.89 & 13.86 & 1.315 & 14.05 & 1.333 \\
\hline $2.11-3.12$ & 97.20 & 2.89 & 0.281 & 2.95 & 0.287 \\
\hline $3.12-6.01$ & 278.01 & 0.25 & 0.070 & 0.34 & 0.095 \\
\hline
\end{tabular}

Total $\mathrm{Cr}(\mathrm{VI})$ present in soil $=$

$430.32 \mathrm{~g}$, soil $X \underline{0.200 \mathrm{mg} \operatorname{Cr}(\mathrm{Vl})}=86.06 \mathrm{mg}, \operatorname{Cr}(\mathrm{Vl})$

$$
\text { g, soil }
$$

$\% \operatorname{Cr}(\mathrm{VI})$ leached from soil $=$

$\frac{\text { Total } \mathrm{Cr}(\mathrm{VI}) \text { leached from soil }}{\text { Total } \mathrm{Cr}(\mathrm{VI}) \text { present in soil }} \times 100=\frac{4.92 \mathrm{mg}}{86.06 \mathrm{mg}} \times 100=5.7 \%$ 


\section{TEST \#8 (3-0751)}

In this test, a sample of uncontaminated Sandia soil was leached with deionized water. Both hexavalent and total chromium concentrations were below detection limits in the leachate samples.

Note: Leachate samples were weighed and converted to $\mathrm{mLs}$ based on assumption that $1 \mathrm{~mL}=1 \mathrm{gram}$. $\mathrm{Cr}(\mathrm{VI})$ refers to hexavalent chromium concentration of leachate samples as determined by spectrophotometric analysis while $\Sigma \mathrm{Cr}$ refers to total chromium concentration of leachate samples as determined by ICP analysis.

\begin{tabular}{||l|l|l|l|l|l||}
\hline $\begin{array}{l}\text { \# COLUMN } \\
\text { PORE VOLUMES }\end{array}$ & $\begin{array}{l}\text { LEACHATE } \\
\text { VOLUME, } \mathrm{mLs}\end{array}$ & Cr(VI), mg/L & CrNI), mg & $\Sigma \mathrm{Cr}, \mathrm{mg} / \mathrm{L}$ & $\Sigma \mathrm{Cr}, \mathrm{mg}$ \\
\hline \hline $0.00-1.18$ & 156.75 & $<0.05$ & 0.00 & $<0.013$ & 0.00 \\
\hline $1.18-2.13$ & 127.02 & $<0.05$ & 0.00 & $<0.013$ & 0.00 \\
\hline $2.13-3.05$ & 122.16 & $<0.05$ & 0.00 & $<0.013$ & 0.00 \\
\hline $3.05-5.97$ & 388.10 & $<0.05$ & 0.00 & $<0.013$ & 0.00 \\
\hline
\end{tabular}

Sample $w t=349.92 \mathrm{~g}$ 
TEST \#9 (3-0752)

In this test, a sample of uncontaminated Sandia soil was treated with $2000 \mathrm{ppm} \mathrm{H}_{2} \mathrm{~S}$ and leached with deionized water. Both hexavalent chromium and total chromium concentrations were below detection limits in the leachate samples.

Note: Leachate samples were weighed and converted to $\mathrm{mLs}$ based on assumption that $1 \mathrm{~mL}=1 \mathrm{gram}$. $\mathrm{Cr}(\mathrm{VI})$ refers to hexavalent chromium concentration of leachate samples as determined by spectrophotometric analysis while $\Sigma \mathrm{Cr}$ refers to total chromium concentration of leachate samples as determined by ICP analysis.

\begin{tabular}{||l|l|l|l|l|l||}
\hline \hline $\begin{array}{l}\text { \# COLUMN } \\
\text { PORE VOLUMES }\end{array}$ & $\begin{array}{l}\text { LEACHATE } \\
\text { VOLUME, } \mathrm{mLs}\end{array}$ & Cr(VI), $\mathrm{mg} / \mathrm{L}$ & $\mathrm{Cr}(\mathrm{VI}) \mathrm{mg}$ & $\Sigma \mathrm{Cr}, \mathrm{mg} / \mathrm{L}$ & $\Sigma \mathrm{Cr}, \mathrm{mg}$ \\
\hline \hline $0.00-1.12$ & 143.91 & $<0.05$ & 0.00 & $<0.013$ & 0.00 \\
\hline $1.12-2.18$ & 135.29 & $<0.05$ & 0.00 & $<0.013$ & 0.00 \\
\hline $2.18-3.20$ & 130.02 & $<0.05$ & 0.00 & $<0.013$ & 0.00 \\
\hline $3.20-6.43$ & 414.14 & $<0.05$ & 0.00 & $<0.013$ & 0.00 \\
\hline
\end{tabular}

Sample wt $=349.74 \mathrm{~g}$ 


\section{TEST \#10 (3-0753)}

In this test, a sample of Sandia soil was contaminated to $200 \mathrm{ppm}$ with $\mathrm{Cr}(\mathrm{VI})$ and leached with deionized water. A total of $45.73 \mathrm{mg}$ of $\mathrm{Cr}(\mathrm{VI})$ was leached from 376.15 grams of soil. This corresponds to $60.8 \%$ of the chromate present in the soil.

Note: Leachate samples were weighed and converted to $\mathrm{mLs}$ based on assumption that $1 \mathrm{~mL}=1 \mathrm{gram}$. $\mathrm{Cr}(\mathrm{VI})$ refers to hexavalent chromium concentration of leachate samples as determined by spectrophotometric analysis while $\Sigma \mathrm{Cr}$ refers to total chromium concentration of leachate samples as determined by ICP analysis.

\begin{tabular}{||l|l|l|l|l|l||}
\hline $\begin{array}{l}\text { \# COLUMN } \\
\text { PORE VOLUMES }\end{array}$ & $\begin{array}{l}\text { LEACHATE } \\
\text { VOLUME, } \mathrm{mLs}\end{array}$ & $\mathrm{Cr}(\mathrm{VII}, \mathrm{mg} / \mathrm{L}$ & $\mathrm{Cr}(\mathrm{ll}), \mathrm{mg}$ & $\Sigma \mathrm{Cr}, \mathrm{mg} / \mathrm{l}$ & $\Sigma \mathrm{Cr}, \mathrm{mg}$ \\
\hline \hline $0.00-1.14$ & 147.19 & 307.03 & 45.19 & 314.74 & 46.33 \\
\hline $1.14-2.10$ & 124.96 & 3.53 & 0.44 & 3.23 & 0.40 \\
\hline $2.10-3.08$ & 127.83 & 0.43 & 0.05 & 0.43 & 0.05 \\
\hline $3.08-6.06$ & 386.45 & 0.122 & 0.05 & 0.135 & 0.05 \\
\hline
\end{tabular}

Total $\mathrm{Cr}(\mathrm{VI})$ present in soil $=$

$376.15 \mathrm{~g}$, soil $X \underline{0.200 \mathrm{mg} \mathrm{Cr}(\mathrm{VI})}=75.23 \mathrm{mg}, \mathrm{Cr}(\mathrm{VI})$

g, soil

$\% \mathrm{Cr}(\mathrm{VI})$ leached from soil $=$

Total $\mathrm{Cr}(\mathrm{VI})$ leached from soil $\times 100=45.73 \mathrm{mg} \times 100=60.8 \%$

Total $\mathrm{Cr}(\mathrm{VI})$ present in soil $\quad 75.23 \mathrm{mg}$ 


\section{TEST \#11 (3-0754)}

In this test, a sample of Sandia soil was contaminated to $200 \mathrm{ppm}$ with $\mathrm{Cr}(\mathrm{VI})$. It was then treated with $2000 \mathrm{ppm} \mathrm{H}_{2} \mathrm{~S}$ and leached with deionized water. A total of $4.70 \mathrm{mg}$ of $\mathrm{Cr}(\mathrm{VI})$ was leached from 363.50 grams of soil. This corresponds to $6.5 \%$ of the chromate present in the soil.

Note: Leachate samples were weighed and converted to $\mathrm{mLs}$ based on assumption that $1 \mathrm{~mL}=1$ gram. $\mathrm{Cr}(\mathrm{VI})$ refers to hexavalent chromium concentration of leachate samples as determined by spectrophotometric analysis while $\Sigma \mathrm{Cr}$ refers to total chromium concentration of leachate samples as determined by ICP analysis.

\begin{tabular}{||l|l|l|l|l|l||}
\hline $\begin{array}{l}\text { \# COLUMN } \\
\text { PORE VOLUMES }\end{array}$ & $\begin{array}{l}\text { LEACHATE } \\
\text { VOLUME, mLs }\end{array}$ & $\mathrm{Cr}(\mathrm{NI}), \mathrm{mg} / \mathrm{L}$ & $\mathrm{Cr}(\mathrm{NI}), \mathrm{mg}$ & $\Sigma \mathrm{Cr}, \mathrm{mg} / \mathrm{L}$ & $\Sigma \mathrm{Cr}, \mathrm{mg}$ \\
\hline \hline $0.00-0.99$ & 130.26 & 32.86 & 4.280 & - & - \\
\hline $0.99-2.15$ & 151.75 & 2.54 & 0.385 & 2.35 & 0.357 \\
\hline $2.15-3.34$ & 155.82 & $<0.05$ & $<0.008$ & $<0.03$ & $<0.005$ \\
\hline $3.34-6.99$ & 479.67 & $<0.05$ & $<0.024$ & $<0.03$ & $<0.014$ \\
\hline
\end{tabular}

Total $\mathrm{Cr}(\mathrm{VI})=4.70 \mathrm{mg}$

Total $\mathrm{Cr}(\mathrm{VI})$ present in soil $=$

$363.50 \mathrm{~g}$, soil X $\underline{0.200 \mathrm{mg} \operatorname{Cr}(\mathrm{VI})}=72.70 \mathrm{mg}, \mathrm{Cr}(\mathrm{VI})$

g, soil

$\% \mathrm{Cr}(\mathrm{VI})$ leached from soil $=$

$\frac{\text { Total } \operatorname{Cr}(\mathrm{V} \mid) \text { leached from soil }}{\text { Total } \operatorname{Cr}(\mathrm{V} \mid) \text { present in soil }} \times 100=\frac{4.70 \mathrm{mg}}{72.70 \mathrm{mg}} \times 100=6.5 \%$ 
TEST \#12 (3-0755)

In this test, a sample of Sandia soil was contaminated to $200 \mathrm{ppm}$ with $\mathrm{Cr}(\mathrm{VI})$. It was then treated with $100 \mathrm{ppm} \mathrm{H}_{2} \mathrm{~S}$ and leached with deionized water. A total of $3.47 \mathrm{mg}$ of $\mathrm{Cr}(\mathrm{VI})$ was leached from 362.49 grams of soil. This corresponds to $4.8 \%$ of the chromate present in the soil.

Note: Leachate samples were weighed and converted to $\mathrm{mLs}$ based on assumption that $1 \mathrm{~mL}=1 \mathrm{gram}$. $\mathrm{Cr}(\mathrm{VI})$ refers to hexavalent chromium concentration of leachate samples as determined by spectrophotometric analysis while $\Sigma \mathrm{Cr}$ refers to total chromium concentration of leachate samples as determined by ICP analysis.

\begin{tabular}{||l|l|l|l|l|l||}
\hline \hline $\begin{array}{l}\text { \# COLUMN } \\
\text { PORE VOLUMES }\end{array}$ & $\begin{array}{l}\text { LEACHATE } \\
\text { VOLUME, } \mathrm{mLs}\end{array}$ & $\mathrm{Cr}(\mathrm{VI}), \mathrm{mg} / \mathrm{L}$ & $\mathrm{Cr}(\mathrm{NI}), \mathrm{mg}$ & $\Sigma \mathrm{Cr}, \mathrm{mg} / \mathrm{L}$ & $\Sigma \mathrm{Cr}, \mathrm{mg}$ \\
\hline \hline $0.00-0.87$ & 114.78 & 29.69 & 3.408 & 26.77 & 3.073 \\
\hline $0.87-1.89$ & 134.92 & 0.22 & 0.030 & 0.29 & 0.039 \\
\hline $1.89-2.93$ & 136.98 & $<0.05$ & $<0.007$ & $<0.03$ & $<0.004$ \\
\hline $2.93-6.10$ & 417.46 & $<0.05$ & $<0.021$ & $<0.03$ & $<0.013$ \\
\hline
\end{tabular}

Total $\mathrm{Cr}(\mathrm{VI})$ present in soil $=$

$362.49 \mathrm{~g}$, soil $\mathrm{X} \underline{0.200 \mathrm{mg} \mathrm{Cr}(\mathrm{VI})}=72.50 \mathrm{mg}, \mathrm{Cr}(\mathrm{VI})$

g, soil

$\% \operatorname{Cr}(\mathrm{VI})$ leached from soil $=$

Total $\mathrm{Cr}(\mathrm{VI})$ leached from soil $\times 100=3.47 \mathrm{mg} \times 100=4.8 \%$

Total $\mathrm{Cr}(\mathrm{VI})$ present in soil $\quad 72.50 \mathrm{mg}$ 
TEST \#13 (3-0756)

In this test, a sample of uncontaminated Fernald soil was leached with deionized water.

Hexavalent chromium was not detected in any leachate samples, but total chromium concentration values were reported for the first two samples. The concentration of total leachable chromium in the soil sample was approximately $27 \mathrm{ppb}$.

Note: Leachate samples were weighed and converted to $\mathrm{mLs}$ based on assumption that $1 \mathrm{~mL}=1$ gram. $\mathrm{Cr}(\mathrm{VI})$ refers to hexavalent chromium concentration of leachate samples as determined by spectrophotometric analysis while $\Sigma \mathrm{Cr}$ refers to total chromium concentration of leachate samples as determined by ICP analysis.

\begin{tabular}{||l|l|l|l|l|l||}
\hline $\begin{array}{l}\text { \# COLUMN } \\
\text { PORE VOLUMES }\end{array}$ & $\begin{array}{l}\text { LEACHATE } \\
\text { VOLUME, } \mathrm{mLs}\end{array}$ & $\mathrm{Cr}(\mathrm{VI}), \mathrm{mg} / \mathrm{L}$ & $\mathrm{Cr}(\mathrm{VI}), \mathrm{mg}$ & $\Sigma \mathrm{Cr}, \mathrm{mg} / \mathrm{L}$ & $\Sigma \mathrm{Cr}, \mathrm{mg}$ \\
\hline \hline $0.00-0.98$ & 153.30 & $<0.05$ & 0.00 & 0.064 & 0.0085 \\
\hline $0.98-2.02$ & 142.16 & $<0.05$ & 0.00 & $<0.030$ & 0.00 \\
\hline $2.02-3.09$ & 145.09 & $<0.05$ & 0.00 & $<0.030$ & 0.00 \\
\hline $3.09-6.36$ & 445.35 & $<0.05$ & 0.00 & $<0.030$ & 0.00 \\
\hline
\end{tabular}

Sample wt $=324.16 \mathrm{~g}$

Concentration of total leachable chromium in soil = $\frac{\text { Total } \Sigma \mathrm{Cr}}{\text { sample wt }}-\frac{0.009 \mathrm{mg} \mathrm{Cr}}{324.16 \mathrm{~g} \text {, soil }}-0.027 \frac{\mathrm{mg}}{\mathrm{kg}}$ or $27 \mathrm{ppb} \mathrm{Cr}$ 
TEST \#14 (3-0757)

In this test, a sample of uncontaminated Fernald soil was treated with $2000 \mathrm{ppm} \mathrm{H}_{2} \mathrm{~S}$ and leached with deionized water. Both hexavalent chromium and total chromium concentrations were at or below detection limits in the leachate samples. The concentration of total leachable chromium in the soil sample was about $33 \mathrm{ppb}$.

Note: Leachate samples were weighed and converted to $\mathrm{mLs}$ based on assumption that $1 \mathrm{~mL}-1$ gram. $\mathrm{Cr}(\mathrm{VI})$ refers to hexavalent chromium concentration of leachate samples as determined by spectrophotometric analysis while $\mathbf{\Sigma C r}$ refers to total chromium concentration of leachate samples as determined by ICP analysis.

\begin{tabular}{||l|l|l|l|l|l||}
\hline $\begin{array}{l}\text { \# COLUMN } \\
\text { PORE VOLUMES }\end{array}$ & $\begin{array}{l}\text { LEACHATE } \\
\text { VOLUME, } \mathrm{mLs}\end{array}$ & $\mathrm{Cr}(\mathrm{NI}), \mathrm{mg} / \mathrm{L}$ & $\mathrm{Cr}(\mathrm{VI}), \mathrm{mg}$ & $\Sigma \mathrm{Cr}, \mathrm{mg} / \mathrm{l}$ & $\Sigma \mathrm{Cr}, \mathrm{mg}$ \\
\hline \hline $0.00-1.07$ & 150.09 & $<0.05$ & 0.00 & 0.015 & 0.0023 \\
\hline $1.07-1.97$ & 125.57 & - & - & $<0.013$ & $<0.0016$ \\
\hline $1.97-2.83$ & 120.62 & $<0.05$ & 0.00 & $<0.013$ & $<0.0016$ \\
\hline $2.83-5.57$ & 383.09 & $<0.05$ & 0.00 & 0.015 & 0.0057 \\
\hline
\end{tabular}

Sample wt $=329.47 \mathrm{~g}$

Concentration of total leachable chromium in soil $=$

Total $\Sigma \mathrm{Cr}-\frac{0.011 \mathrm{mg} \mathrm{Cr}}{329.47 \mathrm{gr} \mathrm{sol}}-0.033 \mathrm{mg}$ or $33 \mathrm{ppb} \mathrm{Cr}$ sample wt $329.47 \mathrm{~g}$, soil $\mathrm{kg}$ 


\section{TEST \#15 (3-0758)}

In this test, a sample of Fernald soil was contaminated to $200 \mathrm{ppm}$ with $\mathrm{Cr}(\mathrm{VI})$ and leached with deionized water. A total of $16.61 \mathrm{mg}$ of $\mathrm{Cr}(\mathrm{VI})$ was leached from 320.95 grams of soil. This corresponds to $25.9 \%$ of the chromate present in the soil.

Note: Leachate samples were weighed and converted to $\mathrm{mLs}$ based on assumption that $1 \mathrm{~mL}=1$ gram. $\mathrm{Cr}(\mathrm{VI})$ refers to hexavalent chromium concentration of leachate samples as determined by spectrophotometric analysis while $\Sigma \mathrm{Cr}$ refers to total chromium concentration of leachate samples as determined by ICP analysis.

\begin{tabular}{||l|l|l|l|l|l||}
\hline $\begin{array}{l}\text { \# COLUMN } \\
\text { PORE VOLUMES }\end{array}$ & $\begin{array}{l}\text { LEACHATE } \\
\text { VOLUME, } \mathrm{mLs}\end{array}$ & $\mathrm{Cr}(\mathrm{NI}) \mathrm{mg} / \mathrm{L}$ & $\mathrm{Cr}(\mathrm{VII}) \mathrm{mg}$ & $\Sigma \mathrm{Cr}, \mathrm{mg} / \mathrm{L}$ & $\Sigma \mathrm{Cr}, \mathrm{mg}$ \\
\hline \hline $0.00-0.66$ & 90.02 & 124.36 & 11.19 & 104.7 & 9.43 \\
\hline $0.66-1.55$ & 120.09 & 36.03 & 4.33 & 33.8 & 4.06 \\
\hline $1.55-2.45$ & 121.58 & 8.32 & 1.01 & 8.6 & 1.05 \\
\hline $2.45-4.96$ & 340.48 & 0.25 & 0.08 & 0.51 & 0.17 \\
\hline
\end{tabular}

Total $\mathrm{Cr}(\mathrm{VI})$ present in soil $=$

$320.95 \mathrm{~g}$, soil $X \underline{0.200 \mathrm{mg} \mathrm{Cr}(\mathrm{Vl})}=64.19 \mathrm{mg}, \mathrm{Cr}(\mathrm{VI})$

g, soil

$\% \mathrm{Cr}(\mathrm{VI})$ leached from soil $=$

Total $\mathrm{Cr}(\mathrm{VI})$ leached from soil $\times 100=\frac{16.61 \mathrm{mg}}{64.19 \mathrm{mg}} \times 100=25.9 \%$

Total $\mathrm{Cr}(\mathrm{VI})$ present in soil $\quad 64.19 \mathrm{mg}$ 
TEST \#16 (3-0759)

In this test, a sample of Fernald soil was contaminated to $200 \mathrm{ppm}$ with $\mathrm{Cr}(\mathrm{VI})$. It was then treated with $2000 \mathrm{ppm} \mathrm{H} \mathrm{H}_{2} \mathrm{~S}$ and leached with deionized water. Hexavalent chromium was below the detection limit in all leachate samples.

Note: Leachate samples were weighed and converted to $\mathrm{mLs}$ based on assumption that $1 \mathrm{~mL}=1$ gram. $\mathrm{Cr}(\mathrm{VI})$ refers to hexavalent chromium concentration of leachate samples as determined by spectrophotometric analysis while $\Sigma \mathrm{Cr}$ refers to total chromium concentration of leachate samples as determined by ICP analysis.

\begin{tabular}{||l|l|l|l|l|l||}
\hline $\begin{array}{l}\text { \# COLUMN } \\
\text { PORE VOLUMES }\end{array}$ & $\begin{array}{l}\text { LEACHATE } \\
\text { VOLUME, } \mathrm{mLs}\end{array}$ & $\mathrm{Cr}(\mathrm{NI}), \mathrm{mg} / \mathrm{L}$ & $\mathrm{Cr}(\mathrm{NI}), \mathrm{mg}$ & $\Sigma \mathrm{Cr}, \mathrm{mg} / \mathrm{L}$ & $\Sigma \mathrm{Cr}, \mathrm{mg}$ \\
\hline \hline $0.00-0.69$ & 93.73 & $<0.05$ & $<0.0047$ & 0.234 & 0.0219 \\
\hline $0.69-1.59$ & 122.35 & $<0.05$ & $<0.0061$ & 0.112 & 0.0137 \\
\hline $1.59-2.51$ & 124.60 & $<0.05$ & $<0.0062$ & 0.065 & 0.0081 \\
\hline $2.51-5.08$ & 349.57 & $<0.05$ & $<0.0175$ & 0.092 & 0.0322 \\
\hline
\end{tabular}

$$
\text { Total } \mathrm{Cr}(\mathrm{VI})=<0.0345 \mathrm{mg} \quad \text { Total } \Sigma \mathrm{Cr}=0.0759 \mathrm{mg}
$$

Total $\mathrm{Cr}(\mathrm{VI})$ present in soil $=$

$323.93 \mathrm{~g}$, soil $\times \underline{0.200 \mathrm{mg} \mathrm{Cr}(\mathrm{VI})}=64.79 \mathrm{mg}, \mathrm{Cr}(\mathrm{Vl})$

g, soil

$\% \mathrm{Cr}(\mathrm{Vl})$ leached from soil $=$

Total $\mathrm{Cr}(\mathrm{VI})$ leached from soil $\times 100=\leq 0.0345 \mathrm{mg} \times 100=<0.05 \%$

Total $\mathrm{Cr}(\mathrm{VI})$ present in soil $\quad 64.79 \mathrm{mg}$ 
TEST \#17 (3-0760)

In this test, a sample of Fernald soil was contaminated to $200 \mathrm{ppm}$ with $\mathrm{Cr}(\mathrm{VI})$. It was then treated with $100 \mathrm{ppm} \mathrm{H}_{2} \mathrm{~S}$ and leached with deionized water. A total of about $0.16 \mathrm{mg}$ of $\mathrm{Cr}(\mathrm{VI})$ was leached from 320.80 grams of soil. This corresponds to $0.25 \%$ of the chromate present in the soil.

Note: Leachate samples were weighed and converted to $\mathrm{mLs}$ based on assumption that $1 \mathrm{~mL}=1 \mathrm{gram}$. $\mathrm{Cr}(\mathrm{Vl})$ refers to hexavalent chromium concentration of leachate samples as determined by spectrophotometric analysis while $\Sigma \mathrm{Cr}$ refers to total chromium concentration of leachate samples as determined by ICP analysis.

\begin{tabular}{||l|l|l|l|l|l||}
\hline \hline $\begin{array}{l}\text { \# COLUMN } \\
\text { PORE VOLUMES }\end{array}$ & $\begin{array}{l}\text { LEACHATE } \\
\text { VOLUME, } \mathrm{mLs}\end{array}$ & $\mathrm{Cr}(\mathrm{Ml}), \mathrm{mg} / \mathrm{L}$ & $\mathrm{Cr}(\mathrm{VI}), \mathrm{mg}$ & $\Sigma \mathrm{Cr}, \mathrm{mg} / \mathrm{L}$ & $\Sigma \mathrm{Cr}, \mathrm{mg}$ \\
\hline \hline $0.00-0.60$ & 79.19 & 1.43 & 0.113 & 2.61 & 0.207 \\
\hline $0.60-1.55$ & 124.69 & 0.197 & 0.025 & 0.68 & 0.085 \\
\hline $1.55-2.52$ & 127.32 & $<0.05$ & $<0.006$ & 0.054 & 0.007 \\
\hline $2.52-5.23$ & 356.44 & $<0.05$ & $<0.018$ & 0.067 & 0.024 \\
\hline
\end{tabular}

Total $\mathrm{Cr}(\mathrm{VI})$ present in soil $=$

$320.80 \mathrm{~g}$, soil $\mathrm{X} \underline{0.200 \mathrm{mg} \mathrm{Cr}(\mathrm{VI})}=64.16 \mathrm{mg}, \mathrm{Cr}(\mathrm{Vl})$

$\mathrm{g}$, soil

$\% \mathrm{Cr}(\mathrm{VI})$ leached from soil $=$

Total $\mathrm{Cr}(\mathrm{VI})$ leached from soil $\times 100=0.16 \mathrm{mg} \times 100=0.25 \%$

Total $\mathrm{Cr}(\mathrm{VI})$ present in soil $\quad 64.16 \mathrm{mg}$ 


\section{TEST \#18 (3-0761)}

In this test, a sample of Hanford Site soil was contaminated to $200 \mathrm{ppm}$ with $\mathrm{Cr}(\mathrm{VI})$ and air dryed to a moisture content of $0.88 \%$. The soil was then treated with $2000 \mathrm{ppm} \mathrm{H}_{2} \mathrm{~S}$, and leached with groundwater from the Hanford Site unconfined aquifer. A total of $9.55 \mathrm{mg}$ of $\mathrm{Cr}(\mathrm{VI})$ was leached from 422.40 grams of soil. This corresponds to $11.3 \%$ of the chromate present in the soil.

Note: Leachate samples were weighed and converted to $\mathrm{mLs}$ based on assumption that $1 \mathrm{~mL}=1 \mathrm{gram}$. $\mathrm{Cr}(\mathrm{VI})$ refers to hexavalent chromium concentration of leachate samples as determined by spectrophotometric analysis while $\Sigma \mathrm{Cr}$ refers to total chromium concentration of leachate samples as determined by ICP analysis.

\begin{tabular}{||l|l|l|l|l|l||}
\hline $\begin{array}{l}\text { \# COLUMN } \\
\text { PORE VOLUMES }\end{array}$ & $\begin{array}{l}\text { LEACHATE } \\
\text { VOLUME, } \mathrm{mLs}\end{array}$ & $\mathrm{Cr}(\mathrm{NI}), \mathrm{mg} / \mathrm{L}$ & $\mathrm{Cr}(\mathrm{NI}), \mathrm{mg}$ & $\Sigma \mathrm{Cr}, \mathrm{mg} / \mathrm{L}$ & $\Sigma \mathrm{Cr}, \mathrm{mg}$ \\
\hline \hline $0.00-1.38$ & 132.33 & 67.97 & 8.99 & 75.92 & 10.05 \\
\hline $1.38-2.79$ & 136.32 & 2.46 & 0.34 & 1.70 & 0.23 \\
\hline $2.79-4.24$ & 138.97 & 0.66 & 0.09 & 0.78 & 0.11 \\
\hline $4.24-8.29$ & 389.14 & 0.34 & 0.13 & 0.38 & 0.15 \\
\hline
\end{tabular}

Total $\mathrm{Cr}(\mathrm{V} l)$ present in soil $=$

$422.40 \mathrm{~g}$, soil $X \underline{0.200 \mathrm{mg} \operatorname{Cr}(V I)}=84.48 \mathrm{mg}, \mathrm{Cr}(\mathrm{Vl})$

g, soil

$\% \operatorname{Cr}(\mathrm{VI})$ leached from soil $=$

$\frac{\text { Total } \mathrm{Cr}(\mathrm{VI}) \text { leached from soil }}{\text { Total } \mathrm{Cr}(\mathrm{VI}) \text { present in soil }} \times 100=\frac{9.55 \mathrm{mg}}{84.48 \mathrm{mg}} \times 100=11.3 \%$ 
TEST \#19 (3-0762)

In this test, a sample of Hanford Site soil was contaminated to $200 \mathrm{ppm}$ with $\mathrm{Cr}(\mathrm{VI})$ and additional water added to attain a moisture content of $9.70 \%$. The soil was then treated with $2000 \mathrm{ppm} \mathrm{H}_{2} \mathrm{~S}$, and leached with groundwater from the Hanford Site unconfined aquifer. A total of $1.27 \mathrm{mg}$ of $\mathrm{Cr}(\mathrm{VI})$ was leached from 457.50 grams of soil. This corresponds to $1.4 \%$ of the chromate present in the soil.

Note: Leachate samples were weighed and converted to $\mathrm{mLs}$ based on assumption that $1 \mathrm{~mL}=1$ gram. $\mathrm{Cr}(\mathrm{V})$ refers to hexavalent chromium concentration of leachate samples as determined by spectrophotometric analysis while $\Sigma \mathrm{Cr}$ refers to total chromium concentration of leachate samples as determined by ICP analysis.

\begin{tabular}{||l|l|l|l|l|l||}
\hline $\begin{array}{l}\text { \# COLUMN } \\
\text { PORE VOLUMES }\end{array}$ & $\begin{array}{l}\text { LEACHATE } \\
\text { VOLUME, } \mathrm{mLs}\end{array}$ & $\mathrm{Cr}(\mathrm{VII}, \mathrm{mg} / \mathrm{L}$ & $\mathrm{Cr}(\mathrm{II}), \mathrm{mg}$ & $\Sigma \mathrm{Cr}, \mathrm{mg} / \mathrm{L}$ & $\Sigma \mathrm{Cr}, \mathrm{mg}$ \\
\hline \hline $0.00-1.71$ & 158.40 & 7.74 & 1.226 & 9.51 & 1.506 \\
\hline $1.71-3.12$ & 130.92 & 0.114 & 0.015 & 0.163 & 0.021 \\
\hline $3.12-4.55$ & 133.44 & $<0.05$ & $<0.007$ & 0.090 & 0.012 \\
\hline $4.55-8.57$ & 372.97 & $<0.05$ & $<0.019$ & $<0.030$ & $<0.011$ \\
\hline
\end{tabular}

Total $\mathrm{Cr}(\mathrm{VI})=1.27 \mathrm{mg}$

Total $\Sigma \mathrm{Cr}=1.55 \mathrm{mg}$

Total $\mathrm{Cr}(\mathrm{VI})$ present in soil $=$

$457.50 \mathrm{~g}$, soil $\times \underline{0.200 \mathrm{mg} \operatorname{Cr}(\mathrm{VI})}=91.50 \mathrm{mg}, \operatorname{Cr}(\mathrm{VI})$

g, soil

$\% \mathrm{Cr}(\mathrm{VI})$ leached from soil $=$

$\frac{\text { Total } \operatorname{Cr}(\mathrm{V} \mid) \text { leached from soil }}{\text { Total } \operatorname{Cr}(\mathrm{V}) \text { present in soil }} \times 100=\frac{1.27 \mathrm{mg}}{91.50 \mathrm{mg}} \times 100=1.4 \%$ 
WHC-EP-0694

B-20 
WHC-EP-0694

APPENDIX C

ASSESSMENT OF URANIUM RECOVERY FROM TREATED SOILS 
WHC-EP-0694

C-ii 


\section{TEST \#1 (3-0744)}

In this test, a sample of uncontaminated soil from the Hanford Site was leached using groundwater from the Hanford unconfined aquifer. Uranium was not detected in the leachate samples.

Note: Leachate samples were weighed and converted to $\mathrm{mLs}$ based on assumption that $1 \mathrm{~mL}=1$ gram.

\begin{tabular}{||l|l|l|l||}
\hline $\begin{array}{l}\text { \# COLUMN } \\
\text { PORE VOLUMES }\end{array}$ & $\begin{array}{l}\text { LEACHATE } \\
\text { VOLUME, } \mathrm{mLs}\end{array}$ & $\mathrm{U}, \mathrm{mg} / \mathrm{L}$ & $\mathrm{U}, \mathrm{mg}$ \\
\hline \hline $0.00-1.41$ & 146.55 & $<0.00526$ & 0.00 \\
\hline $1.41-2.52$ & 114.01 & $<0.00385$ & 0.00 \\
\hline $2.52-3.56$ & 108.66 & $<0.00485$ & 0.00 \\
\hline $3.56-6.88$ & 342.88 & $<0.00400$ & 0.00 \\
\hline
\end{tabular}

Sample $w t=422.72 \mathrm{~g}$ 
TEST \#2 (3-0745)

In this test, a sample of uncontaminated soil from the Hanford Site was treated with $2000 \mathrm{ppm}$ $\mathrm{H}_{2} \mathrm{~S}$ and leached with groundwater from the Hanford unconfined aquifer. Uranium concentrations were at or below detection limits.

Note: Leachate samples were weighed and converted to $\mathrm{mLs}$ based on assumption that $1 \mathrm{~mL}=1$ gram.

\begin{tabular}{|l|l|l|l|}
\hline $\begin{array}{l}\text { \# COLUMN } \\
\text { PORE VOLUMES }\end{array}$ & $\begin{array}{l}\text { LEACHATE } \\
\text { VOLUME, } \mathrm{m} \ell \mathrm{s}\end{array}$ & $\mathrm{U}, \mathrm{mg} / \mathrm{L}$ & $\mathrm{U}, \mathrm{mg}$ \\
\hline \hline $0.00-1.71$ & 173.10 & $<0.00500$ & 0.00 \\
\hline $1.71-3.03$ & 132.96 & $<0.00385$ & 0.00 \\
\hline $3.03-4.30$ & 128.46 & $<0.00400$ & 0.00 \\
\hline $4.30-8.33$ & 407.35 & 0.00333 & 0.0014 \\
\hline
\end{tabular}

Sample wt $=423.90 \mathrm{~g}$ 
In this test, a sample of soil from the Hanford Site was contaminated to $200 \mathrm{ppm}$ with U(VI) and leached with groundwater from the Hanford unconfined aquifer. A total of $59.46 \mathrm{mg}$ of uranium was leached from 427.91 grams of soil. This corresponds to $69.5 \%$ of the uranium added to the soil.

Note: Leachate samples were weighed and converted to $\mathrm{mLs}$ based on assumption that $1 \mathrm{~mL}=1$ gram.

\begin{tabular}{|l|l|l|l||}
\hline $\begin{array}{l}\text { \# COLUMN } \\
\text { PORE VOLUMES }\end{array}$ & $\begin{array}{l}\text { LEACHATE } \\
\text { VOLUME, } \mathrm{mLs}\end{array}$ & $\mathrm{U}, \mathrm{mg} / \mathrm{L}$ & $\mathrm{U}, \mathrm{mg}$ \\
\hline \hline $0.00-1.81$ & 179.63 & 216 & 38.80 \\
\hline $1.81-3.00$ & 117.63 & 56.0 & 6.59 \\
\hline $3.00-4.24$ & 121.98 & 42.9 & 5.23 \\
\hline $4.24-7.75$ & 348.11 & 25.4 & 8.84 \\
\hline \multicolumn{4}{|r|}{ Total $U=59.46 \mathrm{mg}$} \\
\hline
\end{tabular}

Total U(VI) added to soil $=$

$427.91 \mathrm{~g}$, soil X $\underline{0.200 \mathrm{mg} U(\mathrm{VI})}=85.58 \mathrm{mg}, \mathrm{U}(\mathrm{VI})$

$$
\text { g, soil }
$$

$\% \cup$ leached from soil $=$

Total U leached from soil $\times 100=59.46 \mathrm{mg} \times 100=69.5 \%$

Total U(VI) added to soil $\quad 85.58 \mathrm{mg}$ 
TEST \#4 (3-0747)

In this test, a sample of Hanford Site soil was contaminated to $200 \mathrm{ppm}$ with $\mathrm{U}(\mathrm{VI})$, treated with $2000 \mathrm{ppm} \mathrm{H} \mathrm{H}_{2}$, and leached with groundwater from the Hanford Site unconfined aquifer. A total of 37.85 $\mathrm{mg}$ of uranium was leached from $423.37 \mathrm{grams}$ of soil. This corresponds to $44.7 \%$ of the uranium added to the soil.

Note: Leachate samples were weighed and converted to $\mathrm{mLs}$ based on assumption that $1 \mathrm{~mL}=1$ gram.

\begin{tabular}{||l|l|l|l||}
\hline $\begin{array}{l}\text { \# COLUMN } \\
\text { PORE VOLUMES }\end{array}$ & $\begin{array}{l}\text { LEACHATE } \\
\text { VOLUME, } \mathrm{mLs}\end{array}$ & $\mathrm{U}, \mathrm{mg} / \mathrm{L}$ & $\mathrm{U}, \mathrm{mg}$ \\
\hline \hline $0.00-1.35$ & 137.38 & 124 & 17.04 \\
\hline $1.35-2.37$ & 104.23 & 47.8 & 4.98 \\
\hline $2.37-3.43$ & 107.61 & 41.4 & 4.46 \\
\hline $3.43-6.49$ & 311.57 & 36.5 & 11.37 \\
\hline \multicolumn{4}{|c|}{ Total $\mathrm{N}=37.85 \mathrm{mg}$} \\
\hline
\end{tabular}

Total $\mathrm{U}(\mathrm{VI})$ added to soil $=$

$423.37 \mathrm{~g}$, soil $X \underline{0.200 \mathrm{mg} U(V I)}=84.67 \mathrm{mg}, U(V I)$

g, soil

$\% \cup$ leached from soil $=$

Total U leached from soil $\times 100=37.85 \mathrm{mg} \times 100=44.7 \%$

Total U(VI) added to soil $\quad 84.67 \mathrm{mg}$ 
In this test, a sample of Hanford Site soil was contaminated to $200 \mathrm{ppm}$ with U(VI), treated with $100 \mathrm{ppm} \mathrm{H}_{2} \mathrm{~S}$, and leached with groundwater from the Hanford Site unconfined aquifer. A total of 26.50 $\mathrm{mg}$ of uranium was leached from 403.25 grams of soil. This corresponds to $32.9 \%$ of the uranium added to the soil.

Note: Leachate samples were weighed and converted to $\mathrm{mLs}$ based on assumption that $1 \mathrm{~mL}=1$ gram.

\begin{tabular}{||l|l|l|l||}
\hline \hline $\begin{array}{l}\text { \# COLUMN } \\
\text { PORE VOLUMES }\end{array}$ & $\begin{array}{l}\text { LEACHATE } \\
\text { VOLUME, } \mathrm{mLs}\end{array}$ & $\mathrm{U}, \mathrm{mg} / \mathrm{L}$ & $U, \mathrm{mg}$ \\
\hline \hline $0.00-0.76$ & 78.46 & 78.2 & 6.14 \\
\hline $0.76-1.73$ & 99.98 & 52.2 & 5.22 \\
\hline $1.73-2.72$ & 102.39 & 46.8 & 4.79 \\
\hline $2.72-5.58$ & 294.77 & 35.1 & 10.35 \\
\hline
\end{tabular}

Total U(VI) added to soil $=$

$403.25 \mathrm{~g}$, soil $X \underline{0.200 \mathrm{mg} \mathrm{U}(\mathrm{VI})}=80.65 \mathrm{mg}, \mathrm{U}(\mathrm{VI})$

$$
\text { g, soil }
$$

$\% \cup$ leached from soil $=$

Total U leached from soil $\times 100=\underline{26.50 \mathrm{mg}} \times 100=32.9 \%$

Total $U(V I)$ added to soil $\quad 80.65 \mathrm{mg}$ 


\section{TEST \#6 (3-0749)}

In this test, a sample of Hanford Site soil was contaminated to $200 \mathrm{ppm}$ with U(VI) plus $5000 \mathrm{ppm}$ $\mathrm{NO}_{3}{ }^{-}$and $200 \mathrm{ppm} \mathrm{Cr}(\mathrm{VI})$. It was then treated with $2000 \mathrm{ppm} \mathrm{H} \mathrm{H}_{2} \mathrm{~S}$ and leached with groundwater from the Hanford Site unconfined aquifer. A total of $37.69 \mathrm{mg}$ of uranium was leached from 423.28 grams of soil. This corresponds to $44.5 \%$ of the uranium added to the soil.

Note: Leachate samples were weighed and converted to $\mathrm{mLs}$ based on assumption that $1 \mathrm{~mL}=1$ gram.

\begin{tabular}{||l|l|l|l||}
\hline $\begin{array}{l}\text { \# COLUMN } \\
\text { PORE VOLUMES }\end{array}$ & $\begin{array}{l}\text { LEACHATE } \\
\text { VOLUME, } \mathrm{mLs}\end{array}$ & $\mathrm{U}, \mathrm{mg} / \mathrm{L}$ & $\mathrm{U}, \mathrm{mg}$ \\
\hline \hline $0.00-1.47$ & 105.91 & 131 & 13.87 \\
\hline $1.47-2.54$ & 109.11 & 102 & 11.13 \\
\hline $2.54-3.63$ & 112.56 & 44.3 & 4.99 \\
\hline $3.63-6.79$ & 323.69 & 23.8 & 7.70 \\
\hline
\end{tabular}

Total $U(V I)$ added to soil $=$

$423.28 \mathrm{~g}$, soil $X \underline{0.200 \mathrm{mg} U(V I)}=84.66 \mathrm{mg}, U(V I)$

g, soil

$\%$ U leached from soil $=$

Total U leached from soil $\times 100=37.69 \mathrm{mg} \times 100=44.5 \%$

Total U(VI) added to soil $\quad 84.66 \mathrm{mg}$ 
TEST \#7 (3-0750)

In this test, a sample of Hanford Site soil was contaminated to $200 \mathrm{ppm}$ with U(VI) plus $5000 \mathrm{ppm}$ $\mathrm{NO}_{3}{ }^{-}$and $200 \mathrm{ppm} \mathrm{Cr}(\mathrm{VI})$. It was then treated with $100 \mathrm{ppm} \mathrm{H}_{2} \mathrm{~S}$ and leached with groundwater from the Hanford Site unconfined aquifer. A total of $38.95 \mathrm{mg}$ of uranium was leached from 430.32 grams of soil. This corresponds to $45.3 \%$ of the uranium added to the soil.

Note: Leachate samples were weighed and converted to $\mathrm{mLs}$ based on assumption that $1 \mathrm{~mL}=1$ gram.

\begin{tabular}{||l|l|l|l||}
\hline \hline $\begin{array}{l}\text { \# COLUMN } \\
\text { PORE VOLUMES }\end{array}$ & $\begin{array}{l}\text { LEACHATE } \\
\text { VOLUME, } \mathrm{mLs}\end{array}$ & $\mathrm{U}, \mathrm{mg} / \mathrm{L}$ & $\mathrm{U}, \mathrm{mg}$ \\
\hline \hline $0.00-1.13$ & 108.66 & 86.6 & 9.41 \\
\hline $1.13-2.11$ & 94.89 & 138 & 13.09 \\
\hline $2.11-3.12$ & 97.20 & 77.2 & 7.50 \\
\hline $3.12-6.01$ & 278.01 & 32.2 & 8.95 \\
\hline
\end{tabular}

Total U(VI) added to soil $=$

$430.32 \mathrm{~g}$, soil $\times \underline{0.200 \mathrm{mg} U(V \mathrm{l})}=86.06 \mathrm{mg}, \mathrm{U}(\mathrm{Vl})$

$$
\text { g, soil }
$$

$\%$ U leached from soil $=$

Total U leached from soil $\times 100=\underline{38.95 \mathrm{mg} \times 100=45.3 \%}$

Total U(VI) added to soil $\quad 86.06 \mathrm{mg}$ 
TEST \#13 (3-0756)

In this test, a sample of uncontaminated Fernald soil was leached with deionized water. The concentration of total leachable uranium in the soil sample was approximately $22 \mathrm{ppb}$.

Note: Leachate samples were weighed and converted to $\mathrm{mLs}$ based on assumption that $1 \mathrm{~mL}=1$ gram.

\begin{tabular}{|l|l|l|l||}
\hline $\begin{array}{l}\text { \# COLUMN } \\
\text { PORE VOLUMES }\end{array}$ & $\begin{array}{l}\text { LEACHATE } \\
\text { VOLUME, } \mathrm{mLs}\end{array}$ & $\mathrm{U}, \mathrm{mg} / \mathrm{L}$ & $\mathrm{U}, \mathrm{mg}$ \\
\hline \hline $0.00-0.98$ & 153.30 & 0.0481 & 0.007 \\
\hline $0.98-2.02$ & 142.16 & 0.00117 & 0.000 \\
\hline $2.02-3.09$ & 145.09 & $<0.00098$ & 0.000 \\
\hline $3.09-6.36$ & 445.35 & 0.00035 & 0.000 \\
\hline
\end{tabular}

Sample wt $=324.16 \mathrm{~g}$

Concentration of total leachable uranium in soil $=$

$\frac{\text { Total } U}{\text { sample wt }}=\frac{0.007 \mathrm{mg} \mathrm{U}}{324.16 \mathrm{~g} \text {, soil }}=0.022 \frac{\mathrm{mg}}{\mathrm{kg}}$ or $22 \mathrm{ppb} U$ 
TEST \#14 (3-0757)

In this test, a sample of uncontaminated Fernald soil was treated with $2000 \mathrm{ppm} \mathrm{H}_{2} \mathrm{~S}$ and leached with deionized water. The concentration of total leachable uranium in the soil sample was about $70 \mathrm{ppb}$.

Note: Leachate samples were weighed and converted to $\mathrm{mLs}$ based on assumption that $1 \mathrm{~mL}=1$ gram.

\begin{tabular}{||l|l|l|l||}
\hline $\begin{array}{l}\text { \# COLUMN } \\
\text { PORE VOLUMES }\end{array}$ & $\begin{array}{l}\text { LEACHATE } \\
\text { VOLUME, } \mathrm{mLs}\end{array}$ & $\mathrm{U}, \mathrm{mg} / \mathrm{L}$ & $\mathrm{U}, \mathrm{mg}$ \\
\hline \hline $0.00-1.07$ & 150.09 & 0.105 & 0.016 \\
\hline $1.07-1.97$ & 125.57 & 0.0344 & 0.004 \\
\hline $1.97-2.83$ & 120.62 & 0.00933 & 0.001 \\
\hline $2.83-5.57$ & 383.09 & $<0.00588$ & $<0.002$ \\
\hline
\end{tabular}

Sample wt $=329.47 \mathrm{~g}$

Concentration of total leachable uranium in soil $=$

$\frac{\text { Total } \mathrm{U}}{\text { sample wt }}-\frac{0.023 \mathrm{mg} \mathrm{Cr}}{329.47 \mathrm{~g} \text {, soil }}-0.070 \frac{\mathrm{mg}}{\mathrm{kg}}$ or $70 \mathrm{ppb} \mathrm{U}$ 
TEST \#15 (3-0758)

In this test, a sample of Fernald soil was contaminated to $200 \mathrm{ppm}$ with $U(\mathrm{VI})$ plus $200 \mathrm{ppm} \mathrm{Cr}(\mathrm{VI})$ and leached with deionized water. A total of $1.01 \mathrm{mg}$ of uranium was leached from 320.95 grams of soil. This corresponds to $1.6 \%$ of the uranium added to the soil.

Note: Leachate samples were weighed and converted to $\mathrm{mLs}$ based on assumption that $1 \mathrm{~mL}=1$ gram.

\begin{tabular}{||l|l|l|l||}
\hline \hline $\begin{array}{l}\text { \# COLUMN } \\
\text { PORE VOLUMES }\end{array}$ & $\begin{array}{l}\text { LEACHATE } \\
\text { VOLUME, mLs }\end{array}$ & $\mathrm{U}, \mathrm{mg} / \mathrm{L}$ & $\mathrm{U}, \mathrm{mg}$ \\
\hline \hline $0.00-0.66$ & 90.02 & 5.85 & 0.527 \\
\hline $0.66-1.55$ & 120.09 & 1.67 & 0.201 \\
\hline $1.55-2.45$ & 121.58 & 0.80 & 0.097 \\
\hline $2.45-4.96$ & 340.48 & 0.54 & 0.184 \\
\hline
\end{tabular}

Total $\mathrm{U}(\mathrm{VI})$ added to soil $=$

$320.95 \mathrm{~g}$, soil $X \underline{0.200 \mathrm{mg} U(\mathrm{VI})}=64.19 \mathrm{mg}, \mathrm{U}(\mathrm{VI})$

g, soil

$\% \cup$ leached from soil $=$

Total U leached from soil $\times 100=1.01 \mathrm{mg} \times 100=1.6 \%$

Total U(VI) added to soil $\quad 64.19 \mathrm{mg}$ 
TEST \#16 (3-0759)

In this test, a sample of Fernald soil was contaminated to $200 \mathrm{ppm}$ with U(VI) plus $200 \mathrm{ppm}$ $\mathrm{Cr}(\mathrm{VI})$. It was then treated with $2000 \mathrm{ppm} \mathrm{H}_{2} \mathrm{~S}$ and leached with deionized water. A total of about 3.19 $\mathrm{mg}$ of uranium was leached from 323.93 grams of soil. This corresponds to $4.9 \%$ of the uranium added to the soil.

Note: Leachate samples were weighed and converted to $\mathrm{mLs}$ based on assumption that $1 \mathrm{~mL}=1$ gram.

\begin{tabular}{||l|l|l|l||}
\hline $\begin{array}{l}\text { \# COLUMN } \\
\text { PORE VOLUMES }\end{array}$ & $\begin{array}{l}\text { LEACHATE } \\
\text { VOLUME, } \mathrm{mLs}\end{array}$ & $\mathrm{U}, \mathrm{mg} / \mathrm{L}$ & $\mathrm{U}, \mathrm{mg}$ \\
\hline \hline $0.00-0.69$ & 93.73 & 11.3 & 1.059 \\
\hline $0.69-1.59$ & 122.35 & 8.97 & 1.097 \\
\hline $1.59-2.51$ & 124.60 & 3.64 & 0.454 \\
\hline $2.51-5.08$ & 349.57 & 1.66 & 0.580 \\
\hline \multicolumn{4}{|c|}{ Total $\mathrm{U}=3.19 \mathrm{mg}$} \\
\hline
\end{tabular}

Total U(VI) added to soil $=$

$323.93 \mathrm{~g}$, soil $X \underline{0.200 \mathrm{mg} U(V I)}=64.79 \mathrm{mg}, U(V I)$

g, soil

$\% \cup$ leached from soil $=$

Total U leached from soil $\times 100=3.19 \mathrm{mg} \times 100=4.9 \%$

Total U(VI) added to soil $\quad \frac{3.19 \mathrm{mg}}{64.79 \mathrm{mg}}$ 
TEST \#17 (3-0760)

In this test, a sample of Fernald soil was contaminated to $200 \mathrm{ppm}$ with U(VI) plus $200 \mathrm{ppm}$ $\mathrm{Cr}(\mathrm{VI})$. It was then treated with $100 \mathrm{ppm} \mathrm{H}_{2} \mathrm{~S}$ and leached with deionized water. A total of about 0.98 $\mathrm{mg}$ of uranium was leached from 320.80 grams of soil. This corresponds to $1.5 \%$ of the uranium added to the soil.

Note: Leachate samples were weighed and converted to $\mathrm{mLs}$ based on assumption that $1 \mathrm{~mL}=1$ gram.

\begin{tabular}{||l|l|l|l||}
\hline $\begin{array}{l}\text { \# COLUMN } \\
\text { PORE VOLUMES }\end{array}$ & $\begin{array}{l}\text { LEACHATE } \\
\text { VOLUME, mLs }\end{array}$ & $\mathrm{U}, \mathrm{mg} / \mathrm{L}$ & $U, \mathrm{mg}$ \\
\hline \hline $0.00-0.60$ & 79.19 & 3.5 & 0.277 \\
\hline $0.60-1.55$ & 124.69 & 1.88 & 0.234 \\
\hline $1.55-2.52$ & 127.32 & 1.55 & 0.197 \\
\hline $2.52-5.23$ & 356.44 & 0.77 & 0.274 \\
\hline
\end{tabular}

Total $\mathrm{U}(\mathrm{VI})$ added to soil $=$

$320.80 \mathrm{~g}$, soil $X \underline{0.200 \mathrm{mg} U(V))}=64.16 \mathrm{mg}, \mathrm{U}(\mathrm{VI})$

g, soil

$\%$ U leached from soil $=$

Total U leached from soil $\times 100=0.98 \mathrm{mg} \times 100=1.5 \%$

Total U(VI) added to soil $\quad 64.16 \mathrm{mg}$ 
"In this test, a sample of Hanford Site soil was contaminated to $200 \mathrm{ppm}$ with U(VI) plus $200 \mathrm{ppm}$ $\mathrm{Cr}(\mathrm{VI})$ and air dryed to a moisture content of $0.88 \%$. The soil was then treated with $2000 \mathrm{ppm} \mathrm{H}_{2} \mathrm{~S}$, and leached with groundwater from the Hanford Site unconfined aquifer. A total of $37.43 \mathrm{mg}$ of uranium was leached from 422.40 grams of soil. This corresponds to $44.3 \%$ of the uranium added to the soil.

Note: Leachate samples were weighed and converted to $\mathrm{mLs}$ based on assumption that $1 \mathrm{~mL}=1$ gram.

\begin{tabular}{||l|l|l|l||}
\hline $\begin{array}{l}\text { \# COLUMN } \\
\text { PORE VOLUMES }\end{array}$ & $\begin{array}{l}\text { LEACHATE } \\
\text { VOLUME, } \mathrm{mLs}\end{array}$ & $\mathrm{U}, \mathrm{mg} / \mathrm{L}$ & $\mathrm{U}, \mathrm{mg}$ \\
\hline \hline $0.00-1.38$ & 132.33 & 40.6 & 5.37 \\
\hline $1.38-2.79$ & 136.32 & 56.3 & 7.67 \\
\hline $2.79-4.24$ & 138.97 & 52.3 & 7.27 \\
\hline $4.24-8.29$ & 389.14 & 44.0 & 17.12 \\
\hline
\end{tabular}

Total $\mathrm{U}(\mathrm{VI})$ added to soil $=$

$422.40 \mathrm{~g}$, soil $X \underline{0.200 \mathrm{mg} \mathrm{U}(V \mathrm{l})}=84.48 \mathrm{mg}, \mathrm{U}(\mathrm{VI})$

g, soil

$\% \cup$ leached from soil $=$

Total U leached from soil $\times 100=37.43 \mathrm{mg} \times 100=44.3 \%$

Total U(VI) added to soil $\quad 84.48 \mathrm{mg}$ 
TEST \#19 (3-0762)

In this test, a sample of Hanford Site soil was contaminated to $200 \mathrm{ppm}$ with U(VI) plus $200 \mathrm{ppm}$ $\mathrm{Cr}(\mathrm{VI})$ and additional water was added to attain a moisture content of $9.70 \%$. The soil was then treated with $2000 \mathrm{ppm} \mathrm{H} \mathrm{H}_{2} \mathrm{~S}$, and leached with groundwater from the Hanford Site unconfined aquifer. A total of $37.06 \mathrm{mg}$ of uranium was leached from 457.50 grams of soil. This corresponds to $40.5 \%$ of the uranium added to the soil.

Note: Leachate samples were weighed and converted to $\mathrm{mLs}$ based on assumption that $1 \mathrm{~mL}=1$ gram.

\begin{tabular}{||l|l|l|l||}
\hline $\begin{array}{l}\text { \# COLUMN } \\
\text { PORE VOLUMES }\end{array}$ & $\begin{array}{l}\text { LEACHATE } \\
\text { VOLUME, } \mathrm{mLs}\end{array}$ & $\mathrm{U}, \mathrm{mg} / \mathrm{L}$ & $\mathrm{U}, \mathrm{mg}$ \\
\hline \hline $0.00-1.71$ & 158.40 & 74.9 & 11.86 \\
\hline $1.71-3.12$ & 130.92 & 50.6 & 6.62 \\
\hline $3.12-4.55$ & 133.44 & 42.0 & 5.60 \\
\hline $4.55-8.57$ & 372.97 & 34.8 & 12.98 \\
\hline
\end{tabular}

Total U(VI) added to soil $=$

$457.50 \mathrm{~g}$, soil $X \underline{0.200 \mathrm{mg} \mathrm{U}(\mathrm{VI})}=91.50 \mathrm{mg}, \mathrm{U}(\mathrm{VI})$

g, soil

$\% \cup$ leached from soil $=$

Total U leached from soil $\times 100=37.06 \mathrm{mg} \times 100=40.5 \%$

Total U(VI) added to soil $\quad 91.50 \mathrm{mg}$ 


\section{DISTRIBUTION}

\section{Number of Copies}

\section{OFFSITE}

12

64
DOE Office of Scientific and Technical Information

U.S. Department of Energy 12800 Middlebrook Road Germantown, MD 20874

T.D. Anderson

EM-551

K.J. Angleberger

EM-442

S.B. Balone

J.E. Baublitz

C.O. Bauer

P.M. Beam

H. Belencan

D.L. Biancosino

J.O. Boda

G.G. Boyd

E. Carrell

S.H. Chamberlain

K-C. Chang

K.A. Chaney

J.A. Coleman

S.P. Cowan

T.M. Crandall

J.J. Fiore

C.W. Frank

D.W. Geiser

K. Gerdes

S.M. Gibson

M.A. Godin

L. Harmon

M.T. Janaskie

R.A. Jump

M.J. Lankford

R.S. Levine

S.C. Lien

R.G. Lightner

S.A. Mann

C.B. Purdy

W.C. Schutte

D.S. Shafer

M.W. Shupe
EM-442

EM-40

EM-441

EM-451

EM-453

EM-551

EM-322

EM-53

EM-352

EM-551

EM-352

EM-424

EM-35

EM-30

EM-451

EM-42

EM-50

EM-523

EM-551

EM-55

EM-36

EM-32

EM-40

EM-441

EM-55

EM-54

EM-54

EM-45

EM-44

EM-542

EM-54

EM-452

EM-541 
Number of Copies

U.S. Department of Energy

12800 Middlebrook Road (continued)

C.H. Sink

EM-521

R.L. Sweeney

EM-323

M. Steele

$\mathrm{EH}-30$

L.H. Taylor

EM-43

M.M. Torbert

EM-321

J.S. Walker (20)

EM-54

H.F. Walter

EM-343

S.W. Warren

EM-442

S.M. Wolf

EM-542

2

U.S. Department of Energy

Forrestal Building

1000 Independence Ave SW

Washington, D.C. 20585

W. Bixby

$E M-60$

L.W. Smith

$E M-60$

4

U.S. Department of Energy

19901 Germantown Rd

Germantown, MD 20874

D.J. Grimes

ER-74

G.Y. Jordy

ER-30

A. Patrinos

ER-74

F.J. Wobber

ER-75

4

U.S. Department of Energy

Morgantown Energy Tech. Center

P.O. Box 880

3610 Collins Ferry Road

Morgantown, WV 26507-0880

R.C. Bedick

S.J. Bossart

T. Martin

C. Zeh 
Number of Copies

5

1

2

2

2
U.S. Department of Energy

Albuquerque Operations Office

P.O. Box 5400

Albuquerque, NM 87115

C.W. Bethany

K. Douglas

D.A. Olana

J. Orban

P.A. Saxman

U.S. Department of Energy

Amarillo Area Office

Highway 60 FM 2373

Pantex Plant

Amarillo, TX 79120

T. Taylor

U.S. Department of Energy Chicago Operations Office 9800 S. Cass Avenue

Argonne, IL 60439

R. Baker

S. Webster

U.S. Department of Energy

Fernald Area Office

P.O. Box 389705

Cincinnati, $\mathrm{OH} \quad 45239-8705$

B.P. Shroff

R. Warnèr

U.S. Department of Energy

Idaho Operations Office

785 DOE Place

Idaho Falls, ID 83402

N.S. Burrell

T.E. Williams 
Number of Copies

2

1

1

1

3

3

U.S. Department of Energy

Nevada Operations Office

P.O. Box 98518

Las Vegas, NV 89193-8518

K. McWilliam

R.F. Smiecinski

U.S. Department of Energy

Oak Ridge Operations Office

P.O. Box 2001

Oak Ridge, TN 37831

J. Moore

U.S. Department of Energy Oakland Operations Office 1333 Broadway

Oakland, CA 94612

R. Scott

U.S. Department of Energy

Pittsburgh Energy Tech. Center

P.O. Box 10940

Cochran's Mill Road

Pittsburgh, PA 15236-0940

G.E. Staats

U.S. Department of Energy

Rocky Flats Operations Office

P.O. Box 928, Highway 93

Golden, CO 80402-0928

S. Grace

S. Rudolph

J.D. Steward

U.S. Department of Energy

Savannah River Operations Office

P.O. Box A

Aiken, SC 29808

A.A. Blackman

J.R. Patterson

M. O'Rear 
Number of Copies

2

6

1

2

2

1
Ames Laboratory 329 Wilhelm Hall

lowa State University

Ames, IA 50011

W. Haas

P. Wang

Argonne National Laboratory 9700 S. Cass Avenue Argonne, IL 60439-4837

N. Beskid

J.C. Cunnane

J. Frank

J.E. Helt

D. Johnsón

R.W. Peters

Dr. John Benemann

343 Caravell Dr

Walnut Creek, CA 94598

Bradtec - U.S., Inc.

1010 Huntcliff Tr, Suite 1350

Atlanta, GA 30350

N. Swift

M. Dunn

Brookhaven National Laboratory

Building $\cdot 703-50$ Rutherford

Upton, NY 11973

J. Heiser

P. Colombo

Colorado Center for Environmental Mgmt. 1536 Cole Blvd.

Bldg. 4, Suite 180

Golden, CO 80401

D. Kaback 
Number of Copies

1

1

1

1

3
DuPont Research \& Development

P.O. Box 80304

Wilmington, DE 19880-0304

C.T. Sciance

EG\&G Idaho, Inc.

Idaho National Engineering Laboratory

P.O. Box 1625

Idaho Falls, ID 83415

S. Brown

K. M. Kostelnik

R. Kuhl

D. Mairs

K. Merrill

P. Wichlacz

EG\&G Rocky Flats, Inc.

Technology Development

P.O. Box 464

Golden, $\mathrm{CO} 80402$

\section{J.L. Peterson}

EG\&G Energy Measurement, Inc.

P.O. Box 1912

Las Vegas, NV 89125

L. Rogers

MS RLS-11

Enserch Environmental Corp. 1981 Snyder Road, Suite 3

Richland, WA 99352

R. Treat .

Fernald Environmental Mgmt. Company of Ohio P.O. Box 398704

Cincinnati, $\mathrm{OH}$ 45239-8704

K. Nuhfer

P.J. Pettit

D.E. Ridenour 
Number of Copies

1

3

3

5

5
Golder Federal Services, Inc. 4104 148th Avenue NE

Redmond, WA 98502

C. Voss

Hazen and Sawyer, P.C. 4011 West Chase Blvd.

Raleigh, NC 27607

G. Richardson

HAZWRAP

P.O. Box 2003

Oak Ridge, TN 37831-7606

R.E. Adams

R. Snipes

R. Swatzell

Lawrence Berkeley Laboratory

1 Cyclotron Road

Berkeley, CA 94720

C-F. Tsang

G. Moridis

K. Pruess

Lawrence Livermore National Laboratory

P.O. Box 808

Livermore, CA 94550

D. Bishop

A.C Heywood

R.B. Knapp

D. Rice

J.L. Yow

Los Alamos National Laboratory

P.O. Box 1663

Los Alamos, NM 87545

B.R. Erdal

D. Janecky

T.E. Hakonson

H.D. Murphy

J. Turin 


\section{Number of Copies}

1

2

16

1

3
Massachusetts Institute of Technology

Plasma Fusion Center

167 Albany Street, NW16-140

Cambridge, MA 02139

\section{R.F. Probstein}

MSE, Inc.

P.O. Box 4078

Butte, MT 59702

N.S. Egan

W.C. Goldberg

Oak Ridge National Laboratory

P.O. Box 2008

Oak Ridge, TN 37831-6273

J. Berry

T. Donaldson

T. Early

B. Faison

D. Gates

S.E. Herbes

R. Jenkins

K. Kibbe

K.T. Klasșon

J. Koger

A. Malinauskas

A.V. Palumbo

T. Phelps

$M$. Reeves

J. Strong-Gunderson

R.L. Siegrist

Oregon State University

Dept. of Civil Engineering

Corvallis, OR 97331-2302

L. Semprini

RUST Geotech Inc.

P.O. Box 14000

Grand Junction, CO 81502-2567

D. Emilia

S.J. Morrison

S. Schweissing 
Number of Copies

1

6

2

2

4

1
SAIC Rocky Flats Plant

P.O. Box 928

Golden, CO 80402-0464

T.C. Greengard

Sandia National Laboratories

P.O. Box 5800

Albuquerque, NM 87185

G. Allen

E.R. Lindgren

J. Phelan

R. Matalucci

J. Nelson

J. Stormont

Stanford University

Stanford, CA 94305-4020

P. Kitanidis

P. McCarty

U.S. Air Force

Tyndall AFB, FL 32403-6001

J. Spain

K. Vogel

HQ AFCESARAVW

U.S. Environmental Protection

Agency

W. Martin Luther King Dr.

Cincinnati, $\mathrm{OH} 45268$

E.F. Barth

J. Martin

R. Parker.

M. Roulier

U.S. Environmental Protection

Agency

1 Sabine Island Dr.

Gulf Breeze, FL 32561-5299

H. Pritchard 


\section{Number of Copies}

1

U.S. Environmental Protection

Agency

712 Swift Blvd, Suite 5

Richland, WA 99352

D.R. Sherwood

1

U.S. Environmental Protection

\section{Agency}

Region 10 - ES-098

1200 Sixth Avenue

Seattle, WA 98101

J. Barich

U.S. Environmental Protection

Agency

$401 \mathrm{M}$ Street, SW

Washington, D.C.

D.M. Powell

1

University of Idaho

106 Morrill Hall

Moscow, ID 83843

R. Mink

University of Texas

Dept. of Civil Engineering

26th St. at San Jacinto, ECJ 9.227

Austin, TX 78712-1076

D.E. Daniel

Westinghouse Savannah River Co.

Savannah River Site

Aiken, SC 29808

J. Bibler

T. Coleman

J. Haselow

T.C. Hazen

K. Jerome

B. Looney

J. Steele 
Number of Copies

1

ONSITE

4

12

1

50
WINCO, Inc.

P.O. Box 4000, MS 3211

Idaho Falls, ID 83415-3211

L.W. McClure
$\mathrm{H} 4-79$

H6-01

H6-06

H6-05

R.L. Jackson

J.G. Woolard

DOE-Richland Operations

D.A. Brown

K8-50

R.F. Brich

S.T. Burnum

J.K. Erickson

L. Erickson

R.D. Freeberg

J.D. Goodenough

J.M. Hennig

L. Mamiya

B. L. Nicoll

R.K. Stewart

D.E. Trader

Kaiser Engineers Hanford Co.

H.A. Dugger

Westinghouse Hanford Company

M.R. Adams

H. Babad

M.A. Baechler (3)

M.A. Beck (3)

H.L. Benny

J.D. Berger

G.T. Berlin

L.C. Brown
E6-64

H6-01

A5-19

R3-74

A5-19

R3-74

A5-19

A4-19

R3-80

K8-50

R3-74

A5-19

K8-50

R2-78

L7-09

T6-09

L5-64

LO-18

LO-18

H6-28 
Number of Copies

40
Westinghouse Hanford Company Continued

J.W. Cammann

H414

R.A. Evans

$\mathrm{H} 0-31$

L5-63

R2-52

H.D. Harmon

R2-52

J.O. Honeyman

H6-06

D.G. Horton

T6-09

B3-63

H6-06

H6-06

$\mathrm{H} 4-14$

H6-06

$\mathrm{H} 0-30$

L8-15

L8-04

H4-17

Information Release Administration (3)

K6-82

P7-41

B 1-40

P7-35

K6-81

K6-96

P8-38

BSRC

P7-41

K2-47

L5-63

K1-73

K6-81

B $1-40$

P7-41

K1-19

BSRC

P7-34

K2-44 